\title{
EFEITO DA IRRIGAÇÃO COM EFLUENTE DE ESGOTO TRATADO, RICO EM SÓDIO, EM PROPRIEDADES QUÍMICAS E FÍSICAS DE UM ARGISSOLO VERMELHO DISTRÓFICO CULTIVADO COM CAPIM-TIFTON 85
}

\section{Alex Paulus Ribeiro Dos Santos}

Dissertação apresentada à Escola Superior de Agricultura "Luiz de Queiroz", Universidade de São Paulo, para obtenção do título de Mestre em Agronomia, Área de Concentração: Solos e Nutrição de Plantas.

P I R A C I C A B A

Estado de São Paulo - Brasil

Fevereiro - 2004 


\title{
EFEITO DA IRRIGAÇÃO COM EFLUENTE DE ESGOTO TRATADO, RICO EM SÓDIO, EM PROPRIEDADES QUÍMICAS E FÍSICAS DE UM ARGISSOLO VERMELHO DISTRÓFICO CULTIVADO COM CAPIM-TIFTON 85
}

\author{
Alex Paulus Ribeiro Dos Santos \\ Engenheiro Agrônomo
}

Orientadora: Prof. Dra. CÉLIA REGINA MONTES

Dissertação apresentada à Escola Superior de Agricultura "Luiz de Queiroz", Universidade de São Paulo, para obtenção do título de Mestre em Agronomia, Área de Concentração: Solos e Nutrição de Plantas.

P I R A C I C A B A

Estado de São Paulo - Brasil

Fevereiro - 2004 
Dados Internacionais de Catalogação na Publicação (CIP) DIVISÃO DE BIBLIOTECA E DOCUMENTAÇÃO - ESALQ/USP

\section{Santos, Alex Paulus Ribeiro dos}

Efeito da irrigação com efluente de esgoto tratado ,rico em sódio, em propriedades químicas e físicas de um argissolo vermelho distrófico cultivado com capim-Tifton 85 / Alex Paulus Ribeiro dos Santos. - - Piracicaba, 2004.

79 p. : il.

Dissertação (mestrado) - - Escola Superior de Agricultura Luiz de Queiroz, 2004.

Bibliografia.

1. Água residuária 2. Capim Tifton 3. Efluente de esgoto 4. Irrigação 5. Propriedades físicoquímica 6 . Solo salino-sódico I. Título

CDD 631.416

"Permitida a cópia total ou parcial deste documento, desde que citada a fonte - O autor" 
Aos meus queridos pais

José e Merçodí,

e à minha querida irmã Eliane,

pelo amor, pelo carinho, pela presença e pela extraordinária força que temos em buscar a felicidade

À minha família de coração

Sônia, Josias, Bianca, Flavia, Josh e Katryana

pelo carinho, pela alegria, por estarem presentes mesmo

que distantes

\section{OFEREÇO}

À minha querida esposa Tatiane

pelo amor verdadeiro, pelo constante incentivo e por estar sempre presente em todos os momentos 


\section{AGRADECIMENTOS}

- À professora Dra Célia Regina Montes pelo estímulo e orientação durante os dois anos de trabalho.

- A Escola Superior de Agricultura "Luiz de Queiroz", ao Departamento de Solos e Nutrição de Plantas e à Coordenação do Programa de Pós-graduação do departamento.

- Aos funcionários do Departamento de Solos e Nutrição de Plantas, em especial ao Dorival, Flávia, Ileusa, Luís Silva e Nancy.

- A Coordenação de Aperfeiçoamento de Pessoal de Nível Superior (CAPES) pela concessão da bolsa de estudos.

- À Companhia de Saneamento Básico do Estado de São Paulo (Sabesp), por ter contribuído para a realização deste estudo no Campo Experimental de Lins/SP.

- Ao Professor Dr. Adolpho José Melfi pela contribuição em diversas etapas deste trabalho.

- À professora Sônia M. Stefano pelo auxílio nas análises estatísticas.

- Ao Núcleo de Pesquisa em Geoquímica e Geofísica da Litosfera (Nupegel) e a todos os amigos pesquisadores e funcionários.

- Aos amigos pós-graduandos, em especial ao Cristiano Andrade, Dauton Cappi, Roberta Gloaguen e Thomas Gloaguen. 
- Ao amigo e colega de trabalho, Adriel F. Fonseca, pelo convívio e pelo importante auxílio em diversas etapas desse trabalho.

- Ao grande amigo pós-graduando Gilberto R. Domingues e a minha querida cunhada Flavia V. Carreiro por terem contribuído, com grande esforço, em algumas etapas desse trabalho.

- Aos amigos graduandos Carlo G. Cardinali, Thiago M. Steffen e Vagner V. de Almeida pelo auxílio em diversas atividades deste trabalho e por terem preservado sempre o bom humor e a responsabilidade. 


\section{SUMÁRIO}

Página

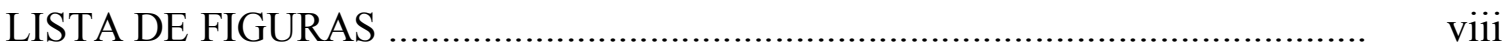

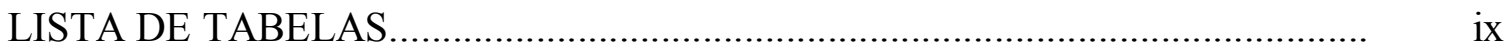

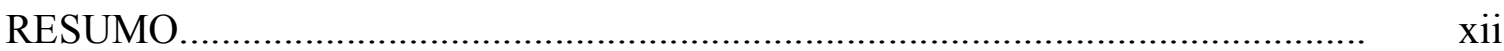

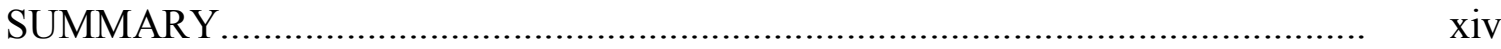

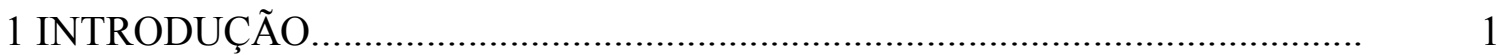

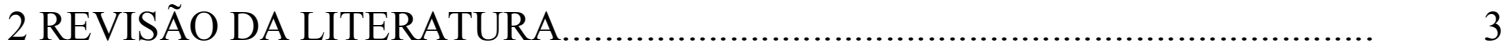

2.1 Necessidade do uso de efluentes de esgoto e de outras águas residuárias........... 3

2.2 Disposição de efluente de esgoto tratado no agrossistema................................. 5

2.2.1 Desafios para o uso agrícola de efluente de esgoto tratado............................... 9

2.2.1.1 Constituintes tóxicos, organismos patogênicos e contaminantes do ambiente...................................................................................... 10

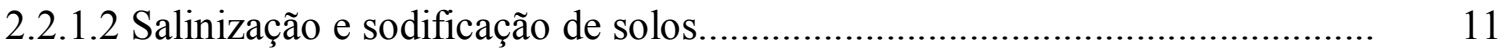

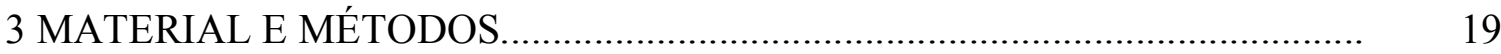

3.1 Delineamento experimental e condução do experimento.................................. 21

3.2 Coleta de amostras de água, efluente, terra, capim e obtenção da solução do solo.

3.3 Preparo de amostras e análises de água, efluente e solução do solo................... 27

3.4 Preparo de amostras e análise de terra............................................................. 28

3.5 Determinação da produção de massa seca do capim-Tifton 85 ......................... 29

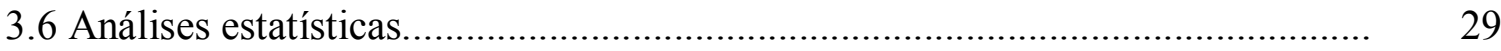

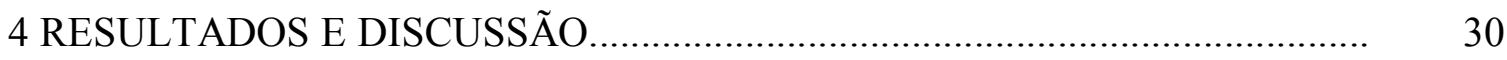

4.1 Qualidade do efluente de esgoto tratado e da água de irrigação........................ 30

4.2 Efeitos da irrigação com efluente de esgoto e com água sobre o solo................ 34

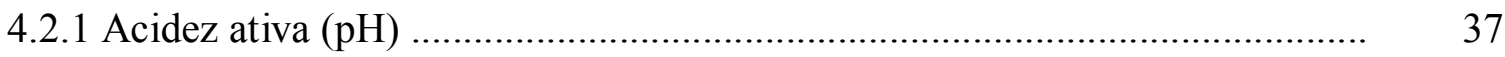

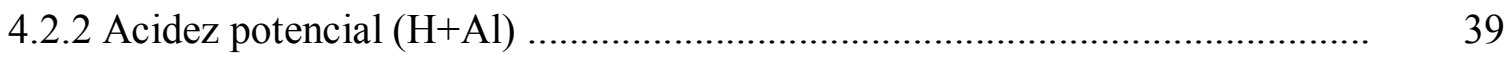


4.2.3 Teores de sódio, potássio, cálcio+magnésio e alumínio trocáveis e saturação de bases.

4.2.4 Percentual de sódio trocável (PST) ............................................................ 50

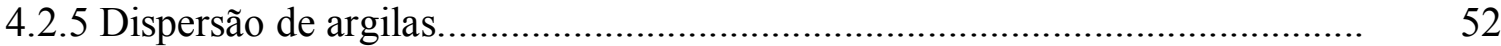

4.3 Efeito da irrigação com efluente de esgoto e com água sobre a solução do solo 55

4.3.1 $\mathrm{pH}$, condutividade elétrica (CE) e alcalinidade como bicarbonatos $\left(\mathrm{HCO}_{3}{ }^{-}\right)$. $\quad 55$

4.3.2 Concentrações de sódio, potássio, cálcio+magnésio e alumínio........................ 60

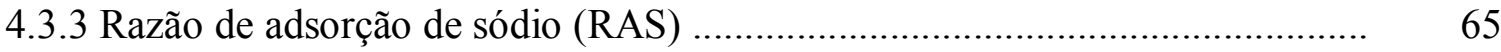

4.4 Efeito da irrigação com efluente de esgoto e com água sobre a produção de

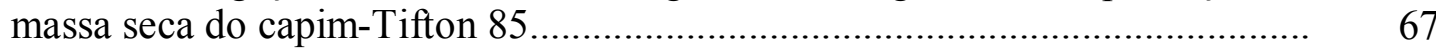

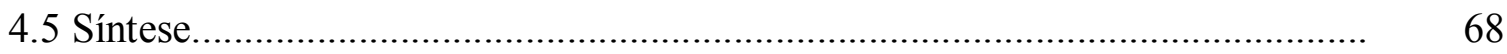

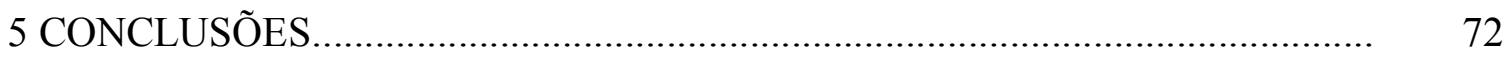

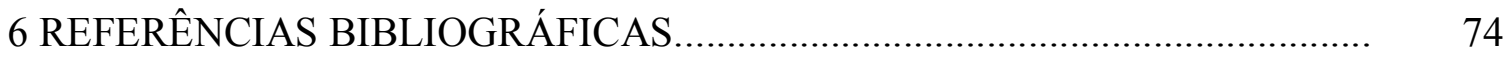




\section{LISTA DE FIGURAS}

Página

1 Classificação de solos sódicos e espécies químicas predominantes ...................... 15

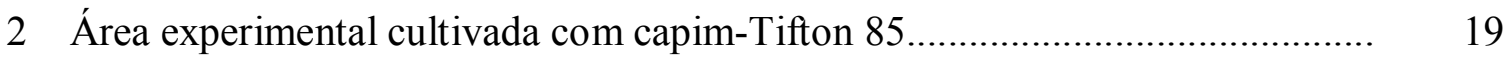

3 Lagoas de estabilização operadas pela Sabesp em Lins (SP) ........................... 20

4 Croqui do experimento indicando a distribuição dos tratamentos às parcelas

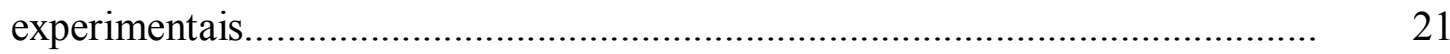

5 Localização do aspersor no centro da parcela.............................................. 24

6 Distribuição da precipitação e raio de alcance do aspersor ................................. 24

7 Conjunto de tensiômetros instalados em diferentes camadas do solo................... 25 


\section{LISTA DE TABELAS}

Página

1 Características dos efluentes domésticos secundários...................................... 6

2 Aumento de produtividade agrícola (ton ha ${ }^{-1} \mathrm{ano}^{-1}$ ) mediante a irrigação com

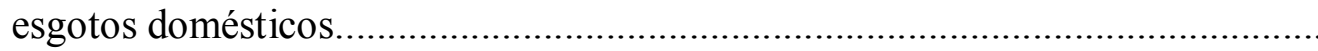

3 Quantidades de fertilizantes minerais adicionados às parcelas durante o experimento.

4 Resultados de análises químicas da água e do efluente de esgoto utilizados para irrigação do capim-Tifton de janeiro a julho de 2003

5 Graus de restrição para o uso da água e do efluente de esgoto tratado para irrigação de culturas por aspersão

6 Tolerância de capins bermuda (Cynodon dactylon) em relação à salinidade do solo (CEe) e da água de irrigação (CEa), com base no percentual de rendimento

7 Volumes de água e efluente adicionados via irrigação durante o período experimental.

8 Resultados de análise química para caracterização do solo previamente à instalação do experimento.

9 Frações granulométricas e argila dispersa em água (ADA) para caracterização do solo previamente à instalação do experimento

10 Valores de $\mathrm{pH}$ do solo em solução de $\mathrm{CaCl}_{2} 0,01 \mathrm{~mol} \mathrm{~L}^{-1}$ após irrigação com água ou efluente de esgoto nos meses de abril e julho de 2003 
11 Teores de $\mathrm{H}+\mathrm{Al}\left(\mathrm{mmol}_{\mathrm{c}} \mathrm{L}^{-1}\right)$ no solo após irrigação com água ou efluente de

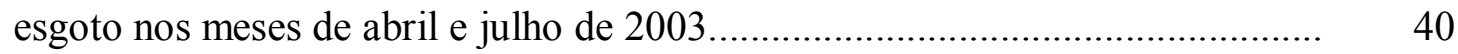

12 Teor de Na trocável $\left(\mathrm{mmol}_{\mathrm{c}} \mathrm{L}^{-1}\right)$ no solo após irrigação com água ou efluente

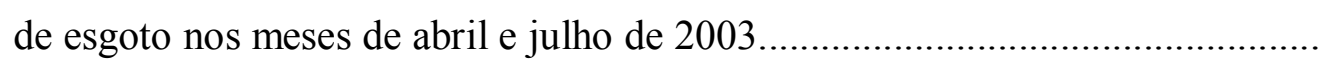

13 Teor de $\mathrm{K}$ trocável $\left(\mathrm{mmol}_{\mathrm{c}} \mathrm{L}^{-1}\right)$ no solo após irrigação com água ou efluente de esgoto nos meses de abril e julho de 2003 ........................................................

14 Teor de $\mathrm{Ca}+\mathrm{Mg}$ trocáveis $\left(\mathrm{mmol}_{\mathrm{c}} \mathrm{L}^{-1}\right)$ no solo após irrigação com água ou efluente de esgoto nos meses de abril e julho de 2003 ....................................

15 Teor de $\mathrm{Al}$ trocável $\left(\mathrm{mmol}_{\mathrm{c}} \mathrm{L}^{-1}\right)$ no solo após irrigação com água ou efluente de esgoto nos meses de abril e julho de 2003 ..................................................

16 Saturação por bases do solo (V, \%) após irrigação com água ou efluente de

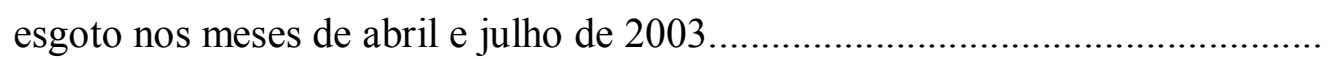

17 Percentual de sódio trocável (PST, \%) no solo após irrigação com água ou

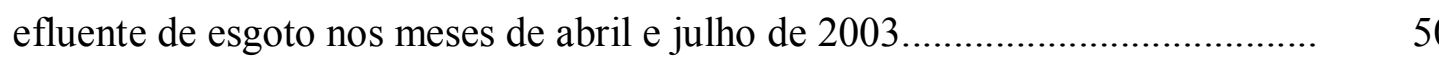

18 Grau de dispersão (GD, \%) das argilas nas camadas do solo após irrigação com água ou efluente de esgoto nos meses de abril e julho de 2003.

19 Valores de pH da solução do solo após irrigação com água ou efluente de esgoto nos meses de abril e julho de 2003.

20 Valores de condutividade elétrica $(\mathrm{CE})\left(\mathrm{dS} \mathrm{\textrm {m } ^ { - 1 }}\right)$ da solução do solo após irrigação com água ou efluente de esgoto nos meses de abril e julho de $2003 . .$.

21 Alcalinidade da solução do solo como bicarbonato $\left(\mathrm{HCO}_{3}{ }^{-}\right)\left(\mathrm{mmol}_{\mathrm{c}} \mathrm{L}^{-1}\right)$ após irrigação com água ou efluente de esgoto nos meses de abril e julho de 2003.

22. Concentração de $\mathrm{Na}$ na solução do solo $\left(\mathrm{mmol}_{\mathrm{c}} \mathrm{L}^{-1}\right)$ após irrigação com água ou efluente de esgoto nos meses de abril e julho de 2003 
23 Concentração de $\mathrm{K}$ na solução do solo $\left(\mathrm{mmol}_{\mathrm{c}} \mathrm{L}^{-1}\right)$ após irrigação com água ou efluente de esgoto nos meses de abril e julho de 2003 ...................................

24 Concentração de $\mathrm{Ca}+\mathrm{Mg}$ no solo $\left(\mathrm{mmol}_{\mathrm{c}} \mathrm{L}^{-1}\right)$ após irrigação com água ou

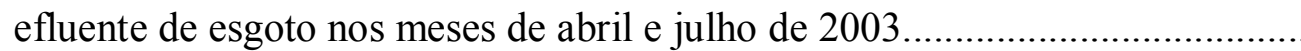

25 Razão de adsorção de sódio (RAS) $\left(\left(\operatorname{mmol}_{\mathrm{c}} \mathrm{L}^{-1}\right)^{0,5}\right)$ da solução do solo após irrigação com água ou efluente de esgoto nos meses de abril e julho de 2003

26 Produção de massa seca $\left(\mathrm{kg} \mathrm{ha}^{-1}\right)$ da parte aérea do capim-Tifton 85 após irrigação com água ou efluente de esgoto nos meses de abril e julho de $2003 . .$. 


\title{
EFEITO DA IRRIGAÇÃO COM EFLUENTE DE ESGOTO TRATADO, RICO EM SÓDIO, EM PROPRIEDADES QUÍMICAS E FÍSICAS DE UM ARGISSOLO VERMELHO DISTRÓFICO CULTIVADO COM CAPIM-TIFTON 85
}

\author{
Autor: ALEX PAULUS RIBEIRO DOS SANTOS \\ Orientadora: Prof. CÉLIA REGINA MONTES
}

\section{RESUMO}

A escassez natural de água doce no mundo tem sido agravada pela poluição dos cursos de água. Os sistemas de tratamento de esgotos geram resíduos, dentre eles, o efluente de esgoto tratado, que quando lançado em rios, tem causado impacto ambiental. $\mathrm{O}$ uso do efluente de esgoto tem sido considerado uma prática importante para minimizar os impactos negativos aos corpos d'água, sendo que o uso agrícola tem ganhado popularidade em muitos países. Além de se constituir em fonte de água para culturas agrícolas e florestais, o efluente possui elementos essenciais para a nutrição de plantas. No entanto, apesar dos benefícios concretos com o aproveitamento do efluente de esgoto tratado na agricultura, a presença de alguns constituintes como, por exemplo, o Na, pode trazer sérias restrições ao seu uso. O aumento do teor de Na no solo provocado pela irrigação com efluente pode causar toxidez para algumas culturas e modificar propriedades do solo. O presente estudo teve como objetivo verificar os possíveis efeitos da irrigação com efluente em algumas propriedades químicas e físicas de um ARGISSOLO VERMELHO Distrófico cultivado com capim-Tifton 85 no município de Lins/SP. Para atingir o objetivo citado foram realizados estudos que visaram: (i) monitorar a qualidade do efluente, da água de irrigação e da solução do solo quanto à alcalinidade, condutividade elétrica $(\mathrm{CE}), \mathrm{pH}$, razão de adsorção de sódio (RAS) 
e quanto às concentrações de $\mathrm{Na}, \mathrm{Ca}, \mathrm{K}, \mathrm{Mg}$ e $\mathrm{Al}$; (ii) monitorar o $\mathrm{pH}$ do solo, a acidez potencial $(\mathrm{H}+\mathrm{Al})$, os teores dos cátions $\mathrm{Na}, \mathrm{K}, \mathrm{Ca}, \mathrm{Mg}$ e $\mathrm{Al}$ trocáveis no solo; (iii) verificar a possível ocorrência de dispersão de argilas do solo devido à adição de $\mathrm{Na}$ via efluente de esgoto tratado e (iv) determinar a produção de massa seca do capim-Tifton 85 irrigado com água e com efluente. A irrigação com água e efluente foi realizada durante de seis meses por um sistema de irrigação por aspersão convencional, sendo que os volumes adicionados foram determinados com base na manutenção da umidade do solo para desenvolvimento do capim que teve crescimento diferenciado entre os tratamentos. O delineamento experimental foi o de blocos completos casualizados em parcelas subdivididas no tempo, com cinco tratamentos e quatro repetições. Tanto o efluente quanto a água apresentaram altos valores de RAS, porém, os menores valores foram observados para o efluente. A acidificação do solo e da solução ocorreu após irrigação com água e efluente. $\mathrm{O} \mathrm{Al}$ trocável aumentou devido a redução do $\mathrm{pH}$. Tanto a água quanto o efluente ocasionaram aumento do teor de Na no solo, devido à elevada concentração desse elemento na água e no efluente. A dispersão de argilas ocorreu em toda a área e o aumento com o tempo foi mais pronunciado em superfície o que está de acordo com o maior aumento do percentual de sódio trocável (PST) e da RAS da solução do solo. O efluente foi eficiente em suprir o capim-Tifton com água, não resultando em prejuízo de acúmulo de massa seca em relação ao tratamento de irrigação com água. 


\title{
EFFECTS OF SPRINKLER IRRIGATION WITH TREATED SEWAGE EFFLUENT, RICH IN SODIUM, ON THE CHEMICAL AND PHYSICAL PROPERTIES OF A TYPIC HAPLUDULTS CULTIVATED WITH TIFTON 85 GRASS
}

\author{
Author: ALEX PAULUS RIBEIRO DOS SANTOS \\ Adviser: Prof. CÉLIA REGINA MONTES
}

\section{SUMMARY}

The natural scarcity of freshwater in the world has been aggravated by the pollution of the watercourses. The systems of treatment of sewage generate residues, such as treated sewage effluent, that when launched into rivers, has caused environmental impact. The use of the sewage effluent has been considered an important practice to minimize the negative impacts on the water supplies, and its use in agriculture has gained popularity in many countries. Besides being a water source for agricultural and forest cultures, the effluent contains essential elements for plant nutrition. However, despite the benefits of the use of treated sewage effluent in agriculture, the presence of some constituent such as $\mathrm{Na}$ brings restriction to its use. The level of $\mathrm{Na}$ in the soil may increase by means of the irrigation with effluent, and it may cause toxicity to some cultures and modify soil properties. The present study had the objective to verify the possible effects of the irrigation with effluent on some chemical and physical properties of a Typic Hapludults cultivated with Tifton 85 grass in the city of Lins/SP. The studies carried out aimed at: (i) monitoring the quality of the effluent, the irrigation water and the soil solution in relation to the alkalinity, electrical conductivity (EC), $\mathrm{pH}$, sodium adsorption ratio (SAR) and in relation to the concentrations of $\mathrm{Na}, \mathrm{Ca}, \mathrm{K}, \mathrm{Mg}$ and $\mathrm{Al}$; (ii) 
monitoring the $\mathrm{pH}$ of the soil, the potential acidity $(\mathrm{H}+\mathrm{Al})$, the levels of $\mathrm{Na}, \mathrm{Ca}, \mathrm{K}, \mathrm{Mg}$ cations and exchangeable $\mathrm{Al}$ in the soil; (iii) verifying the possible occurrence of clay dispersion in the soil due to addition of $\mathrm{Na}$ through treated sewage effluent and (iv) determining the production of dry mass of Tifton 85 grass. The irrigation with water and effluent was carried out for six months by the use of a sprinkler irrigation system, being that the added volumes had been determined on the basis of the maintenance of the humidity of the soil for the development of grass that had growth differentiated between the treatments. The experimental design was a split plot scheme of randomized blocks subdivided in time, with five treatments (A, E1, E2, E3 and E4) and four replications. Both effluent and water presented high values of SAR, however, lower values were observed for the effluent. The acidification of the soil and the solution occurred after the irrigation with water and effluent. The exchangeable Al increased due to the reduction of $\mathrm{pH}$. Both water and effluent increased the level of $\mathrm{Na}$ in the soil, due to the high concentration of this element in the water and in the effluent. The dispersion of clay occurred in all the area, and the increase in time was higher in the surface in accordance with the highest increase of exangeable sodium percentage (ESP) and SAR of the soil solution. The effluent was efficient in supplying Tifton grass with water, not resulting in dry mass accumulation losses in relation to the treatment of irrigation with water. 


\section{INTRODUÇÃO}

A distribuição irregular de água doce no mundo e sua conseqüente escassez natural em certas regiões, agravada pela poluição, crescimento demográfico e uso desordenado dos recursos naturais, faz dela um bem cada dia mais importante para a sobrevivência do homem na Terra. Observa-se que a intervenção humana tem alterado, de forma dramática, o ciclo natural de renovação dos recursos hídricos, o que tem reduzido a pequena parcela de água potável que cobre o planeta.

Os sistemas de tratamento de esgotos geram resíduos como o lodo de esgoto e o efluente de esgoto tratado. O efluente é, geralmente, lançado em cursos d'água causando poluição ambiental. $\mathrm{O}$ uso do efluente em diferentes atividades humanas tem sido uma alternativa sustentável frente ao quadro de escassez, pois contribui para a preservação da água doce disponibilizando-a para consumos que exigem potabilidade, como o uso doméstico. Sendo a agricultura a atividade que mais consome água doce, o aproveitamento agrícola de efluentes de esgoto tratado, gerados em lagoas de estabilização, é prática comum em muitos países. No Brasil, somente recentemente o uso de efluente de lagoas de estabilização na agricultura vem sendo considerado.

O aproveitamento do efluente na agricultura, além de constituir numa prática de reuso da água e preservação da qualidade dos recursos hídricos, traz outros benefícios como a contribuição para a nutrição de culturas agrícolas e florestais, pelo fato dos efluentes possuírem alguns elementos essenciais às plantas. Em determinadas épocas do ano o efluente pode ser uma importante fonte de água para as culturas. Entretanto, apesar dos benefícios concretos com o aproveitamento do efluente na agricultura, a presença de alguns constituintes, como o sódio ( $\mathrm{Na}$ ) e metais pesados, é indesejável. Os metais pesados são motivos de preocupação principalmente na utilização 
de efluentes industriais ou com o uso de efluentes domésticos por longo período de tempo. O teor de sódio em solos agrícolas pode aumentar com a adição de efluente alterando certas características físicas do solo, devido à dispersão de argilas e características químicas, influenciando direta ou indiretamente o desenvolvimento das plantas. A dispersão de argilas é uma das causas da redução da porosidade do solo, condutividade hidráulica, taxa de infiltração e da destruição da estrutura do solo (Feigin et al., 1991).

O aporte e a dinâmica do sódio em solos cultivados depende de fatores como: (i) concentração de sódio no efluente ou na água utilizados para irrigação; (ii) absorção pelas plantas; (iii) intensidade de lixiviação no perfil do solo; (iv) permeabilidade do solo e (v) dinâmica de outros íons, como cálcio, magnésio, carbonatos e bicarbonatos, na solução e no complexo de troca do solo. Assim, o estudo desses fatores tem grande importância e deve constituir parte do manejo adotado em sistemas de irrigação com efluentes de esgotos e outras águas residuárias em agrossistemas.

No município de Lins/SP, um projeto de ampla magnitude vem sendo desenvolvido no sentido de avaliar a possibilidade de uso do efluente de esgoto tratado na agricultura. Sendo o teor de $\mathrm{Na}$ um dos mais limitantes para a sua utilização como fonte de água para a irrigação, o presente trabalho tem por objetivos verificar os possíveis efeitos da sua aplicação em algumas propriedades químicas e físicas de um ARGISSOLO VERMELHO Distrófico cultivado com capim-Tifton 85.

Portanto, foram realizados estudos que visaram: (i) monitorar a qualidade do efluente, água de irrigação e solução do solo quanto à alcalinidade, condutividade elétrica $(\mathrm{CE}), \mathrm{pH}$, razão de adsorção de sódio (RAS) e quanto às concentrações dos cátions $\mathrm{Na}, \mathrm{Ca}, \mathrm{K}, \mathrm{Mg}$ e $\mathrm{Al}$; (ii) monitorar o $\mathrm{pH}$ do solo, a acidez potencial $(\mathrm{H}+\mathrm{Al})$, os teores dos cátions $\mathrm{Na}, \mathrm{K}, \mathrm{Ca}, \mathrm{Mg}$ e $\mathrm{Al}$ trocáveis no solo; (iii) verificar a possível ocorrência de dispersão de argilas do solo devido à adição de $\mathrm{Na}$ via efluente de esgoto tratado e (iv) determinar a produção de massa seca do capim-Tifton 85. 


\section{REVISÃO DA LITERATURA}

\subsection{Necessidade do uso de efluentes de esgoto e de outras águas residuárias}

$\mathrm{Na}$ medida em que as populações e as atividades econômicas crescem, muitos países estão atingindo rapidamente condições de escassez de água ou se defrontando com limites para o desenvolvimento econômico. O manejo holístico da água doce como um recurso finito e vulnerável e a integração de planos e programas hídricos setoriais aos planos econômicos e sociais nacionais são medidas de importância fundamental (Agenda 21).

As demandas por água estão aumentando rapidamente, com 70 a $80 \%$ exigidos para a irrigação, menos de $20 \%$ para a indústria e apenas $6 \%$ para consumo doméstico (Agenda 21). Assim, o caminho para assegurar a água requerida pela irrigação é a reutilização das águas residuárias das cidades após sua coleta e tratamento. Para tanto é necessário priorizar a garantia dos padrões de higiene e a não existência de efeitos adversos ao ambiente (Salem, 1996). Normalmente, os padrões de qualidade para águas de irrigação são menos restritivos quando comparados aos de outros usos que exigem maior potabilidade. Desse modo, para águas de irrigação, tratamentos menos dispendiosos e mais simples são necessários (Vazquez-Montiel et al., 1996).

Nas regiões áridas e semi-áridas, a água tornou-se um fator limitante para o desenvolvimento urbano, industrial e agrícola. Entretanto, o fenômeno da escassez não é atributo exclusivo dessas regiões. Muitas regiões com recursos hídricos abundantes, mas insuficientes para atender a demandas excessivamente elevadas, também experimentam conflitos de usos e sofrem restrições de consumo, que afetam o desenvolvimento econômico e a qualidade de vida. A Bacia do Alto Tietê, por exemplo, que abriga uma população superior a 15 milhões de habitantes e um dos maiores 
complexos industriais do mundo, dispõe de vazões insuficientes para a demanda da Região Metropolitana de São Paulo e municípios circunvizinhos. Isto tem levado à busca incessante de recursos hídricos complementares de bacias vizinhas, que trazem, como conseqüência direta, aumentos consideráveis de custo, além dos evidentes problemas legais e político-institucionais associados (Hespanhol, 2002).

A prática corrente de descarte de efluentes envolve a sua descarga em águas superficiais após alguns tratamentos preliminares. Entretanto, a legislação mais rigorosa sobre a qualidade da água para proteção da saúde humana e do ambiente, juntamente à necessidade da garantia do suprimento de água, tem levado a uma reavaliação desta prática (Vazquez-Montiel et al., 1996).

Existem poucas opções sustentáveis para o tratamento e disposição de águas residuárias. Há vários benefícios com a disposição de águas residuárias em rios que incluem a manutenção de um fluxo ambiental adequado com aumento do volume de água para consumo a jusante dos rios. Entretanto, a disposição em rios pode acelerar os processos de eutroficação em águas naturais, deste modo, a alternativa de disposição de efluentes no solo tem ganhado popularidade (Bond, 1998; Halliwell et al., 2001).

Os padrões de lançamento de efluentes e padrões de qualidade de corpos receptores estabelecidos pelo Conselho Nacional do Meio Ambiente (Conama) têm como objetivo a preservação dos corpos d'água. No entanto, apesar de esforços com base na legislação vigente, a redução da qualidade da água e a poluição de fontes de superfície e subterrâneas têm sido observadas. Os problemas mais graves que afetam a qualidade da água de rios e lagos decorrem de vários fatores, dentre eles, o tratamento inadequado de esgotos domésticos (Agenda 21).

Portanto, alternativas têm sido propostas como o uso de efluentes de esgotos na agricultura. A aplicação de efluentes na agricultura, sendo estes gerados em sistemas de tratamento por meio de lagoas de estabilização, já é prática comum em muitos países, fazendo parte de programas governamentais de irrigação e gestão de recursos hídricos, como é o caso de Israel, Egito, Austrália, Arábia Saudita, Tunísia e Chile (Pescod, 1992). No Brasil, os governos estaduais e federais devem iniciar, 
imediatamente, processos de gestão para estabelecer bases políticas, legais e institucionais para o reuso. Uma política criteriosa de reuso transforma a problemática poluidora e agressiva dos esgotos em um recurso econômico e ambientalmente seguro (Hespanhol, 2002).

Especial atenção deve ser atribuída ao reuso da água para fins agrícolas tendo em vista as grandes vazões envolvidas nesta atividade (chegando a até $80 \%$ do uso consuntivo em alguns países). A agricultura depende, atualmente, de suprimento de água a um nível tal que a sustentabilidade da produção de alimentos não poderá ser mantida, sem o desenvolvimento de novas fontes de suprimento e a gestão adequada dos recursos hídricos convencionais (Hespanhol, 2002).

\subsection{Disposição de efluente de esgoto tratado no agrossistema}

O solo e plantas atuam como "filtro vivo" absorvendo e retendo poluentes e organismos patogênicos presentes em resíduos e águas residuárias. Esta disposição completa a seqüência de tratamentos de águas residuárias para redução dos níveis de microorganismos e de vários componentes orgânicos e inorgânicos para níveis aceitáveis (Feigin et al., 1991).

O uso de água residuária tratada para a irrigação na agricultura, segundo Oron, (1996), é uma prática atrativa, pois: (i) problemas com a falta de água podem ser resolvidos; (ii) grandes quantidades podem ser dispostas durante todo o ano com ou sem armazenamento no solo (em algumas circunstancias o armazenamento pode ser considerado uma fase extra de tratamento) e com riscos ambientais mínimos; (iii) há benefícios econômicos devido à presença de nutrientes no efluente. Na Tabela 1 são apresentadas as características dos efluentes domésticos secundários quanto a sua constituição.

A presença de nutrientes às plantas em efluentes de esgoto tratado é um aspecto favorável em se tratando da irrigação de culturas agrícolas e florestais, e indesejável para o lançamento desses resíduos em corpos d'água. Piveli \& Doria (2003) em estudo das condições operacionais do sistema de tratamento de esgotos por lagoas de estabilização em Lins-SP, verificaram baixa remoção de nitrogênio (Nitrogênio total 
Kjeldhal e Amoniacal) e de fósforo (total) por este sistema biológico de tratamento. Os autores sugeriram que esforços devam ser envidados no sentido de melhorar as características destes efluentes para o lançamento nos corpos de água naturais (atenção voltada para constituintes químicos e biológicos) ou para a disposição no solo (maior preocupação com constituintes biológicos).

Tabela 1. Características dos efluentes domésticos secundários

\begin{tabular}{cc}
\hline Constituintes & Concentração \\
Sólidos totais & $400-1200$ \\
Sólidos totais suspensos & $10-100$ \\
Sólidos totais dissolvidos & $400-100$ \\
DBO & $10-80$ \\
COD & $30-160$ \\
Nitrogênio total & $10-50$ \\
Nitrogênio - nitrato & $0-10$ \\
Nitrogênio - amônio & $1-40$ \\
Fósforo total & $6-17$ \\
Cloretos & $40-200$ \\
Alcalinidade (carbonato de cálcio) & $200-700$ \\
Sódio & $50-250$ \\
Potássio & $10-40$ \\
Cálcio & $20-120$ \\
Magnésio & $10-50$ \\
Boro & $0-1$ \\
pH & $7,8-8,1$ \\
RAS & $4,5-7,9$ \\
\hline
\end{tabular}

Fonte: Pound \& Crites (1973), Thomas \& Law (1977), Idelovitch (1979), Asano et al. (1985) citados por Feigin et al. (1991).

(1) Todas as unidades em mg L ${ }^{-1}$, exceto para os valores de RAS $\left(\mathrm{mmol} \mathrm{L}^{-1}\right)^{1 / 2}$ e $\mathrm{pH}$.

Estudos efetuados em diversos países demonstraram que a produtividade agrícola aumenta significativamente em sistemas de irrigação com esgotos adequadamente administrados (Hespanhol, 2002). Como exemplo, são apresentados na Tabela 2 alguns resultados experimentais obtidos em Nagpur, Índia, em estudo de irrigação das culturas do trigo, feijão, arroz, batata e algodão. 
Tabela 2. Aumento de produtividade agrícola (ton $\mathrm{ha}^{-1} \mathrm{ano}^{-1}$ ) mediante a irrigação com esgotos domésticos

\begin{tabular}{lccccc}
\hline Irrigação efetuada com & $\begin{array}{c}\text { Trigo } \\
8 \text { anos }\end{array}{ }^{(1)}$ & $\begin{array}{c}\text { Feijão } \\
5 \text { anos }\end{array}{ }^{(1)}$ & $\begin{array}{c}\text { Arroz } \\
7 \operatorname{anos}^{(1)}\end{array}$ & $\begin{array}{c}\text { Batata } \\
4 \operatorname{anos}^{(1)}\end{array}$ & $\begin{array}{c}\text { Algodão } \\
3 \text { anos }\end{array}{ }^{(1)}$ \\
\hline Esgoto bruto & 3,34 & 0,9 & 2,97 & 23,11 & 2,56 \\
Efluente primário & 3,45 & 0,87 & 2,94 & 20,78 & 2,3 \\
Efluente de lagoa de & 3,45 & 0,78 & 2,98 & 22,31 & 2,41 \\
estabilização & 2,7 & 0,72 & 2,03 & 17,16 & 1,7 \\
Água + NPK &
\end{tabular}

(1) Número de anos para cálculo da produtividade média;

Fonte: Resultados experimentais obtidos em Nagpur, Ïndia, pelo Instituto Nacional de Pesquisa de Engenharia Ambiental (NEERI), citados por Hespanhol (2002).

Kouraa et al. (2002) obtiveram resultados positivos com a irrigação de culturas de alface e batata com efluente de esgoto tratado por meio de lagoas de estabilização. O efluente de esgoto supriu quase que totalmente as quantidades de nitrogênio, fósforo e potássio requeridas pelas culturas.

Comparado a outros tipos de reuso, o uso agrícola de efluentes apresenta benefícios como a reciclagem de nutrientes através da irrigação de culturas e o fornecimento de água (Vazquez-Montiel et al., 1996). Johns \& McConchie (1994) constataram a eficiência do efluente como fonte de água e de nutrientes no cultivo de bananeiras. Segundo os autores, a adição de $600 \mathrm{~mm}$ de efluente tratado pode fornecer $21 \%$ de N, $100 \%$ de $\mathrm{P}, 21 \%$ de K, $20 \%$ de Ca e $50 \%$ de $\mathrm{Mg}$ do total de $\mathrm{kg}$ de nutrientes necessários anualmente para a produção de bananeiras.

$\mathrm{O}$ uso de águas residuárias na agricultura pode afetar a produtividade de culturas reduzindo a necessidade do uso de fertilizaçãomineral. Permite um considerável suprimento de nitrogênio, tanto na forma orgânica como mineral (Meli, et al., 2002). Onde o efluente de esgoto é aplicado em pequenas quantidades, o solo é predominantemente aeróbico e o nitrogênio do efluente será convertido em nitrato $\left(\mathrm{NO}_{3}{ }^{-}\right)$(Bouwer \& Chaney, 1974). 
Maiores aumentos das concentrações de $\mathrm{NO}_{3}{ }^{-}, \mathrm{Ca}^{+2}$ e $\mathrm{P}$ disponível foram observados por Johns \& McConchie (1994) em camadas superficiais de solos irrigados com efluente de esgoto do que em solos irrigados com água. Porém, aumentos da concentração de $\mathrm{Na}^{+}$foram observados tanto em camadas superficiais quanto em camadas profundas em tratamentos de irrigação com efluente ou água. Yadav et al. (2002) observaram maior acúmulo de sais em superfície do que em camadas subsuperficiais do solo após irrigação com efluente de esgoto doméstico. Acúmulos de $\mathrm{Na}$ predominaram em superfície, porém também foram observados em subsuperfície.

A umidade do solo bem como os valores de $\mathrm{pH}$ tem sido aumentados em solos irrigados com efluentes de esgoto tratado que apresentam maior relação carbono/nitrogênio (Magesan et al., 2000). Falkiner \& Smith (1997) observaram aumento do $\mathrm{pH}$ do solo em cerca de 0,7 unidades para tratamento com efluente e 0,3 unidades para tratamento com água em sistema de cultivo florestal após 4 anos de irrigação. Aumento do pH em solos de campo (4 anos de irrigação) e floresta (17 anos de irrigação), sob irrigação com efluente, também foi observado por Smith et al. (1996). Porém, Johns \& McConchie (1994) constataram, na camada de 0 a $20 \mathrm{~cm}$ de um solo irrigado para cultivo de bananeiras, decréscimo de $\mathrm{pH}$ de 0,55 unidades nos tratamentos com água e de apenas 0,31 unidades nos tratamentos com efluente.

Johns \& McConchie et al. (1994) observaram que as plantas de bananeiras irrigadas com efluente contêm teores mais elevados de certos elementos em comparação a plantas irrigadas com água: $225 \%$ a mais de sódio, $81 \%$ a mais de boro, $43 \%$ a mais de cobre, $26 \%$ a mais de cloro e cerca de $16 \%$ a mais de nitrogênio, fósforo, potássio e magnésio.

Após 15 anos de irrigação com efluente de esgoto, Meli et al. (2002) constataram no solo aumento na quantidade de nutrientes disponíveis juntamente à eficiência metabólica da microflora do solo. Por outro lado Ortega-Larrocea et al. (2001) constataram efeito negativo sobre a população de fungos micorrízicos arbusculares no solo (decréscimo da abundância de esporos livres) após 90 anos de irrigação com efluente de esgoto, associando este fato ao acúmulo de fósforo e de metais pesados. 
Correlação positiva entre a maior relação $\mathrm{C} / \mathrm{N}$ do efluente e o aumento do $\mathrm{C}$ e $\mathrm{N}$ da biomassa microbiana do solo foi constatada em estudo de irrigação com efluente de esgoto tratado. Correlação negativa foi verificada entre a relação $\mathrm{C} / \mathrm{N}$ do efluente e os teores de N-mineral e N-solúvel total e condutividade hidráulica do solo (Magesan et al., 2000).

Ao contrário do que se tem observado em solos após vários anos sob irrigação com efluente de esgoto tratado, a irrigação num curto período de tempo (meses), não têm alterado características físicas e químicas do solo. Do mesmo modo que para as alterações químicas e físicas, a contaminação bacteriológica do solo não tem sido significante após curto período de irrigação (Kouraa et al., 2002).

Além da prática de irrigação de culturas agrícolas, o efluente de esgoto tem sido empregado com sucesso como solução nutritiva em cultivos hidropônicos, sendo este sistema uma alternativa para a reciclagem de águas residuárias Mavrogianopoulos et al. (2002).

\subsubsection{Desafios para o uso agrícola de efluente de esgoto tratado}

No contexto da irrigação de culturas agrícolas com efluentes de esgoto, é importante considerar que estas águas residuárias apresentam mais impurezas que águas de fontes naturais, podendo ser potencialmente prejudiciais dependendo das características que apresentam e das práticas de manejo adotadas para o seu uso (Vazquez-Montiel et al., 1996). Sérios problemas ambientais como a lixiviação de nitrato, aumento de elementos tóxicos em solos e plantas, e riscos à saúde humana devido a microorganismos patogênicos, podem ocorrer (Vazquez-Montiel et al., 1996; Hespanhol, 2002).

Entretanto, diretrizes podem ser adotadas isoladamente ou de forma combinada no uso de águas residuárias na agricultura: tratamento da água residuária, restrições a culturas, controle da aplicação da água residuária, controle da exposição humana e promoção da higiene (Pescod, 1992). 


\subsubsection{Constituintes tóxicos, organismos patogênicos e contaminantes do ambiente}

A sustentabilidade da irrigação de culturas agrícolas com efluente de esgoto depende, dentre outras coisas, da qualidade microbiológica do efluente (Bouwer \& Chaney, 1974). Organismos patogênicos (vírus, bactérias, protozoários e ovos de helmintos) podem estar associados à transmissão de doenças para pessoas e animais expostos ao efluente por contato físico acidental, pela inalação de aerossóis formados pela pulverização do efluente durante algumas práticas de irrigação ou pelo consumo de culturas irrigadas com efluente (Feigin et al., 1991).

Piveli \&Doria (2003) obtiveram em algumas campanhas de amostragem e análises de efluente de esgoto tratado pelo sistema de tratamento de esgoto de Lins/SP, resultados positivos de bactérias patogênicas do gênero Aeromonas sp e Salmonella sp. Segundo os autores estes resultados levam à busca de alternativas para o pós-tratamento (como por exemplo, cloração, radiação ultravioleta e ozonização) e disposição final desses efluentes. Os resultados para ovos de helmintos foram considerados surpreendentes com redução em torno de $63 \%$, resultado bem abaixo dos apresentados por outros sistemas (90 a $100 \%$ ) de tratamento de esgoto com características semelhantes.

Se a prática da irrigação com efluente não for cuidadosamente manejada, esta poderá resultar na recarga de águas subsuperficiais acompanhada por sais e nitratos, acumulação de outros elementos químicos (como sódio e fósforo) no solo e associado aumento do risco de escoamento superficial desses elementos para os cursos de água.

Dependendo da fonte do efluente, contaminantes como os metais pesados e outros componentes tóxicos podem também se acumular no solo ou serem lixiviados para águas subterrâneas (Bond, 1998). O acúmulo de sódio, cloro ou boro em cultivos sensíveis a altas concentrações desses elementos causa danos às plantas e redução da produtividade (Ayers \& Westcot ,1985).

O nível de cloretos no efluente secundário é normalmente maior do que o encontrado na água para abastecimento. $\mathrm{O}$ tratamento de esgotos padrão não remove o 
cloro do efluente devido à elevada solubilidade dos compostos de cloro. As tecnologias de dessalinização para remover cloro são muito caras. Em geral, os níveis de cloro nos efluentes municipais secundários permanecem abaixo daqueles considerados prejudiciais para a maioria das culturas agrícolas, no entanto, altas concentrações desse elemento no efluente de esgoto, como em outras fontes de água, podem atingir águas subterrâneas (Feigin et al., 1991).

\subsubsection{Salinização e sodificação de solos}

Todos os solos contêm uma mistura de sais solúveis, dentre os quais, muitos são essenciais ao desenvolvimento de plantas enquanto outros não são prejudiciais quando em baixas concentrações. No entanto, quando as concentrações de sais são excessivas o desenvolvimento das plantas é prejudicado (Mass, 1985; Ayers \& Westcot ,1985).

Ao contrário dos solos ácidos, nos quais o mecanismo de lixiviação promove a retirada de cátions básicos do perfil do solo, os solos salinos se desenvolvem em conseqüência do acúmulo de sais e, em particular, de sódio (Raij, 1991). O processo de salinização é comum em regiões de clima árido e semiárido onde as chuvas não são suficientes para remover os sais do solo (Marschner, 1995). A ausência de lixiviação pronunciada possibilita o acúmulo de sais no solo, o que se agrava com a irrigação, uma vez que a água utilizada sempre carreia sais para o solo (Raij, 1991).

Os sais solúveis do solo são constituídos principalmente dos cátions $\mathrm{Ca}^{+2}$ e $\mathrm{Mg}^{+2}$ e dos ânions $\mathrm{Cl}^{-}$e $\mathrm{SO}_{4}{ }^{-}$. O cátion $\mathrm{K}$ e os ânions $\mathrm{HCO}_{3}{ }^{-}, \mathrm{CO}_{3}{ }^{-}$e $\mathrm{NO}_{3}{ }^{-}$se encontram geralmente em quantidades menores (Richards, 1954). Os solos afetados por sais podem ser classificados como salinos (apresentam altas concentrações de sais solúveis), sódicos (com altas concentrações de sódio trocável) e salino-sódicos (apresentam altas concentrações de sais e de sódio trocável) (Meurer, 2000). A salinidade e sodicidade do solo são normalmente expressas pela condutividade elétrica (CE), percentual de sódio trocável (PST) e pH, segundo classificação de solos sódicos e salinos elaborada pelo Laboratório de Salinidade dos Estados Unidos e descrita em Richards (1954): 
- Solo não sódico e não salino - $\mathrm{CE}<4 \mathrm{dS} . \mathrm{m}^{-1} / \mathrm{PST}<15 \%$ / pH $<8,5$

- Solo salino - CE $>4 \mathrm{dS} \cdot \mathrm{m}^{-1} / \mathrm{PST}<15 \% / \mathrm{pH}<8,5$

- Solo sódico - CE $<4 \mathrm{dS} . \mathrm{m}^{-1} / \mathrm{PST}>15 \% / \mathrm{pH}>8,5$

- Solo salino-sódico - CE $>4 \mathrm{dS} . \mathrm{m}^{-1} / \mathrm{PST}>15 \% / \mathrm{pH}<8,5$

Os sais são adicionados a água através do uso doméstico e industrial. As quantidades adicionadas diferem entre as localidades, podendo variar entre $100 \mathrm{e}$ $800 \mathrm{mgL}^{-1}$. Em geral, dentro de uma mesma localidade as variações são pequenas. Em alguns casos, mesmo em concentrações relativamente baixas, os sais adicionados são suficientes para alterar a qualidade da água de aceitável para questionável, do ponto de vista agrícola (Feigin et al., 1991).

Sais dissolvidos em águas residuárias interagem com o solo por meio de troca iônica, dispersão e floculação de argilas (Bouwer \& Chaney, 1974). Quando presentes no solo ou na água podem reduzir a disponibilidade de água para as culturas afetando o rendimento (Ayers \& Westcot, 1985). Maiores concentrações de sais na solução de percolação no solo podem ocorrer se a quantidade de água residuária adicionada (mais a precipitação) não for muito maior que a evapotranspiração (Bouwer \& Chaney, 1974).

Três são os principais aspectos relacionados à composição dos efluentes que, segundo Feigin et al. (1991), constituem em riscos de salinização e sodificação de solos quando utilizados como água na agricultura: (i) a concentração total de sais na água pode causar aumento da salinidade do solo; (ii) as concentrações de certos íons como $\mathrm{Cl}^{-}$e $\mathrm{Na}^{+}$podem causar, direta ou indiretamente, efeitos tóxicos às plantas, incluindo desequilíbrio nutricional; (iii) as concentrações de certos íons (principalmente $\mathrm{Na}^{+}$e $\mathrm{HCO}_{3}{ }^{-}$) podem resultar na deterioração da estrutura do solo e conseqüentemente na redução da permeabilidade.

\section{- Efeito do íon sódio}

No que se refere à nutrição de plantas, o sódio pode ser desejável para certas culturas como, por exemplo, para a beterraba açucareira. Em alguns casos, o sódio pode substituir parcialmente o potássio, sobretudo em plantas $\mathrm{C}_{4}$ (Marschner, 1995). Em 
certas regiões, a aplicação de sódio em adubação de forrageiras tem sido considerada útil, para aumentar o teor do elemento e por melhorar a aceitabilidade da forragem pelo animal, resultando em maior consumo (Raij, 1991).

Considerando a presença do $\mathrm{Na}^{+}$no solo, este apresenta comportamento similar ao do potássio e, nas soluções naturais, ocorre como cátion $\mathrm{Na}^{+}$trocável. Esse íon é facilmente removido do solo por lixiviação e, em geral, há menos sódio total que potássio em solos de climas úmidos (Raij, 1991). No entanto, solos sódicos ácidos, notadamente caracterizados pelo acúmulo de $\mathrm{Na}^{+}$, são encontrados em regiões de alta precipitação (precipitação anual de 550-750 mm) onde cátions básicos como $\mathrm{Ca}^{+2}$ e $\mathrm{Mg}^{+2}$ são lixiviados e suas concentrações são baixas. Estes solos são altamente intemperizados com CTC geralmente baixa (Rengasamy \& Olsson, 1991).

Havendo o acúmulo de $\mathrm{Na}^{+}$, efeitos negativos para a estrutura do solo podem ocorrer, caracterizando o processo de sodificação. Formas de entender o mecanismo de sodificação do solo são encontradas na literatura como, por exemplo, a “equação de balanço de sódio" proposta por Rengasamy \& Olsson (1993). A equação é obtida pela soma de várias "entradas"e "saídas" de espécies iônicas para solução do solo:

$$
S C M_{s s}=\left(S C M_{a i+a c}+S C M_{s+m}+S C M_{c+f}+S C M_{l f}\right)-\left(S C M_{a d}+S C M_{p+c}+S C M_{a b s}\right)
$$
em que,

- SCM = concentrações de $\mathrm{Na}^{+}, \mathrm{Ca}^{+2}$ e $\mathrm{Mg}^{+2}$;

- índices: ss (solução do solo), ai (água de irrigação), ac (água da chuva), s (sólidos), $m$ (minerais), $c$ (corretivos), $f$ (fertilizantes), If (lençol freático), ad (água de drenagem), $p$ (precipitação), $c$ (complexação) e abs (absorção pelas plantas).

Devido ao grande impacto nas propriedades do solo e rendimento das culturas, a determinação dos níveis de $\mathrm{Na}^{+}$na água de irrigação é essencial (Feigin et al., 1991). A irrigação com efluente comumente resulta em incremento da sodicidade devido à média-alta salinidade e altas concentrações de sódio de muitos efluentes (Balks et al., 1998). As concentrações de $\mathrm{Na}^{+}$no efluente de esgoto variam de 
50 a $250 \mathrm{mg} \mathrm{L}^{-1}$. Supondo a aplicação de uma lâmina de $100 \mathrm{~mm}$ de efluente no solo, na concentração de $250 \mathrm{mg} \mathrm{L}^{-1}$ de $\mathrm{Na}^{+}$, há um aporte de $250 \mathrm{~kg} \mathrm{ha}^{-1} \mathrm{de} \mathrm{Na}^{+}$.

Os cátions $\mathrm{Ca}^{+2}$ e $\mathrm{Mg}^{+2}$ são os que predominam da solução do solo e no complexo de troca de cátions do solo. Quando nestes solos passa a haver um acúmulo de sais solúveis, geralmente é o $\mathrm{Na}^{+}$que predomina na solução do solo e, desta forma, o $\mathrm{Na}^{+}$pode passar a ser o cátion predominante no complexo de troca devido ao deslocamento de $\mathrm{Ca}^{+2}$ e $\mathrm{Mg}^{+2}$ e conseqüente precipitação de desses cátions na solução do solo (Richards, 1954).

A grande proporção de $\mathrm{Na}^{+}$nos sítios de troca dos minerais de argila reduz a atração entre as partículas do solo ocasionando expansão e dispersão. As partículas dispersas movem-se pelo solo ocupando os espaços porosos (Irvine \& Reid, 2001) com conseqüente deterioração da estrutura do solo e das propriedades de infiltração de água e aeração, sendo problema sério em solos alcalinos, afetando o crescimento vegetal (Raij, 1991; Rengasamy \& Olsson, 1991).

Em solos sódicos os processos primários responsáveis pela degradação física são a expansão das argilas em níveis relativamente altos e a dispersão devido à alteração do PST do solo (Sumner, 1993; Halliwell et al., 2001). Quando a concentração total de eletrólitos (CTE) na solução do solo permanece abaixo da concentração crítica de floculação $(\mathrm{CCF})$ (mínima concentração eletrolítica em que ocorre floculação das argilas) as argilas dispersam espontaneamente em altos valores de PST, entretanto, em baixos valores de PST, energia adicional é necessária para ocorrer a dispersão (Sumner, 1993).

O grau de expansão e dispersão de argilas do solo depende da natureza do argilomineral predominante. Maior sensibilidade para esses processos é tida para a montmorilonita, sensibilidade moderada para a ilita e menor sensibilidade para a caolinita (Feigin et al., 1991) Em solos que contém minerais de carga variável a floculação pode ser promovida pela interação de superfícies de cargas opostas (Shofield \& Samson, 1954) indicando que nesses solos podem ser esperados valores mais baixos de CCF do que em solos montmoriloníticos. Shofield \& Samson (1954) 
demonstraram que a caolinita saturada com $\mathrm{Na}^{+}$sofreu o processo de floculação, porém, este mineral quando misturado a pequenas quantidades de montmorilonita ou ilita foi dispersado devido a esses minerais terem sido pequenos suficientemente para neutralizarem as cargas positivas das arestas das caolinitas.

Rengasamy \& Olsson (1991) propuseram a classificação de solos sódicos como solos sódicos ácidos (acidic sodic), sódicos neutros (neutral sodic) e sódicos alcalinos (alkaline sodic). Conforme as condições de acidez, neutralidade e alcalinidade, a composição da solução do solo dos solos sódicos varia conforme é mostrado no esquema de classificação a seguir (Figura 1):

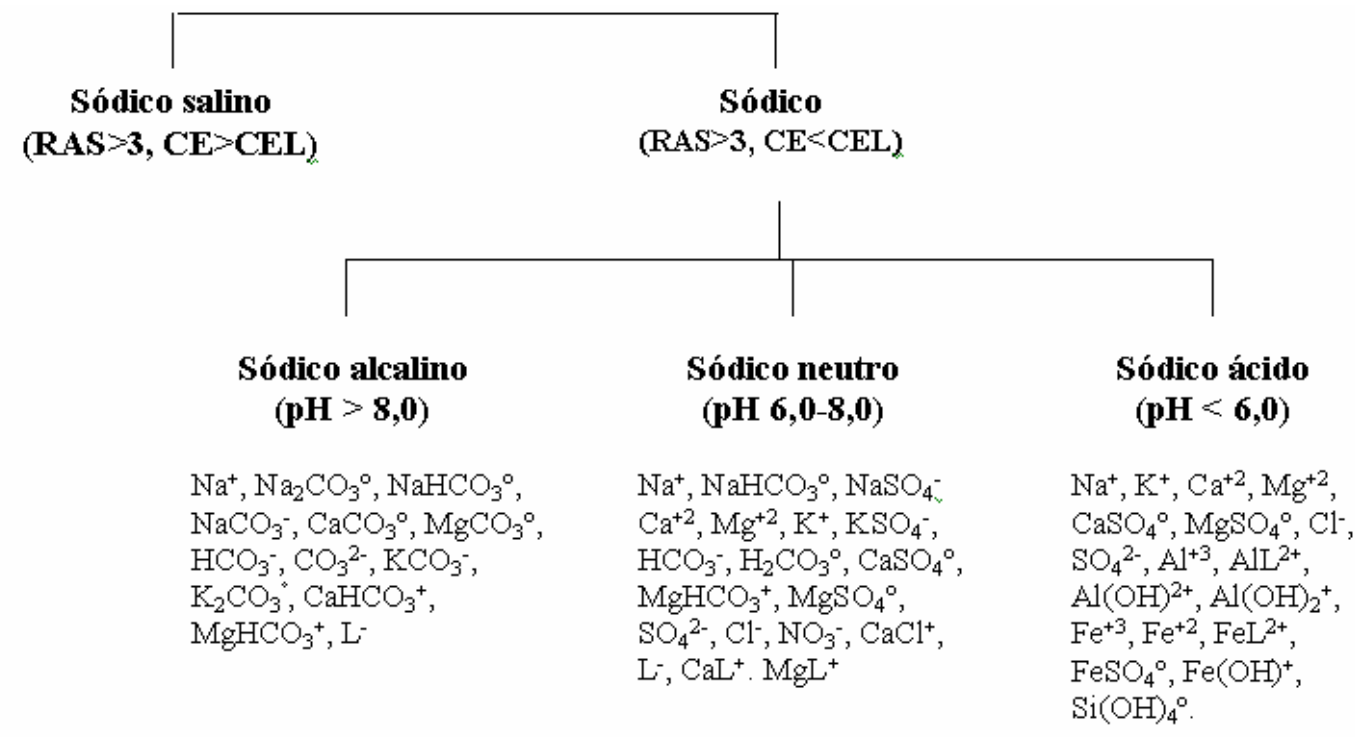

- RAS= razão de adsorção de sódio;

- $\mathrm{CE}=$ concentração eletrolítica;

- L = Ligantes orgânicos;

- $\mathrm{CEL}$ = concentração eletrolítica limite (mínima concentração eletrolítica para que haja floculação de argilas).

Figura 1 - Classificação de solos sódicos e espécies químicas predominantes (adaptado de Rengasamy \& Olsson (1991)

Com base no esquema de classificação anterior, os autores consideram a RAS (termodinamicamente relacionada ao PST), o pH e a concentração eletrolítica (determinada pela condutividade elétrica), determinados em extrato aquoso 1:5, como 
sendo os fatores mais importantes no diagnóstico de efeitos deletérios da sodicidade na estrutura do solo.

Dentre as espécies químicas encontradas na solução do solo de solos sódicos, Rengasamy \& Olsson (1993) consideram que $\mathrm{Na}^{+}, \mathrm{NaHCO}_{3}, \mathrm{NaSO}_{4}^{-}, \mathrm{Mg}^{+2}$, $\mathrm{MgSO}_{4}, \mathrm{MgHCO}_{3}{ }^{+}, \mathrm{Ca}^{+2}, \mathrm{CaSO}_{4}, \mathrm{CaHCO}_{3}{ }^{+}$são as principais espécies que podem afetar a RAS da solução do solo. Em valores de $\mathrm{pH}$ entre 7,5 e 8,2 o $\mathrm{Ca}^{+2}$ pode precipitar no solo na forma de $\mathrm{CaCO}_{3}$ ou com o decréscimo do $\mathrm{pH}$ o composto precipitado pode ter sua solubilidade aumentada (Bouwer \& Chaney, 1974). Em valores de pH abaixo de 8,4 há predominância do íon bicarbonato $\left(\mathrm{HCO}_{3}{ }^{-}\right)$, enquanto acima desse valor predomina $\mathrm{o}$ íon carbonato $\left(\mathrm{CO}_{3}{ }^{2-}\right) . \mathrm{O} \mathrm{pH}$ do efluente de esgoto é ligeiramente alcalino, porém raramente atinge valores superiores a 8,4. A concentração de $\mathrm{HCO}_{3}{ }^{-}$no efluente de esgoto é muito superior que na água para abastecimento. A alcalinidade, determinada como $\mathrm{CaCO}_{3}$, varia de 200 a $700 \mathrm{mg} \mathrm{L}^{-1}$ (Feigin et al., 1991).

\section{Razão de adsorção de sódio (RAS)}

O grau de sodificação do solo depende da relação entre as concentrações de sódio e de íons polivalentes na solução do solo, relação que é normalmente medida pela RAS (razão de adsorção de sódio). Na prática, apenas os íons bivalentes são utilizados para calcular a RAS, porém, os íons trivalentes também devem ser considerados quando suas concentrações são significativas como ocorre em solos sódicos ácidos (Rengasamy \& Olsson, 1993).

A RAS tem sido utilizada na caracterização de solos sódicos e águas para irrigação e é calculada por meio da concentração de cátions em solução. A RAS é um

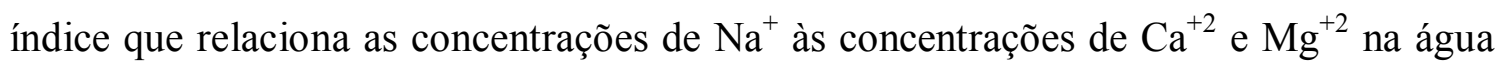
de irrigação, em extratos de saturação e extratos aquosos de solos e é calculada a partir da seguinte equação:

$$
R A S=\frac{N a^{+}}{\left[\left(C a^{++}+M g^{++}\right) / 2\right]^{0,5}}
$$

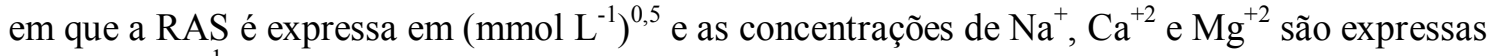
em $\mathrm{mmol}_{\mathrm{c}} \mathrm{L}^{-1}$. 
As concentrações de $\mathrm{Ca}^{2+}$ e $\mathrm{Mg}^{2+}$ nos efluentes de esgoto tratado normalmente são semelhantes àquelas encontradas na água de irrigação, sendo que o aumento das concentrações de $\mathrm{Ca}^{2+}$ e $\mathrm{Mg}^{2+}$ abaixa os valores de RAS melhorando a qualidade do efluente e da água de irrigação. Já os íons $\mathrm{HCO}_{3}{ }^{-}$e $\mathrm{CO}_{3}{ }^{2-}$ podem aumentar os riscos de sodicidade da água de irrigação por causarem a precipitação de carbonato de cálcio $\left(\mathrm{CaCO}_{3}\right)$ (Feigin et al., 1991).

Diversos procedimentos são utilizados para determinar a RAS. As atividades iônicas dos íons $\mathrm{Na}^{+}, \mathrm{Ca}^{+2} \mathrm{e} \mathrm{Mg}^{+2}$ são convenientemente usadas para calcular a RAS, a qual está relacionada à adsorção de sódio pelos colóides do solo. No entanto, por análises químicas da solução do solo são obtidas as concentrações totais de $\mathrm{Na}^{+}$, $\mathrm{Ca}^{+2}$ e $\mathrm{Mg}^{+2}$, as quais são utilizadas, na prática, no cálculo da RAS $\left(\mathrm{SAR}_{\mathrm{p}}\right.$-"pratical SAR"). Dados analíticos mostram que a RAS calculada a partir de atividades iônicas é maior que a calculada a partir das concentrações totais $(1,1$ a 1,2 vezes maior em solos com pH entre 5,5 e 7,0 e de 1,5 a 2,0 vezes maior em solos com pH maior que 8,0) (Rengasamy \& Olsson, 1993).

\section{Percentual de sódio trocável (PST)}

Diversas medidas de laboratório são utilizadas para a diagnose de problemas em solos salinos e sódicos. Além da RAS, são medidas importantes o pH e a CE de extrato aquoso e de saturação, bem como a determinação do PST a partir de análises químicas do solo. A CE de soluções é uma medida facilmente realizada no laboratório, apresentando uma relação linear com a concentração de sais em solução (Raij, 1991). O índice PST indica a proporção de sódio adsorvida no complexo de troca de cátions do solo e é determinado pela seguinte equação:

$$
P S T=\frac{N a_{t}}{C T C} \times 100
$$

onde:

- $N a_{t}=$ sódio trocável ou adsorvido, em $\mathrm{mmol}_{\mathrm{c}} \mathrm{dm}^{-3}$ ou $\mathrm{mmol}_{\mathrm{c}} \mathrm{kg}^{-1}$;

- CTC = capacidade de troca de cátions do solo $\left(\mathrm{Ca}, \mathrm{Mg}, \mathrm{Na}, \mathrm{K}, \mathrm{Al}\right.$ e H), em $\mathrm{mmol}_{\mathrm{c}} \mathrm{dm}^{-3}$ ou $\mathrm{mmol}_{\mathrm{c}} \mathrm{kg}^{-1}$. 
Valores limites de PST que causam deterioração da estrutura do solo podem variar. Em solos australianos, por exemplo, onde a adsorção de sódio nas superfícies das argilas excede $6 \%$ da capacidade de troca de cátions do solo (PST $=6 \%$ ), o solo é considerado sódico e está sujeito a degradações estruturais. O PST de valor $6 \%$ é baixo comparado com o valor $15 \%$ adotado pelo Laboratório de Salinidade dos Estados Unidos como indicador de deterioração da estrutura do solo (Rengasamy \& Olsson, 1991). Sumner (1993) relata que o valor de PST $>15$ adotado pelo Laboratório de Salinidade dos Estados Unidos foi baseado em medições de condutividade hidráulica utilizando água com concentração eletrolítica total muito elevada (3-10 $\left.\mathrm{mmol}_{\mathrm{c}} \mathrm{L}^{-1}\right)$ comparada à concentração eletrolítica da água utilizada em estudos australianos $\left(<0,7 \mathrm{mmol}_{\mathrm{c}} \mathrm{L}^{-1}\right)$. 


\section{MATERIAL E MÉTODOS}

A área experimental (Figura 2) representa uma área de $7.500 \mathrm{~m}^{2}$ inserida no campo experimental de Lins, onde diferentes projetos envolvendo o uso de EET na agricultura estão sendo desenvolvidos.

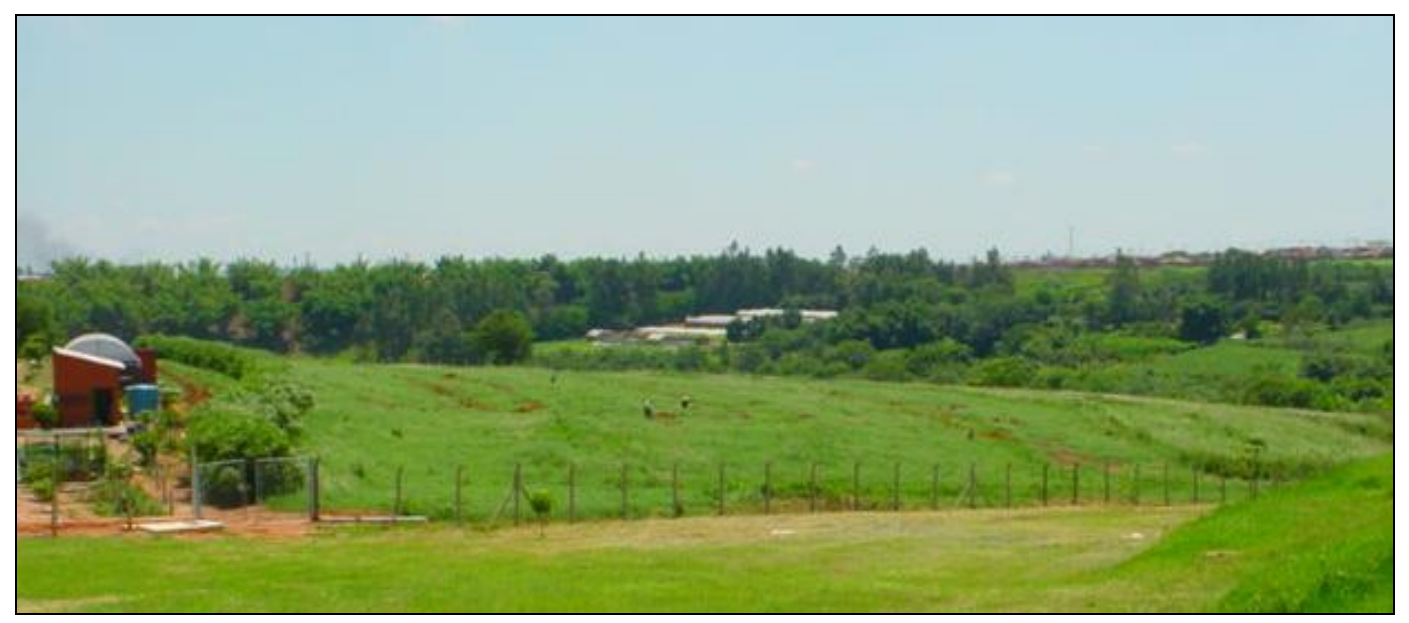

Figura 2 - Área experimental cultivada com capim-Tifton 85

O campo experimental de Lins (Figura 3) situa-se junto à estação de tratamentos de esgotos (ETE) operada pela Sabesp (Companhia de Saneamento Básico do Estados de São Paulo) na Unidade de Negócios do Baixo Tietê e Grande no município de Lins (SP) $\left(49^{\circ} 50^{\prime} \mathrm{W}\right.$ e $\left.22^{\circ} 21^{\prime} \mathrm{S}\right)$. O tratamento de esgoto é realizado por meio de lagoas de estabilização (Figura 3).

O sistema de tratamento de Lins é constituído de três lagoas anaeróbias (tratamento primário) seguidas de três lagoas facultativas (tratamento secundário), onde são produzidos cerca de $500 \mathrm{~m}^{3}$ hora $^{-1}$ de EET. As lagoas anaeróbias trabalham com tempo de detenção hidráulico médio de 5,0 dias (4,0 $\mathrm{m}$ de profundidade útil) e as lagoas facultativas com tempo de detenção hidráulico médio de 10,0 dias $(1,90 \mathrm{~m}$ de profundidade útil) (Piveli \& Doria, 2003). 


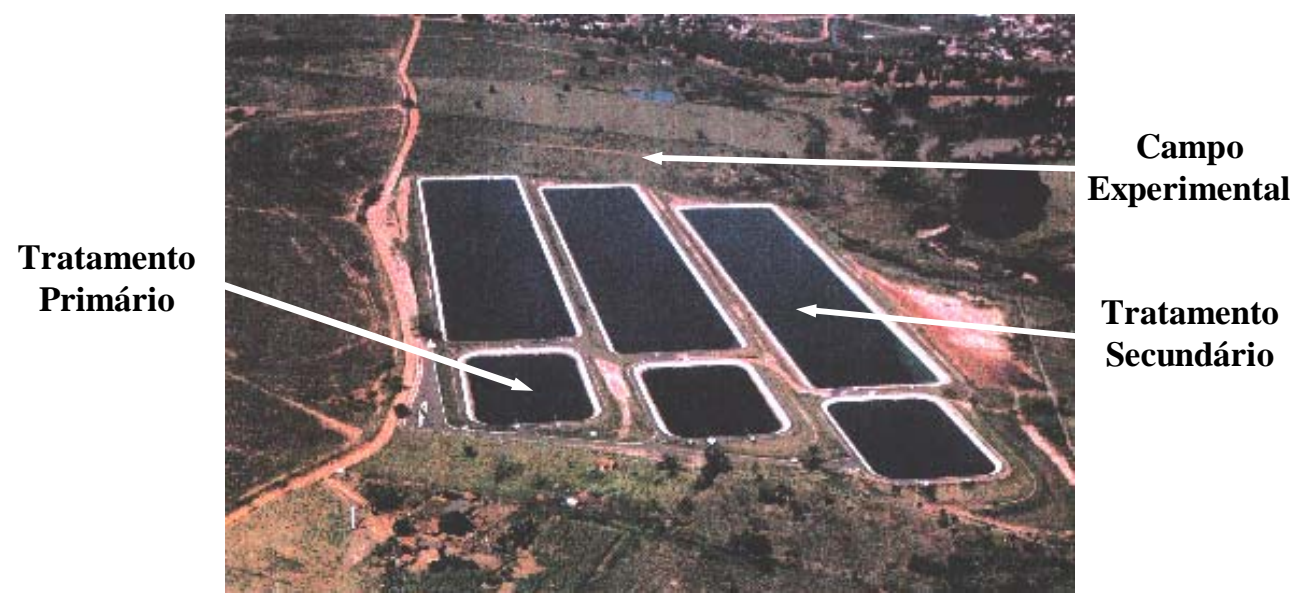

Figura 3 - Lagoas de estabilização operadas pela Sabesp em Lins (SP)

A área experimental foi cultivada com capim-Tifton 85 (Cynodon spp.). O capim-Tifton 85 é um cultivar desenvolvido na "Coastal Plain Experimente Station", da Universidade da Geórgia. É considerado o melhor híbrido obtido no programa de melhoramento desta Universidade dentre os híbridos de capins bermuda (Vilela \& Alvim, 1998). É uma planta perene, estolonífera e rizomatosa recomendada para fenação e para pastejo em decorrência da boa relação folha/colmo que possui, sendo aceita por eqüinos, bovinos, ovinos e caprinos (Rodrigues, et al. 1998).

O plantio do capim foi realizado em janeiro de 2002 sendo que previamente ao plantio, aplicaram-se $4000 \mathrm{~kg} \mathrm{ha}^{-1}$ de calcário dolomítico não sendo realizada qualquer fertilização. Desde então foram feitos apenas replantios, não sendo realizado corte do capim nem adubação pós-plantio até o início do experimento. O experimento teve início no mês janeiro de 2003 com o corte do capim na altura uniforme de $10 \mathrm{~cm}$ e implantação do sistema de irrigação por aspersão convencional.

O solo do campo experimental de Lins constitui, segundo Ibrahim (2002), um sistema LATOSSOLO-ARGISSOLO. Na área onde está instalado o experimento o solo foi classificado como um ARGISSOLO VERMELHO Distrófico de textura média argilosa. 


\subsection{Delineamento experimental e condução do experimento}

O delineamento experimental foi o de blocos completos casualizados em parcelas subdivididas no tempo com cinco tratamentos (A, E1 a E4) e quatro repetições (Figura 4). Cada unidade experimental possui $10 \mathrm{~m}$ de largura e $10 \mathrm{~m}$ de comprimento, com área total de $100 \mathrm{~m}^{2} \mathrm{e}$ área útil de $36 \mathrm{~m}^{2}$ (admitindo-se dois metros de bordadura). As parcelas foram distanciadas de $10 \mathrm{~m}$ para evitar a influência indesejável de tratamentos de parcelas adjacentes.

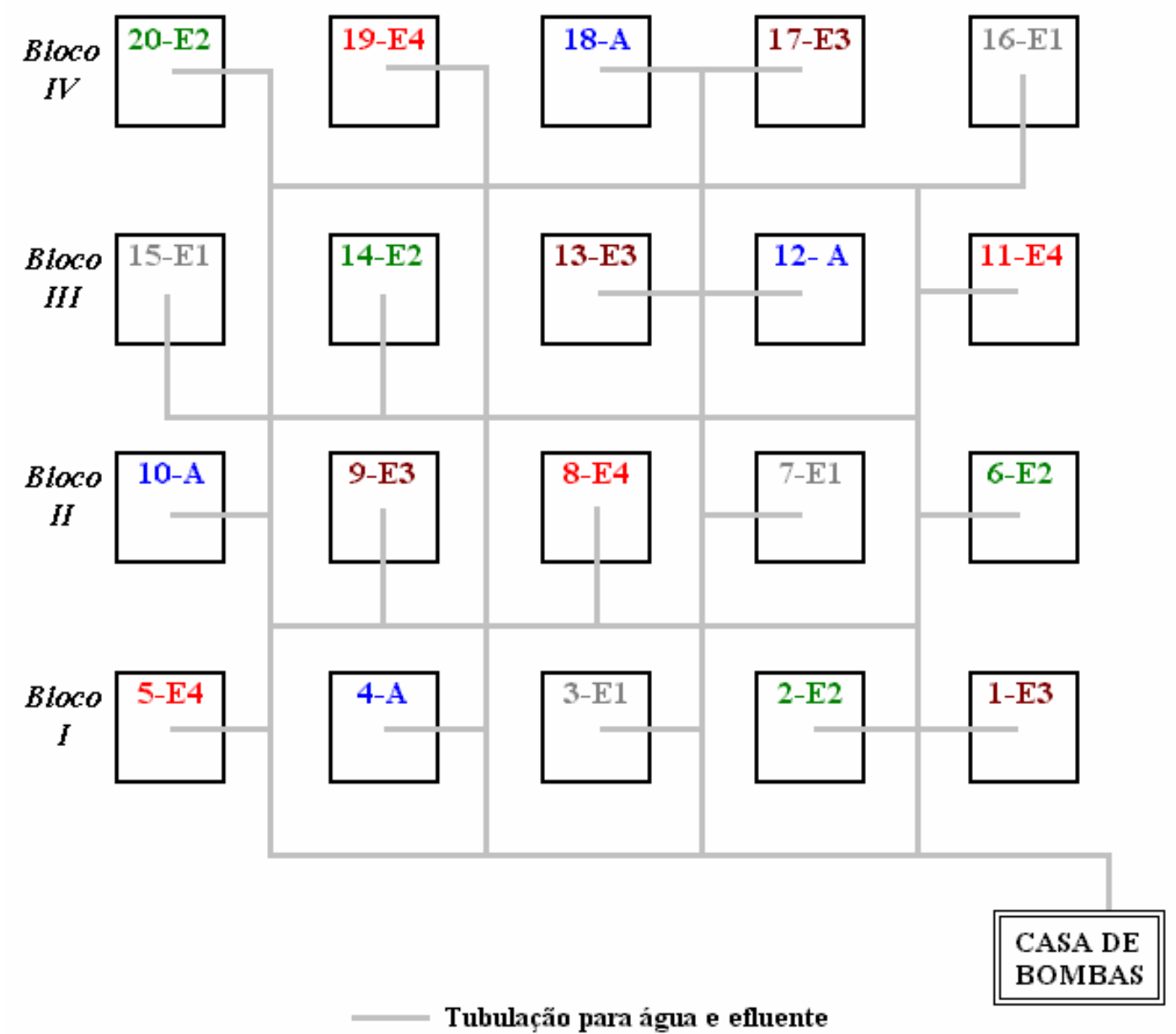

Figura 4 - Croqui do experimento indicando a distribuição dos tratamentos às parcelas experimentais 
O experimento foi idealizado para verificar o efeito da irrigação com efluente de esgoto tratado sobre o solo e sobre a produção do capim e compara-lo à irrigação com água e adubação convencional, situação real empregada em campo.

O objetivo do projeto maior que está sendo desenvolvido no Campo Experimental de Lins, no qual o presente estudo se insere, foi o de avaliar o potencial do efluente de esgoto em suprir a necessidade de nitrogênio da cultura. Levou-se em consideração o teor desse nutriente presente no efluente de esgoto e ainda o fato de que as forrageiras do gênero Cynodon (como é o caso do capim-Tifton 85) respondem muito bem à adubação nitrogenada (Vilela \& Alvim, 1998).

Os tratamentos empregados foram: A - irrigação com água e E1, E2, E3 e E4, irrigação com efluente de esgoto tratado. Para avaliar o potencial do efluente em fornecer nitrogênio ao capim, a fertilização mineral para este nutriente foi diferenciada entre os tratamentos durante o período experimental. As parcelas dos tratamentos A e E4 receberam quantidades iguais de fertilizante mineral (nitrato de amônio) para suprir $100 \%$ da necessidade de nitrogênio pela cultura. A fertilização nitrogenada foi diferenciada para os tratamentos E1, E2 e E3 que receberam, respectivamente, $0 \%, 33 \%$ e 66\% da quantidade necessária de nitrogênio para cultura (Tabela 3).

Em decorrência da fertização nitrogenada diferenciada, foram observados diferentes crescimentos do capim entre os tratamentos, sendo que, nos tratamentos onde foi maior o crescimento do capim, maior foi o volume de água ou de efluente adicionado via irrigação. As diferentes lâminas foram determinadas com base na manutenção de uma umidade do solo adequada para a cultura, com base em dados de umidade do solo obtidos pela utilização de tensiômetros instalados na área experimental, sendo que os

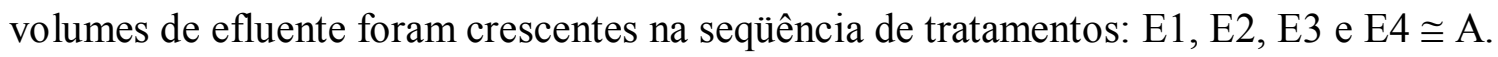
Em decorrência das diferentes lâminas aplicadas entre os tratamentos com efluente, foram adicionadas diferentes quantidades de $\mathrm{Na}^{+}$.

A fertilização mineral foi realizada conforme Werner et al. (1996) para gramíneas com objetivo de produção de feno (como é o caso do capim-Tifton 85), levando-se em consideração a produção de massa seca para recomendação de N e K e os 
resultados de análise de terra para recomendação de $\mathrm{P}$. A produção de massa seca do capim no início do experimento foi de $4754 \mathrm{~kg} \mathrm{ha}^{-1}$.

A partir do início do experimento as parcelas foram fertilizadas (Tabela 3) com fertilizantes minerais nitrogenado (nitrato de amônio), potássico (cloreto de potássio) e fosfatado (superfosfato simples) nas épocas de corte do capim (a cada 60 dias totalizando três épocas de corte). As quantidades de cloreto de potássio e superfosfato simples aplicadas foram iguais para todos os tratamentos visando manter o desenvolvimento adequado do capim, tendo em vista que a fertilidade do solo é o fator primordial para garantir o perfilhamento, a produção foliar e, conseqüentemente, a produção de massa seca de pastagens de Cynodon (Corsi \& Martha Júnior, 1998).

Tabela 3. Quantidades de fertilizantes minerais adicionados às parcelas durante o experimento

\begin{tabular}{|c|c|c|c|}
\hline Tratamentos & $\begin{array}{c}\text { Nitrato de Amônio } \\
\mathrm{kg} \mathrm{ha}^{-1} \text { de } \mathrm{N}\end{array}$ & $\begin{array}{c}\text { Superfosfato simples } \\
\mathrm{kg} \mathrm{ha}^{-1} \mathrm{de}_{2} \mathrm{P}_{5}\end{array}$ & $\begin{array}{c}\text { Cloreto de Potássio } \\
\mathrm{kg} \mathrm{ha}^{-1} \text { de } \mathrm{K}_{2} \mathrm{O}\end{array}$ \\
\hline \multicolumn{4}{|c|}{ Início do experimento (15/01/2003) } \\
\hline A & 60,0 & 100,0 & 40,0 \\
\hline E1 & 0,0 & 100,0 & 40,0 \\
\hline $\mathrm{E} 2$ & 19,8 & 100,0 & 40,0 \\
\hline E3 & 39,6 & 100,0 & 40,0 \\
\hline E4 & 60,0 & 100,0 & 40,0 \\
\hline \multicolumn{4}{|c|}{$1^{\circ}$ Corte $(15 / 03 / 2003)$} \\
\hline A & 60,0 & 0,0 & 40,0 \\
\hline E1 & 0,0 & 0,0 & 40,0 \\
\hline E2 & 19,8 & 0,0 & 40,0 \\
\hline E3 & 39,6 & 0,0 & 40,0 \\
\hline E4 & 60,0 & 0,0 & 40,0 \\
\hline \multicolumn{4}{|c|}{$2^{\circ}$ Corte (15/05/2003) } \\
\hline A & 120,0 & 0,0 & 100,0 \\
\hline E1 & 0,0 & 0,0 & 100,0 \\
\hline E2 & 39,6 & 0,0 & 100,0 \\
\hline E3 & 79,2 & 0,0 & 100,0 \\
\hline E4 & 120,0 & 0,0 & 100,0 \\
\hline \multicolumn{4}{|c|}{$3^{\circ}$ Corte $(16 / 07 / 2003)$} \\
\hline
\end{tabular}


O sistema de irrigação por aspersão convencional foi instalado em janeiro de 2003 com o início do experimento. Os aspersores foram dispostos nos centros das parcelas (Figura 5) e a uma altura aproximada de um metro da superfície do solo. Apresentam raio útil teórico de 2,0 a aproximadamente 5,5 m (Figura 5), vazão de $0,55 \mathrm{~m}^{3}$ hora $^{-1}$ e precipitação de $6,1 \mathrm{~mm}_{\text {hora }}{ }^{-1}$.

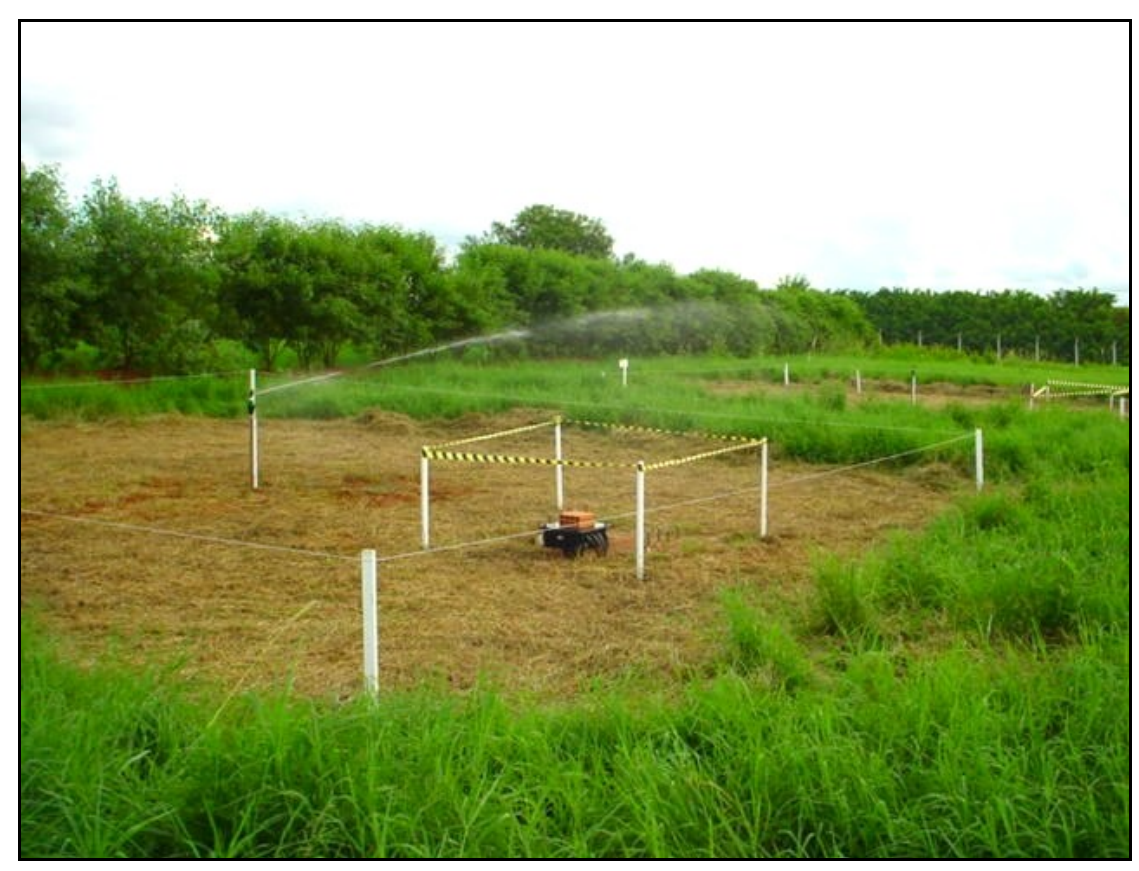

Figura 5 - Localização do aspersor no centro da parcela

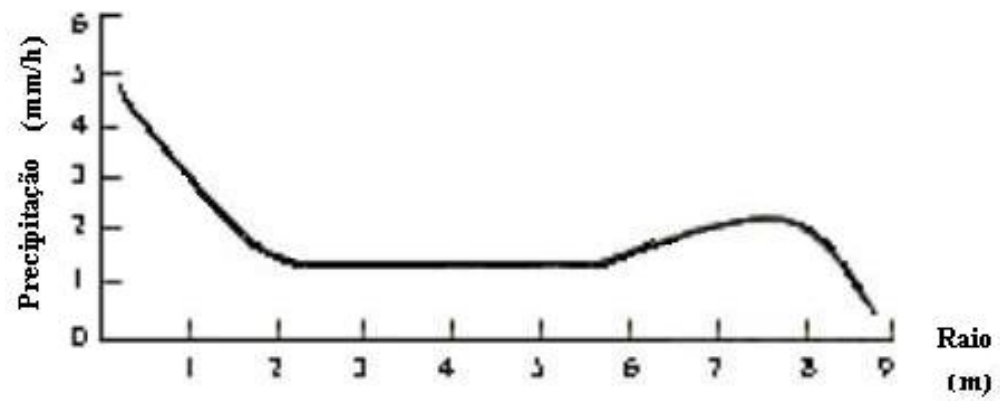

Figura 6 - Distribuição da precipitação e raio de alcance do aspersor segundo o fabricante 
As lâminas de água e efluente para irrigação foram determinadas com base na manutenção da umidade do solo necessária para o capim-Tifton 85. Adotou-se como critério de manejo da irrigação o estabelecimento de uma umidade crítica do solo na camada de 0 a $60 \mathrm{~cm}$. Esta umidade foi estabelecida em $70 \%$ do armazenamento total de água no solo, calculado pela equação:

$$
\begin{aligned}
& \qquad \mathrm{ARM}=\left(\theta_{\mathrm{CC}}-\theta_{\mathrm{PMP}}\right) \cdot 10 . \mathrm{z} \\
& \text { em que, } \\
& \mathrm{ARM}=\text { armazenamento de água no solo, } \mathrm{mm} ; \\
& \theta_{\mathrm{CC}}=\text { umidade volumétrica do solo à capacidade de campo, } \mathrm{cm}^{3} \cdot \mathrm{cm}^{-3} ; \\
& \theta_{\mathrm{PMP}}=\text { umidade volumétrica do solo ao ponto de murcha permanente, } \mathrm{cm}^{3} \mathrm{~cm}^{-3} ; \\
& \mathrm{z}=\text { profundidade efetiva do sistema radicular, } \mathrm{cm} .
\end{aligned}
$$

Quando as leituras nos tensiômetros indicavam que a umidade estava igual ou abaixo da umidade crítica realizava-se a irrigação com água ou efluente. As leituras nos tensiômetros foram realizadas a cada dois dias em todas as parcelas, no entanto, para cada tratamento, a lâmina a ser irrigada era determinada com base na maior leitura (correspondente à menor umidade do solo) realizada entre as quatro parcelas. Os tensiômetros (Figura 7) foram instalados em todas as parcelas nas camadas A $(0-20 \mathrm{~cm})$, B $(20-40 \mathrm{~cm}), \mathrm{C}(40-60 \mathrm{~cm}), \mathrm{D}(60-80 \mathrm{~cm})$ e E $(80-100 \mathrm{~cm})$.

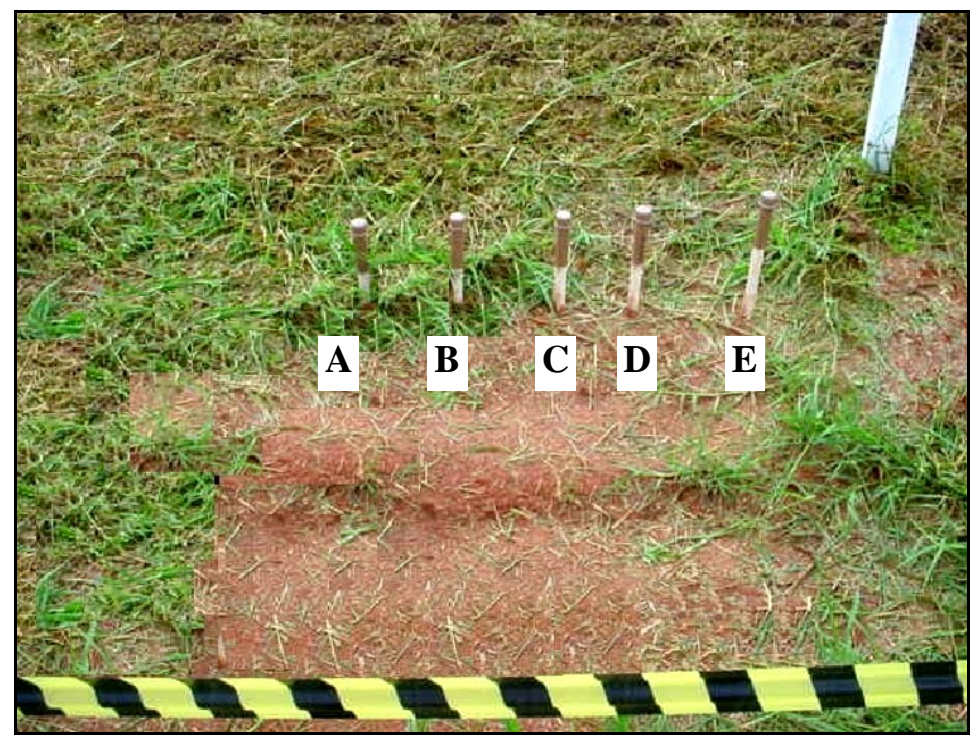

Figura 7 - Conjunto de tensiômetros instalados em diferentes camadas do solo 


\subsection{Coleta de amostras de água, efluente, terra, capim e obtenção da solução do solo}

Água e efluente

Amostras de água e efluente utilizados para irrigação no experimento foram coletadas mensalmente (de janeiro a julho de 2003). As coletas foram efetuadas junto às saídas de água e efluente para a tubulação do sistema de irrigação. As amostras coletadas foram encaminhadas para o laboratório do Núcleo de Pesquisa em Geoquímica e Geofísica da Litosfeta (Nupegel) / USP onde foram preparadas para às determinações analíticas.

\section{Terra}

Antes da instalação do experimento, foram coletadas amostras de terra para análise física e química do solo para fins de caracterização da área experimental. Durante a condução do experimento foram realizadas amostragens de terra nos meses de abril e julho de 2003 para análises química e física em todas as parcelas e camadas estudadas.

As amostras foram obtidas com trado holandês nas camadas: 0-10, 10-20, 20-40, 40-60, 60-80 e 80-100 cm. Os pontos de retirada de subamostras na parcela foram dispostos na faixa de 2 a 3 metros a partir do aspersor situado no centro da parcela. Esta faixa (área útil) situa-se na região de maior uniformidade de precipitação dos aspersores (Figura 6). Foi retirada, em cada parcela, uma amostra composta de terra por camada. Para as camadas 0-10 e 0-20 cm a amostra composta foi constituída de 12 subamostras enquanto que 6 subamostras constituíram as amostras compostas das demais camadas. As amostras foram colocadas em sacos plásticos previamente identificados e encaminhadas para preparo e análises.

\section{Capim}

O corte do capim foi realizado manualmente a cada 60 dias nos meses de março, maio e julho, em área útil de $1 \mathrm{~m}^{2}$, na porção de maior uniformidade de 
precipitação do aspersor em cada parcela (Figura 6) para a determinação da produção de massa seca. Após o corte, as amostras de capim foram lavadas com água deionizada, armazenadas em sacos de papel previamente identificados e, posteriormente, encaminhadas para secagem. Depois de realizado o corte para determinação da massa seca, o capim foi cortado mecanicamente em toda a área experimental a uma altura de 10 cm e, em seguida, realizou-se a fertilização mineral (Tabela 3).

\section{Solução do solo}

A solução do solo (extrato de saturação) foi obtida a partir das amostras de terra, para as seis camadas e para as duas épocas de amostragem (abril e julho) mediante a aplicação de vácuo em amostras de terra umedecidas com água deionizada, conforme metodologia proposta em Embrapa (1997) e Raij et al. (2001).

\subsection{Preparo de amostras e análises de água, efluente e solução do solo}

As análises foram realizadas nos laboratórios do Departamento de Solos e Nutrição de Plantas / ESALQ e do NUPEGEL / USP.

Primeiramente determinaram-se nas amostras brutas de água, efluente e solução do solo, o pH e a $\mathrm{CE}$ empregando-se, respectivamente, pHmetro e condutivímetro digital. Após as leituras, as amostras brutas foram filtrados em membranas de éster-celulose com diâmetro de poro de $0,22 \mu \mathrm{m}$. Os volumes filtrados foram preservados com solução $\mathrm{HgCl}_{2} 1 \mathrm{~g} \mathrm{~L}^{-1}$.

Depois de preservadas as amostras foram submetidas às determinações dos teores de $\mathrm{Ca}, \mathrm{Mg}, \mathrm{K}, \mathrm{Na}$ e $\mathrm{Al}$ e alcalinidade (como $\mathrm{HCO}_{3}{ }^{-}$). A alcalinidade foi determinada por titulação acidimétrica (Embrapa, 1997) empregando-se a solução de $\mathrm{H}_{2} \mathrm{SO}_{4}$ 0,025 mol L ${ }^{-1}$. Os elementos $\mathrm{Ca}, \mathrm{Mg}, \mathrm{K}$ e $\mathrm{Al}$ foram determinados na água, no efluente e na solução do solo, pelo método instrumental Espectrometria de Emissão Óptica com Plasma de Argônio Acoplado Indutivamente e o cátion $\mathrm{Na}^{+}$por Fotometria de Emissão em Chama. 


\subsection{Preparo de amostras e análise de terra}

As análises químicas e físicas de terra foram realizadas nos laboratórios do Departamento de Solos e Nutrição de Plantas/ESALQ, do Nupegel/USP e da Embrapa Meio Ambiente.

As amostras coletadas foram secas ao ar e passadas por peneira de malha $2 \mathrm{~mm}$ obtendo-se a fração terra fina seca ao ar (TFSA) para análises química e física. As amostras assim preparadas foram submetidas às determinações de $\mathrm{pH}$ e acidez potencial ( $\mathrm{H}+\mathrm{Al}$ ) utilizando-se o método proposto em Raij et al. (2001). Os teores de Na, $\mathrm{K}, \mathrm{Ca}, \mathrm{Mg}$ e Al trocáveis obtidos conforme Embrapa (1999) e as determinações das frações granulométricas (areia, silte e argila) e argila dispersa em água (ADA) foram realizadas pelo método da pipeta (Camargo et al., 1986).

$\mathrm{O} \mathrm{pH}$ foi determinado em solução de $\mathrm{CaCl}_{2} \quad 0,01 \mathrm{~mol} \mathrm{~L}^{-1}$ na relação solo:solução igual a 1:2,5 (m:v). Os elementos $\mathrm{Ca}$ e $\mathrm{Mg}$ e Al foram extraídos com solução de KCL $1 \mathrm{~mol} \mathrm{~L}^{-1}$ na relação solo:solução de 1:10 (m:v). As concentrações dos cátions $\mathrm{Ca}$ e $\mathrm{Mg}$ foram obtidas empregando-se o método instrumental Espectrofotometria de Absorção Atômica. A concentração de Al foi obtida por titulação com solução $\mathrm{NaOH} 0,025 \mathrm{~mol} \mathrm{~L}^{-1}$.

A extração de $\mathrm{H}+\mathrm{Al}$ (acidez potencial) foi realizada com solução de acetado de cálcio $0,5 \mathrm{M}$ a pH 7,0, na relação solo:solução de 1:10 (m:v). A concentração de $\mathrm{H}+\mathrm{Al}$ foi obtida por titulação com solução $\mathrm{NaOH} 0,025 \mathrm{~mol} \mathrm{~L}^{-1}$. Para a extração de $\mathrm{Na}$ e K utilizou-se a solução Mehlich-1 $\left(\mathrm{HCl}\right.$ 0,05 mol L $\left.{ }^{-1}+\mathrm{H}_{2} \mathrm{SO}_{4} 0,0125 \mathrm{~mol} \mathrm{~L}^{-1}\right)$ na relação solo:solução de 1:10 (m:v). A determinação das concentrações para ambos os cátions foi realizada por meio do método instrumental Fotometria de Emissão em Chama.

As frações granulométricas foram determinadas apenas nas amostras obtidas na primeira época de amostragem (março). A solução dispersante utilizada foi a combinação das soluções hidróxido de sódio e hexametafosfato de sódio. A fração "areia" foi obtida por peneiramento da solução solo+dispersante em peneira de malha $0,053 \mathrm{~mm}$, sendo que a fração retida correspondeu à fração "areia". A fração argila foi 
obtida após pipetagem de uma alíquota da solução solo+dispersante após sedimentação do silte. A fração silte foi obtida por diferença conhecendo-se o peso das demais frações e o peso total da TFSA utilizada.

A fração ADA foi obtida para os dois períodos de amostragem (março e julho). Trata-se da determinação da fração de partículas do solo com diâmetro inferior a 0,002 mm, obtida com a dispersão em água destilada, na ausência de eletrólitos. A fração ADA foi obtida por pipetagem de alíquota da solução solo+água após sedimentação das demais frações.

\subsection{Determinação da produção de massa seca do capim-Tifton 85}

Após o corte todo o material foi seco em estufa com circulação forçada de ar a $60^{\circ} \mathrm{C}$ até atingir massa constante. Em seguida efetuou-se a pesagem de todo o material para determinação da produção de massa seca do capim.

\subsection{Análises estatísticas}

Os resultados foram submetidos à análise de variância de acordo com o modelo de experimento de blocos completos casualizados com parcelas subdivididas no tempo. Nos casos de F significativo aplicou-se o teste de Tukey a $5 \%$ de probabilidade. O programa utilizado para análise dos dados foi programa estatístico Sanest para DOS.

As variáveis originadas a partir de análise química e física de terra foram obtidas em duas épocas de amostragem (meses de abril e julho), enquanto que a variável "massa seca" do capim foi obtida em 3 épocas de amostragem (março, maio e julho). 


\section{RESULTADOS E DISCUSSÃO}

A seguir são apresentados os resultados das análises químicas de água, efluente, solução do solo, terra e produção de massa seca do capim.

\subsection{Qualidade do efluente de esgoto tratado e da água de irrigação}

A qualidade da água e do efluente de esgoto foi monitorada de janeiro a julho de 2003, sendo os resultados apresentados na Tabela 4

Tabela 4. Resultados de análises químicas da água e do efluente de esgoto utilizados para irrigação do capim-Tifton de janeiro a julho de 2003

\begin{tabular}{|c|c|c|c|c|c|c|c|c|}
\hline \multirow[t]{2}{*}{ Constituintes } & \multicolumn{8}{|c|}{ Meses } \\
\hline & Janeiro & Fevereiro & Março & Abril & Maio & Junho & Julho & Media \\
\hline & \multicolumn{8}{|c|}{ Água } \\
\hline $\mathrm{pH}$ & 9,57 & 10,15 & 9,89 & 9,63 & 9,79 & 9,75 & 9,65 & 9,78 \\
\hline $\left.\mathrm{CE}(\mathrm{dS} \mathrm{m})^{-1}\right)^{(1)}$ & 0,47 & 0,46 & 0,48 & 0,37 & 0,49 & 0,53 & 0,45 & 0,46 \\
\hline$\left(\mathrm{HCO}_{3}^{-}\right)\left(\mathrm{mmol}_{\mathrm{c}} \mathrm{L}^{-1}\right)^{(2)}$ & 3,75 & 4,00 & 3,75 & 3.75 & 4,25 & 4,25 & 4,25 & 4,04 \\
\hline $\mathrm{Na}\left(\mathrm{mmol}_{\mathrm{c}} \mathrm{L}^{-1}\right)$ & 7,75 & 7,62 & 8,67 & 7,45 & 7,88 & 5,78 & 4,47 & 6,80 \\
\hline $\mathrm{K}\left(\mathrm{mmol}_{\mathrm{c}} \mathrm{L}^{-1}\right)$ & 0,02 & 0,02 & 0,02 & 0,02 & 0,03 & 0,02 & 0,02 & 0,02 \\
\hline $\mathrm{Ca}\left(\mathrm{mmol}_{\mathrm{c}} \mathrm{L}^{-1}\right)$ & 0,03 & 0,03 & 0,03 & 0,07 & 0,05 & 0,03 & 0,03 & 0,04 \\
\hline $\operatorname{Mg}\left(\mathrm{mmol}_{\mathrm{c}} \mathrm{L}^{-1}\right)$ & 0,03 & 0,02 & 0,03 & 0,02 & 0,03 & 0,02 & 0,02 & 0,02 \\
\hline $\mathrm{Al}\left(\mathrm{mg} \mathrm{L}^{-1}\right)^{(3)}$ & nd ${ }^{(3)}$ & nd & nd & nd & nd & nd & nd & - \\
\hline \multirow[t]{2}{*}{$\left.\operatorname{RAS}(\mathrm{mmol} \mathrm{L})^{-1}\right)^{0,5}$} & 45 & 48 & 50 & 35 & 39 & 37 & 28 & 40 \\
\hline & \multicolumn{8}{|c|}{ Efluente } \\
\hline PH & 7,34 & 7,37 & 7,88 & 7,19 & 7,27 & 7,42 & 7,01 & 7,35 \\
\hline $\left.\mathrm{CE}(\mathrm{dS} \mathrm{m})^{-1}\right)^{(1)}$ & 0,48 & 0,77 & 0,77 & 0,87 & 0,94 & 1,03 & 0,88 & 0,82 \\
\hline$\left(\mathrm{HCO}_{3}^{-}\right)\left(\mathrm{mmol}_{\mathrm{c}} \mathrm{L}^{-1}\right)^{(2)}$ & 3,50 & 5,25 & 5,25 & 5,00 & 5,25 & 4,25 & 5,50 & 4,86 \\
\hline $\mathrm{Na}\left(\mathrm{mmol}_{\mathrm{c}} \mathrm{L}^{-1}\right)$ & 6,83 & 8,28 & 8,02 & 8,67 & 8,94 & 5,78 & 6,31 & 7,55 \\
\hline $\mathrm{K}\left(\mathrm{mmol}_{\mathrm{c}} \mathrm{L}^{-1}\right)$ & 0,25 & 0,41 & 0,38 & 0,42 & 0,42 & 0,32 & 0,52 & 0,39 \\
\hline $\mathrm{Ca}\left(\mathrm{mmol}_{\mathrm{c}} \mathrm{L}^{-1}\right)$ & 0,34 & 0,37 & 0,43 & 0,34 & 0,39 & 0,41 & 0,43 & 0,39 \\
\hline $\operatorname{Mg}\left(\mathrm{mmol}_{\mathrm{c}} \mathrm{L}^{-1}\right)$ & 0,17 & 0,17 & 0,20 & 0,17 & 0,12 & 0,14 & 0,10 & 0,15 \\
\hline $\mathrm{Al}\left(\mathrm{mg} \mathrm{L}^{-1}\right)$ & nd & nd & nd & nd & nd & nd & nd & - \\
\hline $\operatorname{RAS}\left(\mathrm{mmol} \mathrm{L}^{-1}\right)^{0,5}$ & 14 & 16 & 14 & 17 & 18 & 11 & 12 & 15 \\
\hline
\end{tabular}


Com base na caracterização de efluentes secundários domésticos citada em Feigin et al. (1991) (Tabela 1), observa-se que os valores de $\mathrm{pH}$ encontrados para o efluente de Lins (Tabela 4) permaneceram muito próximos à faixa de 7,8 a 8,1, normalmente verificada para efluentes. As concentrações de $\mathrm{Na}$ e $\mathrm{K}$ e Ca no efluente estiveramm dentro das variações esperadas $\left(2,17-10,87 ; 0,25-1,02,0,25-1,50\right.$ mmol $_{\mathrm{c}} \mathrm{L}^{-1}$, respectivamente), o que não ocorreu para os elementos $\mathrm{Mg}$ que se manteve abaixo da variação esperada $\left(0,21-1,03\right.$ mmol $\left._{\mathrm{c}} \mathrm{L}^{-1}\right)$. Os valores de RAS do efluente permaneceram acima em, no mínimo, 3 unidades do limite máximo $(7,9)$ normalmente encontrado para efluentes.

Os resultados das análises químicas de água e de efluente (Tabela 4) foram comparados às diretrizes de qualidade d'água para irrigação, conforme Ayers \& Westcot (1985).

Tabela 5. Graus de restrição para o uso da água e do efluente de esgoto tratado para irrigação de culturas por aspersão conforme Ayers \& Westcot (1985)

\begin{tabular}{|c|c|c|c|c|c|c|c|c|}
\hline \multirow[t]{2}{*}{ Parâmetros } & & \multicolumn{7}{|c|}{ Graus de restrição para uso em irrigação } \\
\hline & & Janeiro & Fevereiro & Março & Abril & Maio & Junho & Julho \\
\hline $\mathrm{CE}\left(\mathrm{dS} \mathrm{m} \mathrm{m}^{-1}\right)$ & $\begin{array}{l}\text { Água } \\
\text { Efluente }\end{array}$ & $\begin{array}{l}\mathrm{SR}^{(1)} \\
\mathrm{SR}\end{array}$ & $\begin{array}{c}\text { SR } \\
\text { B-M }^{(2)}\end{array}$ & $\begin{array}{l}\text { Salinic } \\
\text { SR } \\
\text { B-M }\end{array}$ & $\begin{array}{l}\text { de } \\
\text { SR } \\
\text { B-M }\end{array}$ & $\begin{array}{c}\text { SR } \\
\text { B-M }\end{array}$ & $\begin{array}{c}\text { SR } \\
\text { B-M }\end{array}$ & $\begin{array}{c}\text { SR } \\
\text { B-M }\end{array}$ \\
\hline $\begin{array}{l}\text { RAS }\left(\mathrm{mmol} \mathrm{L}^{-1}\right)^{0,5} \\
\text { e CE }\end{array}$ & $\begin{array}{l}\text { Água } \\
\text { Efluente }\end{array}$ & $\begin{array}{l}\mathrm{SV}^{(3)} \\
\mathrm{SV}\end{array}$ & $\begin{array}{l}\quad \text { Infilt } \\
\text { SV } \\
\text { SV }\end{array}$ & $\begin{array}{c}\text { lção de } \\
\text { SV } \\
\text { SV }\end{array}$ & $\begin{array}{l}\text { SV no s } \\
\text { SV }\end{array}$ & $\begin{array}{l}\text { o } \\
\text { SV } \\
\text { SV }\end{array}$ & $\begin{array}{l}\text { SV } \\
\text { SV }\end{array}$ & $\begin{array}{l}\mathrm{SV}^{-} \\
\mathrm{SV}\end{array}$ \\
\hline $\mathrm{Na}\left(\mathrm{mmol}_{\mathrm{c}} \mathrm{L}^{-1}\right)$ & $\begin{array}{l}\text { Água } \\
\text { Efluente }\end{array}$ & $\begin{array}{l}\text { B-M } \\
\text { B-M }\end{array}$ & $\begin{array}{l}\text { oxicidade d } \\
\text { B-M } \\
\text { B-M }\end{array}$ & $\begin{array}{l}\text { íons (cu } \\
\text { B-M } \\
\text { B-M }\end{array}$ & $\begin{array}{l}\text { uras sus } \\
\text { B-M } \\
\text { B-M }\end{array}$ & $\begin{array}{l}\text { tíveis) } \\
\text { B-M } \\
\text { B-M }\end{array}$ & $\begin{array}{l}\text { B-M } \\
\text { B-M }\end{array}$ & $\begin{array}{l}\text { B-M } \\
\text { B-M }\end{array}$ \\
\hline $\mathrm{pH}$ & $\begin{array}{l}\text { Água } \\
\text { Efluente }\end{array}$ & $\begin{array}{l}\mathrm{AN}^{(4)} \\
\mathrm{N}^{(5)}\end{array}$ & $\begin{array}{l}\text { feitos dive } \\
\text { AN } \\
\text { N }\end{array}$ & $\begin{array}{l}\text { os (cultt } \\
\text { AN } \\
\text { N }\end{array}$ & $\begin{array}{c}\text { as susce } \\
\text { AN } \\
\text { N }\end{array}$ & $\begin{array}{c}\text { veis) } \\
\text { AN } \\
\text { N }\end{array}$ & $\begin{array}{c}\text { AN } \\
\mathrm{N}\end{array}$ & $\begin{array}{l}\mathrm{AN} \\
\mathrm{N}\end{array}$ \\
\hline $\mathrm{HCO}_{3}^{-}\left(\mathrm{mmol}_{\mathrm{c}} \mathrm{L}^{-1}\right)$ & $\begin{array}{l}\text { Água } \\
\text { Efluente }\end{array}$ & $\begin{array}{l}\text { B-M } \\
\text { B-M }\end{array}$ & $\begin{array}{l}\text { B-M } \\
\text { B-M }\end{array}$ & $\begin{array}{l}\text { B-M } \\
\text { B-M }\end{array}$ & $\begin{array}{l}\text { B-M } \\
\text { B-M }\end{array}$ & $\begin{array}{l}\text { B-M } \\
\text { B-M }\end{array}$ & $\begin{array}{l}\text { B-M } \\
\text { B-M }\end{array}$ & $\begin{array}{l}\text { B-M } \\
\text { B-M }\end{array}$ \\
\hline $\begin{array}{l}\text { (1) Sem restrição, (C } \\
\text { (2) grau de restrição } \\
\text { (3) grau de restrição } \\
\text { água } \Rightarrow \text { RAS: } 20\end{array}$ & $\begin{array}{l}\text { "E: }<0,7) \text {; } \\
\text { "baixo a } 1 \\
\text { "severo", }\end{array}$ & luent & RAS: 6 & e CE: & $\begin{array}{l}\mathrm{HCO} \\
, 5 ; \mathrm{R}\end{array}$ & $\begin{array}{l}5 \mathrm{a} \\
12 \mathrm{a}\end{array}$ & CE: 2 & a 1,3 ; \\
\hline
\end{tabular}


${ }^{(5)}$ valores dentro da faixa de variação normal.

Considerando o possível problema de salinização do solo, o efluente de esgoto apresentou grau de restrição "baixo a moderado" em todos os meses de irrigação, com exceção do mês de janeiro no qual este não apresentou grau de restrição para uso. Para capins bermuda (como é o caso do capim-Tifton 85), a salinidade da água e do efluente não oferece risco à produtividade, uma vez que, para um rendimento máximo (100\%) a condutividade elétrica da água não deveria ultrapassar 4,6 $\mathrm{dS} \mathrm{m}^{-1}$ (Tabela 6), Nesse sentido, capins bermuda são considerados tolerantes à salinidade (Maas, 1984).

Tabela 6. Tolerância ${ }^{(1)}$ de capins bermuda (Cynodon dactylon) em relação à salinidade do solo $(\mathrm{CEe})^{(2)}$ e da água de irrigação $(\mathrm{CEa})^{(3)}$, com base no percentual de rendimento (adaptado de Ayers \& Westcot, 1985)

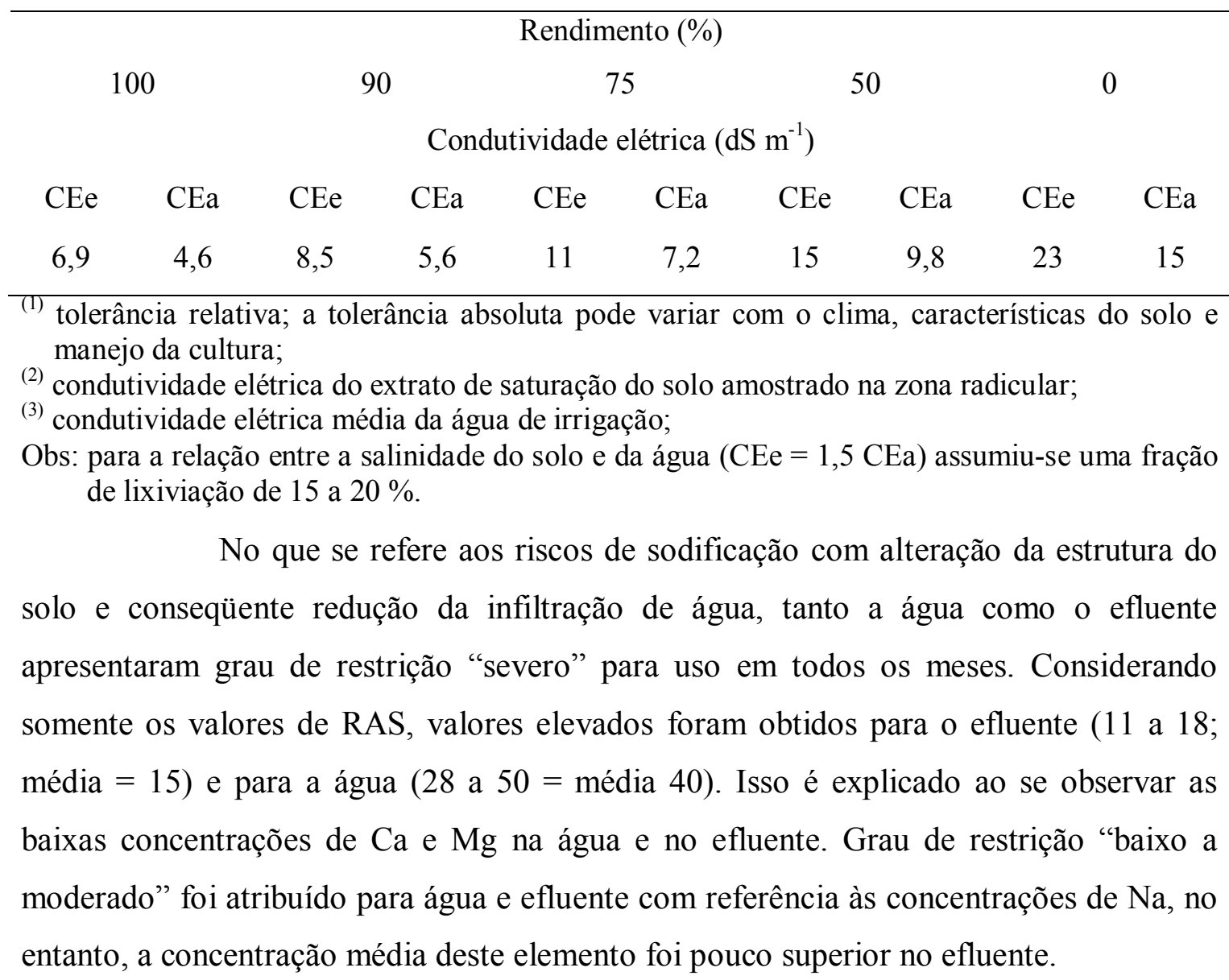


Em todos os meses a água utilizada para irrigação apresentou valores elevados de $\mathrm{pH}$ e maiores do que os obtidos para o efluente. Isso evidencia o caráter alcalino da água durante todo o período de irrigação. Com base nos graus de restrição estabelecidos (Tabela 5), todos os valores de $\mathrm{pH}$ para a água permaneceram acima da faixa de variação considerada normal para águas de irrigação ao contrário do que foi observado para o efluente em que os valores de $\mathrm{pH}$ se enquadraram na faixa normal. Quanto à alcalinidade como $\mathrm{HCO}_{3}{ }^{-}$, o grau de restrição de uso da água e do efluente foi "baixo a moderado" em todos os meses, no entanto, o valor médio da alcalinidade do efluente foi um pouco superior ao valor obtido para a água.

Os diferentes volumes de irrigação entre os tratamentos (Tabela 7) foram devido ao crescimento diferenciado do capim decorrente da fertilização nitrogenada realizada durante o período experimental (Tabela 3). Nota-se que, ao final do experimento, os volumes de efluente adicionados foram crescentes na seguinte ordem de tratamentos: E1, E2, E3 e E4. Os maiores volumes de irrigação foram adicionados às parcelas sob os tratamentos $\mathrm{A}$ e E4, não havendo considerável diferença entre esses volumes.

Tabela 7. Volumes de água e efluente adicionados via irrigação durante o período experimental

\begin{tabular}{ccccccccc}
\hline \multirow{2}{*}{ Tratamentos } & $(1)$ & \multicolumn{7}{c}{ Volume irrigado, mm } \\
& Janeiro & Fevereiro & Março & Abril & Maio & Junho & Julho & Total \\
\hline A & 0,0 & 4,2 & 21,3 & 29,2 & 19,9 & 48,4 & 86,1 & 209,0 \\
E1 & 0,0 & 3,0 & 15,1 & 20,7 & 20,1 & 20,7 & 61,1 & 140,6 \\
E2 & 0,0 & 3,1 & 15,7 & 21,6 & 23,4 & 24,9 & 70,4 & 159,2 \\
E3 & 0,0 & 3,4 & 17,0 & 23,4 & 20,6 & 38,9 & 69,1 & 172,3 \\
E4 & 0,0 & 4,0 & 20,7 & 27,7 & 27,0 & 46,1 & 81,8 & 207,2 \\
\hline (1) A (água +100 \% de N); E1 (efluente+0 \% de N), E2 (efluente+33 \% de N); E3 (efluente+66 \% \\
de N), E4 (efluente+100 \% de N)
\end{tabular}

Considerando os diferentes volumes de irrigação entre os tratamentos (Tabela 7) e as concentrações médias dos elementos durante o experimento (Tabela 4), diferentes quantidades de elementos do efluente e da água foram adicionadas às parcelas. Para todos os elementos, as maiores quantidades adicionadas ao solo ocorreram para o tratamento E4, enquanto que as menores quantidades adicionadas, com exceção 
da alcalinidade como $\mathrm{HCO}_{3}{ }^{-}$e do $\mathrm{Na}^{+}$, foram observadas para o tratamento A. Portanto, nota-se que o efluente, além de ser fonte de água para o capim, contribui para o aporte de elementos como $\mathrm{Na}, \mathrm{K}, \mathrm{Ca}$ e $\mathrm{Mg}$ no solo. Em longos períodos de irrigação, ao contrário do que ocorreu neste estudo, o aporte desses nutrientes no solo poderá contribuir para a nutrição de plantas (Bouwer \& Chaney, 1974; Johns \& McConchie, 1994; Oron, 1996, Yadav, et al., 2002; Kouraa et al., 2002).

Um fato indesejável foi a adição de maiores quantidades de $\mathrm{Na}$ e do aumento da alcalinidade (como $\mathrm{HCO}_{3}{ }^{-}$) do solo sob irrigação com efluente (tratamento E4). Como já foi abordado no item 2.2.1.2. a alcalinidade da solução do solo uma vez aumentada, em decorrência da qualidade da água de irrigação, pode resultar na presença

de ânions como $\mathrm{HCO}_{3}{ }^{-}$e $\mathrm{CO}_{3}{ }^{2-}$ que podem aumentar os efeitos negativos do sódio para o solo ao formarem compostos estáveis com $\mathrm{Ca}$ e $\mathrm{Mg}$ (Richards, 1954; Feigin et al., 1991).

\subsection{Efeitos da irrigação com efluente de esgoto e com água sobre o solo}

Nas Tabelas 8 e 9 são apresentados, respectivamente, os resultados das análises química e física do solo para fins de caracterização geral da área previamente à instalação do experimento. Com base nos resultados (Tabela 8), nota-se que o solo caracterizava-se por baixa capacidade de troca de cátions (CTC), baixa saturação por bases. Apresentava ainda baixos teores de $\mathrm{Ca}, \mathrm{K}$ e $\mathrm{Na}$ e teores médios de $\mathrm{Mg}$ (Raij, 1991).

A textura das camadas de solo estudadas foram classificadas como "franco arenosa" de 0 a $40 \mathrm{~cm}$ e como "franco argilo arenoso" de 40 a $100 \mathrm{~cm}$ do solo (Tabela 9). A mudança textural abrupta, característica do solo estudado, foi evidenciada aos $40 \mathrm{~cm}$ de profundidade de acordo com a variação da fração argila no perfil. Com base nos valores de grau de dispersão (GD) das argilas das camadas, nota-se que a maior parte das argilas encontrava-se floculada. 
Tabela 8. Resultados de análise química para caracterização do solo previamente à instalação do experimento

\begin{tabular}{|c|c|c|c|c|c|c|c|c|c|c|c|c|c|c|c|c|c|}
\hline Camadas & & $\mathrm{pH}$ & & $\mathrm{MO}^{(1)}$ & $\mathrm{P}$ & $\mathrm{H}+\mathrm{Al}$ & $\mathrm{Al}^{+3}$ & $\mathrm{Ca}^{+2}$ & $\mathrm{Mg}^{+2}$ & $\mathrm{~K}^{+}$ & $\mathrm{Na}^{+}$ & $\mathrm{SB}^{(2)}$ & $\mathrm{CTC}_{\mathrm{e}}{ }^{(3)}$ & $\mathrm{CTC}^{(4)}$ & $\mathrm{V}^{(5)}$ & $\mathrm{m}^{(6)}$ & $\operatorname{PST}^{(7)}$ \\
\hline $\mathrm{cm}$ & água & $\mathrm{KCl}$ & $\mathrm{CaCl}_{2}$ & $\mathrm{~g} \mathrm{~kg}^{-1}$ & $\mathrm{mg} \mathrm{kg}^{-1}$ & \multicolumn{9}{|c|}{ 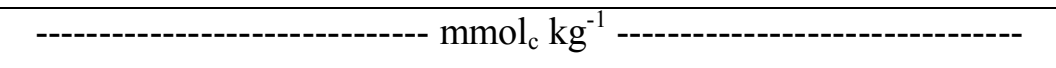 } & \multicolumn{3}{|c|}{-------- $\%$--------- } \\
\hline $0-10$ & 5,8 & 4,7 & 5,0 & 26 & 11 & 23 & 0,0 & 18,0 & 7,0 & 1,9 & 1,2 & 28,1 & 28,1 & 51,1 & 55,0 & 0,0 & 2,3 \\
\hline $10-20$ & 5,5 & 4,5 & 4,7 & 20 & 5 & 21 & 1,0 & 16,0 & 8,0 & 1,1 & 0,8 & 25,9 & 26,9 & 46,9 & 55,2 & 3,7 & 1,7 \\
\hline $20-40$ & 5,3 & 4,3 & 4,5 & 18 & 2 & 24 & 4,0 & 13,0 & 8,0 & 0,8 & 0,6 & 22,4 & 26,4 & 46,4 & 48,3 & 15,2 & 1,3 \\
\hline $40-60$ & 5,0 & 4,1 & 4,4 & 20 & 2 & 26 & 5,0 & 12,0 & 6,0 & 0,7 & 0,9 & 19,6 & 24,6 & 45,6 & 43,0 & 20,3 & 2,0 \\
\hline $60-80$ & 5,2 & 4,2 & 4,3 & 15 & 2 & 25 & 7,0 & 10,0 & 6,0 & 0,7 & 0,7 & 17,4 & 24,4 & 42,4 & 41,0 & 28,7 & 1,7 \\
\hline $80-100$ & 4,9 & 4,1 & 4,3 & 13 & 1 & 22 & 6,0 & 7,0 & 6,0 & 1,0 & 1,0 & 15,0 & 21,0 & 37,0 & 40,5 & 28,6 & 2,7 \\
\hline $\begin{array}{l}\text { (1) Matéria } \\
\text { (2) soma de } \\
\text { (3) capacida } \\
\text { (4) capacida } \\
\text { (5) saturaçã } \\
\text { (6) saturaçã } \\
\text { (7) percentu }\end{array}$ & $\begin{array}{l}\text { orgânic } \\
\text { bases }= \\
\text { de de tr } \\
\text { de de tr } \\
\text { por ba } \\
\text { por A } \\
\text { de só }\end{array}$ & $\begin{array}{l}\text { métc } \\
\mathrm{SB}= \\
\text { oca de } \\
\text { oca de } \\
\text { ses } \Rightarrow \\
\Rightarrow \mathrm{m}^{0} \\
\text { dio tro }\end{array}$ & $\begin{array}{l}\text { do Walk } \\
\text { Ca }+\mathrm{Mg} \\
\text { cátions } \\
\text { cátions } \\
\mathrm{SB} * 100 \\
0^{2}=\mathrm{Al} * 1\end{array}$ & $\begin{array}{l}\text { kley-Bla } \\
\text { g, }+\mathrm{K}+\mathrm{N} \\
\text { efetiva } \\
\text { a pH } 7= \\
/ \mathrm{CTC} ; \\
100 / \mathrm{CTC} \\
\text { PST }=\end{array}$ & $\begin{array}{l}\text { ck; } \\
\mathrm{a} ; \\
\Rightarrow \mathrm{CTCe} \\
\Rightarrow \mathrm{CTC}= \\
\text {; } \\
\mathrm{Na} * 100 / \mathrm{C}\end{array}$ & $\begin{array}{l}\mathrm{SB}+\mathrm{Al} \\
\mathrm{SB}+\mathrm{H}+\end{array}$ & & & & & & & & & & & \\
\hline
\end{tabular}


Tabela 9. Frações granulométricas e argila dispersa em água (ADA) para caracterização do solo previamente à instalação do experimento

\begin{tabular}{|c|c|c|c|c|c|c|}
\hline Camadas & Areia total & Silte & Argila & $\mathrm{ADA}^{(1)}$ & $\mathrm{GD}^{(2)}$ & Classe textural $^{(3)}$ \\
\hline $\mathrm{cm}$ & ------------------ & ------- & --------- & -------------- & $\%$ & \\
\hline $0-10$ & 762,1 & 105,3 & 132,5 & 42,9 & 32,4 & franco arenoso \\
\hline $10-20$ & 762,7 & 78,5 & 158,7 & 45,2 & 28,4 & franco arenoso \\
\hline $20-40$ & 780,1 & 59,0 & 161,0 & 50,7 & 31,5 & franco arenoso \\
\hline $40-60$ & 692,2 & 79,5 & 228,3 & 63,2 & 27,7 & franco argilo arenoso \\
\hline $60-80$ & 682,5 & 96,3 & 221,2 & 48,7 & 22 & franco argilo arenoso \\
\hline $80-100$ & 699,0 & 80,9 & 220,1 & 2,8 & 1,3 & franco argilo arenoso \\
\hline
\end{tabular}

(2) grau de dispersão de argilas $\Rightarrow \mathrm{GD}=\mathrm{ADA} * 100$ /argila total);

(3) determinadas com base no triângulo de classes texturais do Departamento de Agricultura dos Estados Unidos (USDA). 


\subsubsection{Acidez ativa (pH)}

Os valores de $\mathrm{pH}$ no mês de julho foram menores que no mês de abril, exceto para as camadas 0-10 e 40-60 cm. Isso indicou que, independentemente dos tratamentos, ocorreu acidificação do solo com o tempo de experimento (Tabela 10).

Tabela 10. Valores de $\mathrm{pH}$ do solo em solução de $\mathrm{CaCl}_{2} 0,01 \mathrm{~mol} \mathrm{~L}^{-1}$ após irrigação com água ou efluente de esgoto nos meses de abril e julho de 2003

\begin{tabular}{|c|c|c|c|c|c|c|c|}
\hline \multirow{2}{*}{ Época } & \multicolumn{7}{|c|}{ Tratamento $^{(1)}$} \\
\hline & A & E1 & E2 & E3 & E4 & Média & $C V(\%)^{(2)}$ \\
\hline & \multicolumn{7}{|c|}{ camada $0-10 \mathrm{~cm}$} \\
\hline Abril & 4,90 & 5,08 & 4,67 & 4,63 & 4,78 & $4,81 \mathrm{a}^{(3)}$ & 3,2 \\
\hline Julho & 5,15 & 5,08 & 4,70 & 4,60 & 4,60 & $4,83 \mathrm{a}$ & \\
\hline Média & $5,03 \mathrm{~A}^{(3)}$ & $5,08 \mathrm{~A}$ & $4,69 \mathrm{~B}$ & $4,61 \mathrm{~B}$ & $4,69 \mathrm{~B}$ & & \\
\hline \multirow[t]{2}{*}{$C V(\%)^{(3)}$} & 5,1 & & & & & & \\
\hline & \multicolumn{7}{|c|}{ camada $10-20 \mathrm{~cm}$} \\
\hline Abril & 4,88 & 5,03 & 4,72 & 4,70 & 4,78 & $4,82 \mathrm{a}$ & 2,3 \\
\hline Julho & 4,90 & 5,00 & 4,50 & 4,50 & 4,75 & $4,73 \mathrm{~b}$ & \\
\hline Média & 4,89B & $5,01 \mathrm{~A}$ & $4,61 \mathrm{C}$ & $4,60 \mathrm{C}$ & $4,76 \mathrm{BC}$ & & \\
\hline \multirow[t]{2}{*}{$C V(\%)^{(3)}$} & 6,6 & & & & & & \\
\hline & \multicolumn{7}{|c|}{ camada $20-40 \mathrm{~cm}$} \\
\hline Abril & 4,56 & 4,70 & 4,30 & 4,35 & 4,50 & $4,49 \mathrm{a}$ & 5,4 \\
\hline Julho & 4,63 & 4,45 & 4,13 & 4,10 & 4,18 & $4,30 \mathrm{~b}$ & \\
\hline Média & $4,60 \mathrm{~A}$ & $4,58 \mathrm{AB}$ & $4,21 \mathrm{~B}$ & $4,23 \mathrm{~B}$ & $4,34 \mathrm{AB}$ & & \\
\hline \multirow[t]{2}{*}{$C V(\%)^{(3)}$} & 5,8 & & & & & & \\
\hline & \multicolumn{7}{|c|}{ camada $40-60 \mathrm{~cm}$} \\
\hline Abril & 4,45 & 4,33 & 4,18 & 4,25 & 4,28 & $4,30 \mathrm{a}$ & 3,6 \\
\hline Julho & 4,53 & 4,28 & 4,08 & 4,10 & 4,15 & $4,23 \mathrm{a}$ & \\
\hline Média & $4,49 \mathrm{~A}$ & $4,30 \mathrm{AB}$ & $4,13 \mathrm{~B}$ & $4,18 \mathrm{~B}$ & $4,21 \mathrm{~B}$ & & \\
\hline \multirow[t]{2}{*}{$C V(\%)^{(3)}$} & 5,9 & & & & & & \\
\hline & \multicolumn{7}{|c|}{ camada $60-80 \mathrm{~cm}$} \\
\hline Abril & 4,58 & 4,33 & 4,23 & 4,23 & 4,23 & $4,32 \mathrm{a}$ & 1,8 \\
\hline Julho & 4,38 & 4,20 & 4,08 & 4,23 & 4,15 & $4,21 \mathrm{~b}$ & \\
\hline Média & $4,48 \mathrm{~A}$ & $4,26 \mathrm{~B}$ & $4,15 \mathrm{~B}$ & $4,23 \mathrm{~B}$ & $4,19 \mathrm{~B}$ & & \\
\hline \multirow[t]{2}{*}{$C V(\%)^{(3)}$} & 6,0 & & & & & & \\
\hline & \multicolumn{7}{|c|}{ camada $80-100 \mathrm{~cm}$} \\
\hline Abril & 4,45 & 4,35 & 4,23 & 4,25 & 4,30 & $4,32 \mathrm{a}$ & 1,4 \\
\hline Julho & 4,35 & 4,25 & 4,13 & 4,15 & 4,13 & $4,20 \mathrm{~b}$ & \\
\hline $\begin{array}{c}\text { Média } \\
C V(\%)^{(3)}\end{array}$ & $\begin{array}{r}4,40 \mathrm{~A} \\
4,6\end{array}$ & $4,30 \mathrm{~B}$ & $4,17 \mathrm{C}$ & $4,20 \mathrm{C}$ & $4,21 \mathrm{BC}$ & & \\
\hline $\begin{array}{l}\text { (1) A (água }+ \\
\text { de N), E4 } \\
\text { (2) coeficient } \\
\text { (3) coeficient } \\
\text { (4) letras igua } \\
\text { teste de T }\end{array}$ & $\begin{array}{l}0 \% \text { de } \mathrm{N}) \\
\text { fluente }+10 \\
\text { le variação } \\
\text { e variação } \\
\text { maiúsculas }\end{array}$ & $\begin{array}{l}1 \text { (efluent } \\
\% \text { de } \mathrm{N} \text { ) } \\
\text { ara os trat } \\
\text { ara as épo } \\
\text { las linhas }\end{array}$ & $\begin{array}{l}0 \% \text { de } \mathrm{N} \\
\text { entos }(\mathrm{A} \text {, } \\
\text { (abril e j } \\
\text { ninúscula }\end{array}$ & $\begin{array}{l}\text { E2 (eflue } \\
\text { 1, E2, E3 } \\
\text { ho); } \\
\text { as colun }\end{array}$ & $\begin{array}{l}\text { e+33\% de } \\
\text { não difere }\end{array}$ & ); E3 (efl & nte $+66 \%$ \\
\hline
\end{tabular}


Os efeitos dos tratamentos sobre o $\mathrm{pH}$ foram observados para todas as camadas somente para médias entre épocas. Maiores valores de $\mathrm{pH}$ foram observados nos tratamentos A (camadas 0-10 e 60-100 cm) e no tratamento E1 $(0-20 \mathrm{~cm}) . \mathrm{Na}$ camada 0-10 cm os tratamentos E2, E3 e E4 diferiram de A e de E1 e na camada 10-20 $\mathrm{cm}$ o tratamento E1 diferiu dos demais tratamentos. Na camada $20-40 \mathrm{~cm}$ os tratamentos E2 e E3 diferiram de A enquanto E1 não diferiu dos demais tratamentos com efluente. Na camada 40-60 cm E2, E3 e E4 diferiram de A, porém, não diferiram de E1. Na camada $60-80 \mathrm{~cm}$ os tratamentos de irrigação com efluente foram iguais entre si, mas diferiram de A. Na camada $80-100 \mathrm{~cm}$ todos os tratamentos de irrigação com efluente diferiram de A enquanto os tratamentos E2 e E3 diferiram de E1.

Dentre os tratamentos com efluente, os maiores valores em superfície foram obtidos para o tratamento E1, provavelmente devido à ausência de fertilização nitrogenada (Tabela 3). A fertilização nitrogenada amoniacal, como a que foi realizada no experimento, tem efeito sobre a acidificação do solo (Brady \& Weil, 1999) e este fato pode explicar ainda os menores valores de $\mathrm{pH}$ observados para todas as camadas de solo para os tratamentos E2, E3 e E4. Do mesmo modo, Hayes et al., (1990) e Vazquez-Montiel et al. (1996) atribuíram a redução de pH do solo irrigado com água ou efluente à nitrificação de fontes de $\mathrm{N}$ do solo.

Os maiores valores de $\mathrm{pH}$ obtidos no solo sob o tratamento A, em relação ao tratamento $\mathrm{E} 4$, podem ser atribuídos aos maiores valores de $\mathrm{pH}$ apresentados pela água durante o período experimental e à provável acidificação do solo devido a nitrificação do nitrogênio adicionado ao solo via irrigação com efluente (tratamento E4). Entre os tratamentos A e E4, os valores de $\mathrm{pH}$ foram superiores para A nas camadas 0 $10,40-60,60-80$ e 80-100 cm em 0,34, 0,28, 0,29, e 0.21 unidades, respectivamente. Do mesmo modo, Smith et al. (1996) atribuem as mudanças de $\mathrm{pH}$ do solo ao $\mathrm{pH}$ alcalino da fonte de água utilizada para irrigação. Porém, Hayes et al., (1990) não relacionaram as mudanças de $\mathrm{pH}$ do solo aos valores de $\mathrm{pH}$ da água e do efluente, no entanto, naquele estudo, o pH da água foi superior ao do efluente em apenas 0,3 unidades, enquanto que o pH da água de Lins foi superior, em média, 2,45 unidades (Tabela 4). 
Falkiner \& Smith (1997) observaram aumento do pH do solo em cerca de 0,7 unidades para tratamento com efluente e 0,3 unidades para tratamento com água em sistema de cultivo florestal após 4 anos de irrigação. Porém, neste caso o pH do efluente utilizado foi superior ao da água em 0,40 unidades, fato que resultou em maior aumento do pH do solo sob irrigação com efluente num longo período de irrigação. Aumento do pH em solos de campo (4 anos de irrigação) e floresta (17 anos de irrigação), sob irrigação com efluente, também foi observado por Smith et al. (1996).

Apesar das diferenças de $\mathrm{pH}$ do solo obtidas não terem sido elevadas entre os tratamentos (diferenças inferiores a 1 unidade), diferenças dessa ordem têm sido consideradas na literatura como sendo significativas, refletindo o efeito da irrigação com água ou efluente sobre os valores de $\mathrm{pH}$ do solo após vários anos de irrigação. Em sistemas de cultivos agrícolas e florestais alterações de $\mathrm{pH}$ dessa ordem não influenciam a produção, tendo em vista que práticas de correção do $\mathrm{pH}$ do solo são adotadas para assegurar maiores rendimentos.

\subsubsection{Acidez potencial $(\mathrm{H}+\mathrm{Al})$}

Os teores de $\mathrm{H}+\mathrm{Al}$ (Tabela 11) aumentaram em toda a área experimental com o tempo, independentemente dos tratamentos empregados, apenas nas camadas 1020 e 80-100 cm. Verificou-se interação entre tratamentos e épocas nas camadas 0-10 e 40-60 cm, sendo que, na camada $0-10 \mathrm{~cm}$ houve aumento do teor de $\mathrm{H}+\mathrm{Al}$ com o tempo nos tratamentos E1 e E3, enquanto que na camada $40-60 \mathrm{~cm}$, o aumento foi observado apenas para o tratamento E3.

No mês de abril, não foram observadas diferenças entre os tratamentos na camada 0-10 cm, no entanto, no mês de julho, para esta mesma camada, o tratamento E1 conferiu o maior valor diferindo de A e de E2. No mês de abril, camada 40-60 cm, os tratamentos com efluente não diferiram de $\mathrm{A}$, do mesmo modo que $\mathrm{E} 1$ não diferiu dos demais tratamentos com efluente. Em julho, para a mesma camada, não foram observadas diferenças entre os tratamentos de irrigação. Na camada $10-20 \mathrm{~cm}$ foram observados efeitos de tratamento sobre médias de teores de $\mathrm{H}+\mathrm{Al}$ entre épocas, onde os 
tratamentos E1 e E2 conferiram médias maiores diferindo de A, enquanto nenhuma diferença foi observada entre E1 e os demais tratamentos com efluente.

Tabela 11. Teores de $\mathrm{H}+\mathrm{Al}\left(\mathrm{mmol}_{\mathrm{c}} \mathrm{L}^{-1}\right)$ no solo após irrigação com água ou efluente de esgoto nos meses de abril e julho de 2003

\begin{tabular}{|c|c|c|c|c|c|c|c|}
\hline \multirow{2}{*}{ Época } & \multicolumn{7}{|c|}{ Tratamento $^{(1)}$} \\
\hline & A & E1 & E2 & E3 & E4 & Média & $C V(\%)^{(2)}$ \\
\hline & \multicolumn{7}{|c|}{ camada $0-10 \mathrm{~cm}$} \\
\hline Abril & $15,00 \mathrm{aA}^{(4)}$ & $14,25 \mathrm{bA}$ & $17,25 \mathrm{aA}$ & $16,50 \mathrm{bA}$ & $15,25 \mathrm{aA}$ & 15,65 & 13,1 \\
\hline Julho & $17,50 \mathrm{aB}$ & $22,50 \mathrm{aA}$ & $17,00 \mathrm{aB}$ & $20,50 \mathrm{aAB}$ & $18,00 \mathrm{aAB}$ & 19,10 & \\
\hline Média & 16,25 & 18,38 & 17,13 & 18,50 & 16,63 & & \\
\hline \multirow[t]{2}{*}{$C V(\%)^{(3)}$} & 8,5 & & & & & & \\
\hline & & \multicolumn{5}{|c|}{ camada $10-20 \mathrm{~cm}$} & - \\
\hline Abril & 14,75 & 15,25 & 16,75 & 16,75 & 16,00 & $15,90 b^{(4)}$ & 11,2 \\
\hline Julho & 15,25 & 21,50 & 20,75 & 19,00 & 18,00 & $18,90 \mathrm{a}$ & \\
\hline Média & $15,00 \mathrm{~B}$ & $18,38 \mathrm{~A}$ & $18,75 \mathrm{~A}$ & $17,88 \mathrm{AB}$ & $17,00 \mathrm{AB}$ & & \\
\hline \multirow[t]{2}{*}{$C V(\%)^{(3)}$} & 8,0 & & & & & & \\
\hline & \multicolumn{7}{|c|}{ camada $20-40 \mathrm{~cm}$} \\
\hline Abril & 41,50 & 51,25 & 49,50 & 39,25 & 56,00 & $47,50 \mathrm{a}$ & 57,5 \\
\hline Julho & 29,50 & 67,00 & 29,50 & 42,00 & 54,50 & $44,50 \mathrm{a}$ & \\
\hline Média & $35,50 \mathrm{~A}$ & $59,13 \mathrm{~A}$ & $39,50 \mathrm{~A}$ & $40,63 \mathrm{~A}$ & $55,25 \mathrm{~A}$ & & \\
\hline \multirow[t]{2}{*}{$C V(\%)^{(3)}$} & 51,6 & & & & & & \\
\hline & \multicolumn{7}{|c|}{ camada $40-60 \mathrm{~cm}$} \\
\hline Abril & $0,40 \mathrm{aAB}$ & $0,60 \mathrm{aAB}$ & $0,40 \mathrm{aAB}$ & $0,10 \mathrm{bB}$ & $0,68 \mathrm{aA}$ & 0,44 & 57,0 \\
\hline Julho & $0,45 \mathrm{aA}$ & $0,45 \mathrm{aA}$ & $0,35 \mathrm{aA}$ & $0,68 \mathrm{aA}$ & $0,40 \mathrm{aA}$ & 0,47 & \\
\hline Média & 0,43 & 0,53 & 0,38 & 0,39 & 0,54 & & \\
\hline \multirow[t]{2}{*}{$C V(\%)^{(3)}$} & 44,8 & & & & & & \\
\hline & \multicolumn{7}{|c|}{ camada $60-80 \mathrm{~cm}$} \\
\hline Abril & 8,20 & 4,43 & 3,18 & 3,55 & 4,75 & $4,82 \mathrm{a}$ & 68,4 \\
\hline Julho & 3,00 & 3,98 & 4,65 & 5,13 & 4,35 & $4,22 \mathrm{a}$ & \\
\hline Média & $5,59 \mathrm{~A}$ & $4,20 \mathrm{~A}$ & $3,91 \mathrm{~A}$ & $4,34 \mathrm{~A}$ & $4,55 \mathrm{~A}$ & & \\
\hline \multirow[t]{2}{*}{$C V(\%)^{(3)}$} & 35,7 & & & & & & \\
\hline & \multicolumn{7}{|c|}{ camada $80-100 \mathrm{~cm}$} \\
\hline Abril & 17,50 & 18,50 & 18,75 & 19,25 & 18,25 & $18,45 \mathrm{~b}$ & 11,2 \\
\hline Julho & 22,00 & 17,50 & 22,00 & 22,00 & 22,75 & $21,25 \mathrm{a}$ & \\
\hline Média & $19,75 \mathrm{~A}$ & $18,00 \mathrm{~A}$ & $20,38 \mathrm{~A}$ & $20,63 \mathrm{~A}$ & $20,50 \mathrm{~A}$ & & \\
\hline$C V(\%)^{(3)}$ & 8,8 & & & & & & \\
\hline \multicolumn{8}{|c|}{$\begin{array}{l}\text { (1) A (água }+100 \% \text { de } \mathrm{N}) \text {; E1 (efluente }+0 \% \text { de } \mathrm{N}) \text {, E2 (efluente }+33 \% \text { de N); E3 (efluente+ } 66 \% \\
\text { de } \mathrm{N}) \text {, E4 (efluente+ } 100 \% \text { de } \mathrm{N}) \\
\text { (2) } \\
\text { coeficiente de variação para os tratamentos }(\mathrm{A}, \mathrm{E} 1, \mathrm{E} 2, \mathrm{E} 3, \mathrm{E} 4) ; \\
\text { (3) coeficiente de variação para as épocas (abril e julho); } \\
\text { (4) letras iguais maiúsculas nas linhas e minúsculas nas colunas não diferem estatisticamente pelo } \\
\text { teste de Tukey }(\mathrm{P}<0,05) \text {. }\end{array}$} \\
\hline
\end{tabular}




\subsubsection{Teores de sódio, potássio, cálcio+magnésio e alumínio trocáveis e saturação de bases}

\section{Sódio}

$\mathrm{O}$ teor de $\mathrm{Na}$ trocável aumentou com o tempo em toda a área experimental, independentemente dos tratamentos (Tabela 12). $\mathrm{O}$ aumento foi observado, exceto para a camada $80-100 \mathrm{~cm}$, e foi coerente com o fato de altas quantidades de $\mathrm{Na}$ estarem presentes tanto na água como no efluente (Tabela 4).

Os efeitos de tratamentos sobre os teores de $\mathrm{Na}$ foram evidenciados apenas nas camadas de 0-10 e 20-40 cm, para médias de épocas (Tabela 12). No entanto, a camada de $0-10 \mathrm{~cm}$ foi a que melhor refletiu as diferenças entre tratamentos, sendo que, para as demais camadas, diferenças entre os tratamentos provavelmente seriam evidentes e melhor explicadas após um maior período de irrigação.

A maior média foi obtida para o tratamento A quando comparado ao tratamento E1 e E3 (camada 0-10 cm). Apesar de não ter sido obtida diferença significativa de teor de $\mathrm{Na}$ entre $\mathrm{A}$ e E2, de modo geral, o tratamento A parace estar resultando num maior teor de $\mathrm{Na}$ no solo. Esse aumento é coerente com a maior adição de $\mathrm{Na}$ decorrente do maior volume de irrigação no tratamento A (Tabela 6).

Não foram observadas diferenças significativas de $\mathrm{Na}$ no solo entre os tratamentos A e E4 que receberam volumes praticamente iguais de água e efluente, respectivamente, durante o período experimental. Apesar do efluente ter apresentado, em média, $0,75 \mathrm{mmol}_{\mathrm{c}} \mathrm{L}^{-1}$ de $\mathrm{Na}$ a mais em relação a água durante o período estudado (Tabela 4), maiores teores desse elemento têm sido observadas em solos irrigados com efluente por longos períodos de tempo e quando as concentração de $\mathrm{Na}$ entre a água e o efluente são mais pronunciadas (por exemplo, 1,35, 2,06 e 3,2 $\mathrm{mmol}_{\mathrm{c}} \mathrm{L}^{-1}$ de $\mathrm{Na}$ a mais no efluente), (Hayes et al., 1990; Johns \& McConchie, 1994; Falkiner \& Smith, 1997;). 
Tabela 12. Teor de Na trocável $\left(\mathrm{mmol}_{\mathrm{c}} \mathrm{L}^{-1}\right)$ no solo após irrigação com água ou efluente de esgoto nos meses de abril e julho de 2003

\begin{tabular}{|c|c|c|c|c|c|c|c|}
\hline \multirow{2}{*}{ Época } & \multicolumn{7}{|c|}{ Tratamento $^{(1)}$} \\
\hline & A & E1 & E2 & E3 & E4 & Média & $C V(\%)^{(2)}$ \\
\hline & \multicolumn{7}{|c|}{ camada $0-10 \mathrm{~cm}$} \\
\hline Abril & 1,36 & 0,84 & 0,84 & 0,81 & 0,80 & $0,93 b^{(3)}$ & 14,4 \\
\hline Julho & 2,90 & 2,60 & 2,88 & 2,62 & 2,71 & $2,74 \mathrm{a}$ & \\
\hline Média & $2,13 \mathrm{~A}^{(3)}$ & $1,72 \mathrm{~B}$ & $1,86 \mathrm{AB}$ & $1,71 \mathrm{~B}$ & $1,75 \mathrm{AB}$ & & \\
\hline \multirow[t]{2}{*}{$C V(\%)^{(3)}$} & 11,1 & & & & & & \\
\hline & \multicolumn{7}{|c|}{ camada $10-20 \mathrm{~cm}$} \\
\hline Abril & 0,75 & 0,53 & 0,62 & 0,57 & 0,47 & $0,59 \mathrm{~b}$ & 25,6 \\
\hline Julho & 1,63 & 1,45 & 1,67 & 1,51 & 1,42 & $1,54 \mathrm{a}$ & \\
\hline Média & $1,19 \mathrm{~A}$ & $0,99 \mathrm{~A}$ & $1,15 \mathrm{~A}$ & $1,04 \mathrm{~A}$ & $0,94 \mathrm{~A}$ & & \\
\hline \multirow[t]{2}{*}{$C V(\%)^{(3)}$} & 9,6 & & & & & & \\
\hline & \multicolumn{7}{|c|}{ camada $20-40 \mathrm{~cm}$} \\
\hline Abril & 0,44 & 0,25 & 0,52 & 0,27 & 0,24 & $0,34 \mathrm{~b}$ & 28,3 \\
\hline Julho & 0,50 & 0,59 & 0,55 & 0,49 & 0,42 & $0,51 \mathrm{a}$ & \\
\hline Média & $0,47 \mathrm{AB}$ & $0,42 \mathrm{AB}$ & $0,53 \mathrm{~A}$ & $0,38 \mathrm{AB}$ & $0,33 \mathrm{~B}$ & & \\
\hline \multirow[t]{2}{*}{$C V(\%)^{(3)}$} & 28,7 & & & & & & \\
\hline & \multicolumn{7}{|c|}{ camada $40-60 \mathrm{~cm}$} \\
\hline Abril & 0,23 & 0,15 & 0,15 & 0,14 & 0,15 & $0,17 \mathrm{~b}$ & 38,9 \\
\hline Julho & 0,26 & 0,34 & 0,28 & 0,24 & 0,26 & $0,28 \mathrm{a}$ & \\
\hline Média & $0,25 \mathrm{~A}$ & $0,25 \mathrm{~A}$ & $0,22 \mathrm{~A}$ & $0,19 \mathrm{~A}$ & $0,20 \mathrm{~A}$ & & \\
\hline \multirow[t]{2}{*}{$C V(\%)^{(3)}$} & 17,2 & & & & & & \\
\hline & \multicolumn{7}{|c|}{ camada $60-80 \mathrm{~cm}$} \\
\hline Abril & 0,19 & 0,14 & 0,23 & 0,13 & 0,13 & $0,16 b$ & 36,4 \\
\hline Julho & 0,23 & 0,27 & 0,25 & 0,19 & 0,20 & $0,23 \mathrm{a}$ & \\
\hline Média & $0,21 \mathrm{~A}$ & $0,20 \mathrm{~A}$ & $0,24 \mathrm{~A}$ & $0,16 \mathrm{~A}$ & $0,16 \mathrm{~A}$ & & \\
\hline \multirow[t]{2}{*}{$C V(\%)^{(3)}$} & 21,9 & & & & & & \\
\hline & \multicolumn{7}{|c|}{ camada $80-100 \mathrm{~cm}$} \\
\hline Abril & 0,17 & 0,13 & 0,26 & 0,14 & 0,13 & $0,17 \mathrm{a}$ & 32,7 \\
\hline Julho & 0,16 & 0,20 & 0,22 & 0,16 & 0,19 & $0,18 \mathrm{a}$ & \\
\hline Média & $0,17 \mathrm{~A}$ & $0,16 \mathrm{~A}$ & $0,24 \mathrm{~A}$ & $0,15 \mathrm{~A}$ & $0,16 \mathrm{~A}$ & & \\
\hline$C V(\%)^{(3)}$ & 20,6 & & & & & & \\
\hline $\begin{array}{l}\text { (1) A (água +1 } \\
\text { de N), E4 } \\
\text { (2) coeficiente } \\
\text { (3) coeficiente } \\
\text { (4) letras iguai } \\
\text { teste de Tu }\end{array}$ & $\begin{array}{l}0 \% \text { de } \mathrm{N}) \\
\text { fluente }+10( \\
\text { le variação } \\
\text { e variação } \\
\text { maiúsculas }\end{array}$ & $\begin{array}{l}1 \text { (efluente } \\
\% \text { de } \mathrm{N} \text { ) } \\
\text { ara os trata } \\
\text { ara as époc } \\
\text { tas linhas e }\end{array}$ & $\begin{array}{l}+0 \% \text { de } \mathrm{N} \text { ) } \\
\text { nentos (A, } \\
\text { s (abril e ju } \\
\text { minúsculas }\end{array}$ & $\begin{array}{l}\text { E2 (eflue } \\
\text { 1, E2, E3 } \\
\text { ho); } \\
\text { has coluna }\end{array}$ & $\begin{array}{l}\text { +33\% de } \\
\text { 1);o difere }\end{array}$ & N); E3 (efl & ente $+66 \%$ \\
\hline
\end{tabular}

Embora devida importância deva ser dada à presença de $\mathrm{Na}$ no efluente $\mathrm{e}$ ao consequente aporte desse elemento no solo, os riscos de alterações da estrutura dos solos, propriamente ditos, são atribuídos às fontes de água para irrigação (água ou 
efluente) de acordo com os valores de RAS e CE que apresentam (Ayers \& Westcot, 1985). A salinidade do solo, quando aumentada, reduz o potencial do sódio para dispersar partículas do solo (Hayes et al., 1990), portanto, maior salinidade da água ou do efluente é desejável quando os valores de RAS são elevados. No presente estudo, o efluente apresentou os maiores valores de CE e os menores valores de RAS que a água durante todos os meses de irrigação (Tabela 4).

\section{Potássio}

Independentemente dos tratamentos, os teores de $\mathrm{K}$ trocável na área experimental aumentaram com o tempo na camada $0-10 \mathrm{~cm}$ e diminuíram nas camadas 10-20 e 20-40 cm do solo (Tabela 13).

O aumento na camada $0-10 \mathrm{~cm}$ pode ser atribuído à fertilização mineral potássica que foi realizada em todas as parcelas durante o período de irrigação. No entanto, apesar de não terem sido observados efeitos de tempo sobre cada tratamento, é importante considerar que a irrigação com efluente (tratamentos E1, E2, E3 e E4) pode ter contribuído para o aumento do teor de $\mathrm{K}$ em toda a área com o tempo como foi observado em experimento conduzido por Hayes et al. (1990). A irrigação com efluente não satisfaz a necessidade das culturas por $\mathrm{K}$, porém pode promover o aumento dos teores no solo (Feigin et al. 1991).

Efeitos de tratamento sobre o teor de $\mathrm{K}$ no solo foram observados nas camadas 0-10, 10-20 e 80-100 cm. Porém, do mesmo modo que para o $\mathrm{Na}$, os efeitos dos tratamentos foram melhor entendidos em superfície. Observa-se na camada 0-10 cm que o tratamento $\mathrm{E} 2$ conferiu maior teor de $\mathrm{K}$ em relação ao tratamento $\mathrm{A}$ e, dentre tratamentos com efluente, E1 conferiu maior teor em relação a E3. Na camada 10-20 cm os tratamentos com efluente não diferiram de $\mathrm{A}$, porém, o teor em E1 foi maior que em E3. Na camada 80-100 cm, apenas E1 diferiu de A. 
Tabela 13. Teor de $\mathrm{K}$ trocável $\left(\mathrm{mmol}_{\mathrm{c}} \mathrm{L}^{-1}\right)$ no solo após irrigação com água ou efluente de esgoto nos meses de abril e julho de 2003

\begin{tabular}{|c|c|c|c|c|c|c|c|}
\hline \multirow{2}{*}{ Época } & \multicolumn{7}{|c|}{ Tratamento $^{(1)}$} \\
\hline & A & E1 & E2 & E3 & E4 & Média & $C V(\%)^{(2)}$ \\
\hline & \multicolumn{7}{|c|}{ camada $0-10 \mathrm{~cm}$} \\
\hline Abril & 2,07 & 2,02 & 2,54 & 1,66 & 1,78 & $2,02 \mathrm{~b}^{(3)}$ & 11,1 \\
\hline Julho & 2,40 & 2,66 & 2,74 & 2,17 & 2,38 & $2,47 \mathrm{a}$ & \\
\hline Média & $2,23 \mathrm{BC}^{(3)}$ & $2,34 \mathrm{AB}$ & $2,64 \mathrm{~A}$ & $1,91 \mathrm{C}$ & $2,08 \mathrm{BC}$ & & \\
\hline \multirow[t]{2}{*}{$C V(\%)^{(3)}$} & 11,1 & & & & & & \\
\hline & \multicolumn{7}{|c|}{ camada $10-20 \mathrm{~cm}$} \\
\hline Abril & 1,23 & 1,21 & 1,24 & 0,97 & 1,17 & $1,16 \mathrm{a}$ & 15,7 \\
\hline Julho & 0,82 & 1,00 & 0,88 & 0,71 & 0,71 & $0,82 \mathrm{~b}$ & \\
\hline Média & $1,03 \mathrm{AB}$ & $1,10 \mathrm{~A}$ & $1,06 \mathrm{AB}$ & $0,84 \mathrm{~B}$ & $0,94 \mathrm{AB}$ & & \\
\hline \multirow{2}{*}{$C V(\%)^{(3)}$} & 14,8 & & & & & & \\
\hline & \multicolumn{7}{|c|}{ camada $20-40 \mathrm{~cm}$} \\
\hline Abril & 0,70 & 0,69 & 0,77 & 0,62 & 0,76 & $0,71 \mathrm{a}$ & 13,8 \\
\hline Julho & 0,50 & 0,62 & 0,64 & 0,54 & 0,54 & $0,57 \mathrm{~b}$ & \\
\hline Média & $0,60 \mathrm{~A}$ & $0,65 \mathrm{~A}$ & $0,71 \mathrm{~A}$ & $0,58 \mathrm{~A}$ & $0,65 \mathrm{~A}$ & & \\
\hline \multirow[t]{2}{*}{$C V(\%)^{(3)}$} & 15,1 & & & & & & \\
\hline & \multicolumn{7}{|c|}{ camada $40-60 \mathrm{~cm}$} \\
\hline Abril & 0,53 & 0,52 & 0,57 & 0,50 & 0,53 & $0,53 \mathrm{a}$ & 11,0 \\
\hline Julho & 0,54 & 0,52 & 0,52 & 0,46 & 0,49 & $0,50 \mathrm{a}$ & \\
\hline Média & $0,53 \mathrm{~A}$ & $0,52 \mathrm{~A}$ & $0,54 \mathrm{~A}$ & $0,48 \mathrm{~A}$ & $0,51 \mathrm{~A}$ & & \\
\hline \multirow[t]{2}{*}{$C V(\%)^{(3)}$} & 11,9 & & & & & & \\
\hline & \multicolumn{7}{|c|}{ camada $60-80 \mathrm{~cm}$} \\
\hline Abril & 0,47 & 0,47 & 0,51 & 0,46 & 0,43 & $0,47 \mathrm{a}$ & 17,3 \\
\hline Julho & 0,46 & 04,7 & 0,55 & 0,48 & 0,48 & $0,49 \mathrm{a}$ & \\
\hline Média & $0,47 \mathrm{~A}$ & $0,47 \mathrm{~A}$ & $0,53 \mathrm{~A}$ & $0,47 \mathrm{~A}$ & $0,46 \mathrm{~A}$ & & \\
\hline \multirow[t]{2}{*}{$C V(\%)^{(3)}$} & 16,7 & & & & & & \\
\hline & \multicolumn{7}{|c|}{ camada $80-100 \mathrm{~cm}$} \\
\hline Abril & 0,64 & 0,46 & 0,52 & 0,54 & 0,51 & $0,53 \mathrm{a}$ & 22,5 \\
\hline Julho & 0,74 & 0,44 & 0,69 & 0,52 & 0,58 & $0,60 \mathrm{a}$ & \\
\hline Média & $0,69 \mathrm{~A}$ & $0,45 \mathrm{~B}$ & $0,60 \mathrm{AB}$ & $0,53 \mathrm{AB}$ & $0,55 \mathrm{AB}$ & & \\
\hline$C V(\%)^{(3)}$ & 23,8 & & & & & & \\
\hline $\begin{array}{l}\text { (1) A (água +1 } \\
\text { de N), E4 } \\
\text { (2) coeficiente } \\
\text { (3) coeficiente } \\
\text { (4) letras iguai } \\
\text { teste de Tu }\end{array}$ & $\begin{array}{l}0 \% \text { de } \mathrm{N}) ; \mathrm{E} \\
\text { fluente+100 } \\
\text { de variação } \mathrm{p} \\
\text { le variação p } \\
\text { maiúsculas } n\end{array}$ & $\begin{array}{l}1 \text { (efluent } \\
\% \text { de } \mathrm{N} \text { ) } \\
\text { ara os trata } \\
\text { ara as époc } \\
\text { tas linhas }\end{array}$ & $\begin{array}{l}+0 \% \text { de } \mathrm{N} \text { ) } \\
\text { nentos (A, } \\
\text { s (abril e ju } \\
\text { minúsculas }\end{array}$ & $\begin{array}{l}\text { E2 (eflue } \\
\text { 1, E2, E3 } \\
\text { 1o); } \\
\text { as coluna }\end{array}$ & $\begin{array}{l}\text { +33\% de } \\
\text { hão difere }\end{array}$ & N); E3 (eflu & ente $+66 \%$ \\
\hline
\end{tabular}

Até os $20 \mathrm{~cm}$, observa-se a tendência de haver maiores teores de $\mathrm{K}$ sob os tratamentos com os menores volumes de irrigação adicionados. Na camada 0-10 cm, essa tendência de aumento ocorreu para os tratamentos E1 e E2, enquanto que na camada $10-20 \mathrm{~cm}$, a tendência foi observada para o tratamento E1. Portanto, acredita-se 
que os menores volumes adicionados resultaram na menor remoção de $\mathrm{K}$ por lixiviação e que ainda uma menor absorção desse cátion deva ter ocorrido devido ao menor acúmulo de massa seca do capim (Tabela 26).

\section{Cálcio+Magnésio}

Os teores de $\mathrm{Ca}+\mathrm{Mg}$ trocáveis diminuíram com o tempo na área experimental nas camadas 20-40 e 80-100 cm do solo, independentemente dos tratamentos empregados (Tabela 14). Acredita-se que esta redução possa estar relacionada ao aumento do teor de $\mathrm{Na}$ (Tabela 12). Situação semelhante foi observada por Hayes et al. (1990), onde os teores de $\mathrm{Ca}+\mathrm{Mg}$ nos solos irrigados com efluente ou com água foram reduzidos devido ao aumento dos teores de $\mathrm{Na}$ que deslocaram os cátions $\mathrm{Ca}$ e $\mathrm{Mg}$ do complexo de troca.

Os efeitos de tratamento foram observados para médias de teores entre épocas em todas as camadas estudadas (Tabela 14). Na camada $0-10 \mathrm{~cm}$, o tratamento A conferiu o maior teor diferindo de E3, enquanto E1 conferiu maior teor em relação a E2, E3 e E4. Na camada 10-20 cm, os tratamentos com efluente não diferiram de A, porém o maior teor foi observado para E1 em relação a E2 e E3. Na camada 20-40 cm, os tratamentos A e E1 conferiram maiores teores diferindo de E2 e E3, enquanto que na camada 40-60 $\mathrm{cm}$ os tratamentos A e E1 apresentaram maiores teores que E2. Na camada 60-80 cm, os tratamentos com efluente não diferiram de $\mathrm{A}$ e apenas $\mathrm{E} 1$ apresentou maior teor que E2. Na camada 80-100 cm, os tratamentos A e E1 apresentaram teores maiores que E2.

Nota-se uma maior tendência dos tratamentos A e E1 apresentarem maiores teores de $\mathrm{Ca}+\mathrm{Mg}$ trocáveis no solo. Considerando os efeitos do $\mathrm{Na}$ sobre os teores de $\mathrm{Ca}+\mathrm{Mg}$, os maiores teores são esperados para o tratamento $\mathrm{E} 1$ devido à menor adição de Na nesse tratamento decorrente ao menor volume de irrigação (Tabela 7). 
Tabela 14. Teor de $\mathrm{Ca}+\mathrm{Mg}$ trocáveis $\left(\mathrm{mmol}_{\mathrm{c}} \mathrm{L}^{-1}\right)$ no solo após irrigação com água ou efluente de esgoto nos meses de abril e julho de 2003

\begin{tabular}{|c|c|c|c|c|c|c|c|}
\hline \multirow{2}{*}{ Época } & \multicolumn{7}{|c|}{ Tratamento $^{(I)}$} \\
\hline & A & E1 & $\mathrm{E} 2$ & E3 & E4 & Média & $C V(\%)^{(2)}$ \\
\hline & \multicolumn{7}{|c|}{ camada $0-10 \mathrm{~cm}$} \\
\hline Abril & 17,0 & 19,9 & 15,9 & 13,8 & 16,4 & $16,6 \mathrm{a}$ & 9,2 \\
\hline Julho & 17,4 & 19,0 & 15,8 & 13,0 & 16,9 & $16,4 \mathrm{a}$ & \\
\hline Média & $17,2 \mathrm{AB}$ & $19,4 \mathrm{~A}$ & $15,8 \mathrm{~B}$ & $13,4 \mathrm{C}$ & $16,6 \mathrm{~B}$ & & \\
\hline \multirow{2}{*}{$C V(\%)^{(3)}$} & 11,4 & & & & & & \\
\hline & \multicolumn{7}{|c|}{ camada 10-20 cm } \\
\hline Abril & 16,9 & 19,9 & 15,8 & 15,2 & 16,8 & $16,9 \mathrm{a}$ & 12,3 \\
\hline Julho & 17,8 & 19,6 & 15,4 & 14,6 & 16,7 & $16,8 \mathrm{a}$ & \\
\hline Média & $17,4 \mathrm{AB}$ & $19,7 \mathrm{~A}$ & $15,6 \mathrm{~B}$ & $14,9 \mathrm{~B}$ & $16,7 \mathrm{AB}$ & & \\
\hline \multirow[t]{2}{*}{$C V(\%)^{(3)}$} & 11,4 & & & & & & \\
\hline & \multicolumn{7}{|c|}{ camada $20-40 \mathrm{~cm}$} \\
\hline Abril & 16,0 & 16,7 & 11,9 & 12,4 & 14,9 & $14,4 \mathrm{a}$ & 15,0 \\
\hline Julho & 13,3 & 15,0 & 10,1 & 10,2 & 12,2 & $12,2 b$ & \\
\hline Média & $14,7 \mathrm{~A}$ & $15,8 \mathrm{~A}$ & $11,0 \mathrm{~B}$ & $11,3 \mathrm{~B}$ & $13,5 \mathrm{AB}$ & & \\
\hline \multirow[t]{2}{*}{$C V(\%)^{(3)}$} & 13,3 & & & & & & \\
\hline & \multicolumn{7}{|c|}{ camada $40-60 \mathrm{~cm}$} \\
\hline Abril & 15,1 & 12,1 & 9,7 & 10,3 & 11,7 & $11,8 \mathrm{a}$ & 16,9 \\
\hline Julho & 10,5 & 12,6 & 8,6 & 10,1 & 10,7 & $10,5 \mathrm{a}$ & \\
\hline Média & $12,8 \mathrm{~A}$ & $12,4 \mathrm{~A}$ & $9,2 \mathrm{~B}$ & $10,2 \mathrm{AB}$ & $11,2 \mathrm{AB}$ & & \\
\hline \multirow[t]{2}{*}{$C V(\%)^{(3)}$} & 18,4 & & & & & & \\
\hline & \multicolumn{7}{|c|}{ camada $60-80 \mathrm{~cm}$} \\
\hline Abril & 12,8 & 12,1 & 8,6 & 9,6 & 9,7 & $10,5 \mathrm{a}$ & 20,2 \\
\hline Julho & 9,4 & 10,7 & 7,7 & 8,8 & 9,8 & $9,3 \mathrm{a}$ & \\
\hline Média & $11,0 \mathrm{AB}$ & $11,4 \mathrm{~A}$ & $8,1 \mathrm{~B}$ & $9,2 \mathrm{AB}$ & $9,7 \mathrm{AB}$ & & \\
\hline \multirow[t]{2}{*}{$C V(\%)^{(3)}$} & 23,8 & & & & & & \\
\hline & \multicolumn{7}{|c|}{ camada $80-100 \mathrm{~cm}$} \\
\hline Abril & 11,5 & 10,3 & 7,3 & 8,7 & 7,9 & $9,1 \mathrm{a}$ & 18,8 \\
\hline Julho & 7,0 & 8,3 & 6,3 & 7,3 & 7,0 & $7,2 \mathrm{~b}$ & \\
\hline Média & $9,2 \mathrm{~A}$ & $9,3 \mathrm{~A}$ & $6,8 \mathrm{~B}$ & $8,0 \mathrm{AB}$ & $7,4 \mathrm{AB}$ & & \\
\hline$C V(\%)^{(3)}$ & 20,7 & & & & & & \\
\hline \multicolumn{8}{|c|}{$\begin{array}{l}\text { (1) A (água }+100 \% \text { de } \mathrm{N}) \text {; E1 (efluente }+0 \% \text { de } \mathrm{N}), \mathrm{E} 2 \text { (efluente }+33 \% \text { de } \mathrm{N}) \text {; E3 (efluente+66 \% } \\
\text { de } \mathrm{N}) \text {, E4 (efluente }+100 \% \text { de } \mathrm{N}) \\
\text { (2) } \\
\text { coeficiente de variação para os tratamentos }(\mathrm{A}, \mathrm{E} 1, \mathrm{E} 2, \mathrm{E} 3, \mathrm{E} 4) ; \\
\text { (3) coeficiente de variação para as épocas (abril e julho); } \\
\text { (4) letras iguais maiúsculas nas linhas e minúsculas nas colunas não diferem estatisticamente pelo } \\
\text { teste de Tukey }(\mathrm{P}<0,05) \text {. }\end{array}$} \\
\hline
\end{tabular}

Nenhuma diferença foi observada entre os tratamentos A e E4, onde os volumes de irrigação e os teores de $\mathrm{Na}$ adicionados ao solo foram equivalentes. Hayes et al. (1990) verificaram que, apesar das concentrações de Ca e Mg terem sido maiores no efluente, como ocorreu no presente estudo, nenhuma diferença estatística foi 
observada para os teores de $\mathrm{Ca}+\mathrm{Mg}$ em solo irrigado com água e efluente. Porém, aumentos de teores de $\mathrm{Ca}$ em solos irrigados com efluente e decréscimo em irrigação com água, têm sido observados. Para $\mathrm{Mg}$, maiores decréscimos têm sido observados mediante irrigação com água (Jonhs \& McConchie, 1994).

\section{Alumínio}

O teor de Al aumentou em profundidade (camada 20-100 cm) durante o período experimental (Tabela 15), fato coerente com a redução de $\mathrm{pH}$ do solo verificada, em geral, a partir da profundidade de 10-20 cm (Tabela 10).

Efeitos de tratamento somente não foram observados para a camada $10-20 \mathrm{~cm}$ do solo. Na camada superficial $(0-10 \mathrm{~cm})$ nenhuma diferença foi observada entre os tratamentos com efluente e o tratamento A, porém E3 diferiu de E1. Na camada de 20-40 cm E2 e E3 diferiram dos demais tratamentos e ainda conferiram as maiores médias. Para a camada de 40-60 cm o tratamento E2 foi diferente de A e de E1. Na camada 60-80 cm E2 e E4 foram diferentes de A e de E1 sendo que E3 também diferiu de E1. Entre os tratamentos com efluente E4 diferiu de E1.

Do mesmo modo que para diferença entre teores de Al com o tempo na

área experimental, as diferenças observadas entre os tratamentos têm importante relação com os valores de pH observados (Tabela 10). De um modo geral, verifica-se que os maiores teores de Al foram obtidos nos tratamentos E2, E3 e E4, que também conferiram os menores valores de $\mathrm{pH}$ do solo. Igual relação pode ser feita entre os menores teores de $\mathrm{Al}$ observados nos tratamentos $\mathrm{A}$ e E1 e os maiores valores de $\mathrm{pH}$ obtidos nesses tratamentos. 
Tabela 15. Teor de Al trocável $\left(\mathrm{mmol}_{\mathrm{c}} \mathrm{L}^{-1}\right)$ no solo após irrigação com água ou efluente de esgoto nos meses de abril e julho de 2003

\begin{tabular}{|c|c|c|c|c|c|c|c|}
\hline \multirow{2}{*}{ Época } & \multicolumn{7}{|c|}{ Tratamento $^{(1)}$} \\
\hline & A & E1 & E2 & E3 & E4 & Média & $C V(\%)^{(2)}$ \\
\hline & \multicolumn{7}{|c|}{ camada $0-10 \mathrm{~cm}$} \\
\hline Abril & 1,18 & 0,48 & 1,08 & 1,33 & 0,95 & $1,00 \mathrm{a}^{(3)}$ & 63,4 \\
\hline Julho & 0,13 & 0,58 & 1,08 & 1,68 & 1,10 & $0,91 \mathrm{a}$ & \\
\hline Média & $0,65 \mathrm{AB}^{(3)}$ & $0,53 \mathrm{~B}$ & $1,08 \mathrm{AB}$ & $1,50 \mathrm{~A}$ & $1,03 \mathrm{AB}$ & & \\
\hline \multirow[t]{2}{*}{$C V(\%)^{(3)}$} & 60,0 & & & & & & \\
\hline & \multicolumn{7}{|c|}{ camada $10-20 \mathrm{~cm}$} \\
\hline Abril & 0,75 & 0,93 & 1,15 & 1,45 & 0,63 & $0,98 \mathrm{a}$ & 65,4 \\
\hline Julho & 0,78 & 0,58 & 1,98 & 2,33 & 1,10 & $1,35 \mathrm{a}$ & \\
\hline Média & $0,76 \mathrm{~A}$ & $0,75 \mathrm{~A}$ & $1,56 \mathrm{~A}$ & $1,90 \mathrm{~A}$ & $0,86 \mathrm{~A}$ & & \\
\hline \multirow[t]{2}{*}{$C V(\%)^{(3)}$} & 47,4 & & & & & & \\
\hline & \multicolumn{7}{|c|}{ camada $20-40 \mathrm{~cm}$} \\
\hline Abril & 2,20 & 2,65 & 4,35 & 4,60 & 2,38 & $3,24 \mathrm{~b}$ & 30,6 \\
\hline Julho & 3,80 & 3,90 & 7,83 & 7,53 & 5,45 & $5,70 \mathrm{a}$ & \\
\hline Média & $3,00 \mathrm{~B}$ & $3,28 \mathrm{~B}$ & $6,10 \mathrm{~A}$ & $6,06 \mathrm{~A}$ & $3,91 \mathrm{~B}$ & & \\
\hline \multirow[t]{2}{*}{$C V(\%)^{(3)}$} & 36,3 & & & & & & \\
\hline & \multicolumn{7}{|c|}{ camada $40-60 \mathrm{~cm}$} \\
\hline Abril & 4,00 & 5,38 & 6,38 & 5,95 & 5,38 & $5,41 \mathrm{~b}$ & 22,8 \\
\hline Julho & 5,60 & 5,13 & 9,43 & 7,23 & 7,63 & $7,00 \mathrm{a}$ & \\
\hline Média & $4,79 \mathrm{~B}$ & $5,25 \mathrm{~B}$ & $7,90 \mathrm{~A}$ & $6,60 \mathrm{AB}$ & $6,50 \mathrm{AB}$ & & \\
\hline \multirow[t]{2}{*}{$C V(\%)^{(3)}$} & 34,6 & & & & & & \\
\hline & \multicolumn{7}{|c|}{ camada $60-80 \mathrm{~cm}$} \\
\hline Abril & 3,78 & 4,73 & 6,40 & 5,63 & 5,60 & $5,23 \mathrm{~b}$ & 16,7 \\
\hline Julho & 6,68 & 4,60 & 8,90 & 8,05 & 8,52 & $7,35 \mathrm{a}$ & \\
\hline Média & $5,23 \mathrm{BC}$ & $4,66 \mathrm{C}$ & $7,65 \mathrm{~A}$ & $6,84 \mathrm{AB}$ & $7,06 \mathrm{~A}$ & & \\
\hline \multirow[t]{2}{*}{$C V(\%)^{(3)}$} & 33,7 & & & & & & \\
\hline & \multicolumn{7}{|c|}{ camada $80-100 \mathrm{~cm}$} \\
\hline Abril & 3,95 & 4,03 & 6,48 & 4,95 & 5,75 & $5,03 \mathrm{~b}$ & 25,6 \\
\hline Julho & 6,55 & 5,13 & 7,10 & 6,23 & 8,83 & $6,77 \mathrm{a}$ & \\
\hline Média & $5,25 \mathrm{AB}$ & $4,58 \mathrm{~B}$ & $6,79 \mathrm{AB}$ & $5,60 \mathrm{AB}$ & $7,30 \mathrm{~A}$ & & \\
\hline$C V(\%)^{(3)}$ & 33,1 & & & & & & \\
\hline \multicolumn{8}{|c|}{$\begin{array}{l}\text { A (água }+100 \% \text { de } \mathrm{N}) \text {; E1 (efluente }+0 \% \text { de } \mathrm{N}), \mathrm{E} 2 \text { (efluente }+33 \% \text { de N); E3 (efluente }+66 \% \\
\text { de N), E4 (efluente }+100 \% \text { de } \mathrm{N}) \\
\text { (2) coeficiente de variação para os tratamentos }(\mathrm{A}, \mathrm{E} 1, \mathrm{E} 2, \mathrm{E} 3, \mathrm{E} 4) ; \\
\text { (3) coeficiente de variação para as épocas (abril e julho); } \\
\text { (4) letras iguais maiúsculas nas linhas e minúsculas nas colunas não diferem estatisticamente pelo } \\
\text { teste de Tukey }(\mathrm{P}<0,05) \text {. }\end{array}$} \\
\hline
\end{tabular}

\section{Saturação por bases (V)}

O valor V diminuiu na camada $20-100 \mathrm{~cm}$ do solo com o tempo em toda área experimental (Tabela 16). Esta redução acompanhou a redução de pH (Tabela 10) e 
o aumento dos teores de $\mathrm{Na}$ e $\mathrm{Al}$ (Tabelas 12 e 15). Os cátions $\mathrm{Na}$ e Al podem ter substituído cátions no complexo de troca, uma vez que o teor de $\mathrm{Al}$ e o percentual de $\mathrm{Na}$ no complexo de troca (PST) aumentaram em profundidade (Tabelas 15 e 17).

Tabela 16. Saturação por bases do solo $(\mathrm{V}, \%)^{(1)}$ após irrigação com água ou efluente de esgoto nos meses de abril e julho de 2003

\begin{tabular}{|c|c|c|c|c|c|c|c|}
\hline \multirow{2}{*}{ Época } & \multicolumn{7}{|c|}{ Tratamento $^{(1)}$} \\
\hline & A & E1 & E2 & E3 & E4 & Média & $C V(\%)^{(2)}$ \\
\hline & \multicolumn{7}{|c|}{ camada $0-10 \mathrm{~cm}$} \\
\hline Abril & 56,87 & 60,76 & 52,21 & 48,84 & 54,64 & $54,66 \mathrm{a}^{(4)}$ & 8,5 \\
\hline Julho & 56,11 & 51,29 & 55,11 & 46,24 & 54,46 & $52,64 \mathrm{a}$ & \\
\hline Média & $56,49 \mathrm{~A}^{(4)}$ & $56,03 \mathrm{~A}$ & $53,66 \mathrm{AB}$ & $47,54 \mathrm{~B}$ & $54,55 \mathrm{~A}$ & & \\
\hline \multirow[t]{2}{*}{$C V(\%)^{(3)}$} & 7,0 & & & & & & \\
\hline & \multicolumn{7}{|c|}{ camada $10-20 \mathrm{~cm}$} \\
\hline Abril & 55,77 & 57,56 & 50,72 & 49,33 & 52,87 & $53,25 \mathrm{a}$ & 8,7 \\
\hline Julho & 56,64 & 49,91 & 46,10 & 46,43 & 50,40 & $49,90 \mathrm{~b}$ & \\
\hline Média & $56,21 \mathrm{~A}$ & $53,73 \mathrm{AB}$ & $48,41 \mathrm{~B}$ & $47,88 \mathrm{~B}$ & $51,63 \mathrm{AB}$ & & \\
\hline \multirow[t]{2}{*}{$C V(\%)^{(3)}$} & 7,8 & & & & & & \\
\hline & \multicolumn{7}{|c|}{ camada $20-40 \mathrm{~cm}$} \\
\hline Abril & 48,07 & 51,39 & 37,58 & 39,73 & 46,86 & $44,70 \mathrm{a}$ & 12,1 \\
\hline Julho & 36,77 & 40,35 & 30,59 & 30,11 & 35,67 & $34,70 \mathrm{~b}$ & \\
\hline Média & $42,42 \mathrm{~A}$ & $45,87 \mathrm{~A}$ & $34,08 \mathrm{~B}$ & $34,92 \mathrm{~B}$ & $41,27 \mathrm{AB}$ & & \\
\hline \multirow[t]{2}{*}{$C V(\%)^{(3)}$} & 12,2 & & & & & & \\
\hline & \multicolumn{7}{|c|}{ camada $40-60 \mathrm{~cm}$} \\
\hline Abril & 45,87 & 39,67 & 31,00 & 34,06 & 36,01 & $37,32 \mathrm{a}$ & 13,0 \\
\hline Julho & 32,97 & 38,61 & 27,80 & 29,98 & 31,93 & $32,26 \mathrm{~b}$ & \\
\hline Média & $39,42 \mathrm{~A}$ & $39,14 \mathrm{~A}$ & $29,40 \mathrm{~B}$ & $32,02 \mathrm{~B}$ & $33,97 \mathrm{AB}$ & & \\
\hline \multirow[t]{2}{*}{$C V(\%)^{(3)}$} & 12,7 & & & & & & \\
\hline & \multicolumn{7}{|c|}{ camada $60-80 \mathrm{~cm}$} \\
\hline Abril & 42,38 & 40,06 & 32,68 & 34,00 & 34,90 & $36,80 \mathrm{a}$ & 16,7 \\
\hline Julho & 31,25 & 38,80 & 27,29 & 29,76 & 30,55 & $31,53 \mathrm{~b}$ & \\
\hline Média & $36,81 \mathrm{AB}$ & $39,43 \mathrm{~A}$ & $29,98 \mathrm{~B}$ & $31,88 \mathrm{AB}$ & $32,72 \mathrm{AB}$ & & \\
\hline \multirow[t]{2}{*}{$C V(\%)^{(3)}$} & 18,6 & & & & & & \\
\hline & \multicolumn{7}{|c|}{ camada $80-100 \mathrm{~cm}$} \\
\hline Abril & 42,52 & 39,23 & 29,61 & 36,42 & 30,28 & $35,61 \mathrm{a}$ & 15,7 \\
\hline Julho & 26,21 & 35,17 & 24,41 & 27,17 & 26,24 & $27,84 \mathrm{~b}$ & \\
\hline Média & $34,37 \mathrm{AB}$ & $37,19 \mathrm{~A}$ & $27,01 \mathrm{~B}$ & $31,80 \mathrm{AB}$ & $28,26 \mathrm{~B}$ & & \\
\hline$C V(\%)^{(3)}$ & 16,7 & & & & & & \\
\hline $\begin{array}{l}\text { (1) A (água + } \\
\text { de N), E4 } \\
\text { (2) coeficiente } \\
\text { (3) coeficiente } \\
\text { (4) letras iguai }\end{array}$ & $\begin{array}{l}0 \% \text { de } \mathrm{N}) \\
\text { fluente+100 } \\
\text { e variação } \\
\text { e variação } \\
\text { maiúsculas }\end{array}$ & $\begin{array}{l}\text { E1 (efluente } \\
\% \text { de } \mathrm{N} \text { ) } \\
\text { oara os trata } \\
\text { ara as époc } \\
\text { nas linhas e }\end{array}$ & $\begin{array}{l}+0 \% \text { de } \mathrm{N}) \\
\text { mentos }(\mathrm{A}, \\
\text { as (abril e ju } \\
\text { minúsculas }\end{array}$ & $\begin{array}{l}\text { E2 (efluen } \\
\text { 1, E2, E3, } \\
\text { lho); } \\
\text { nas colunas }\end{array}$ & $\begin{array}{l}\text { e+33\% de } \\
\text { E4); } \\
\text { não diferem }\end{array}$ & N); E3 (eflu & ente $+66 \%$ \\
\hline
\end{tabular}


Considerando os efeitos de tratamentos, diferenças significativas foram observadas para médias de valores de $\mathrm{V}$ entre épocas em todas as camadas estudadas (Tabela 16). Na camada 0-10 cm, E3 diferiu de A e de E1, enquanto que, na camada 10-20 cm, E2 e E3 diferiram de A, sendo que nenhuma diferença foi observada entre os tratamentos com efluente. Nas camadas 20-40 e 40-60 cm, E2 e E3 diferiram de A e de E1. Nas camadas $60-80$ e $80-100 \mathrm{~cm}$ os tratamentos com efluente não diferiram de $\mathrm{A}$, porém, entre os tratamentos com efluente, E2 diferiu de E1 na camada $60-80 \mathrm{~cm}$ enquanto E2 e E4 diferiram de E1.

De um modo geral, nota-se uma tendência para todas as camadas dos menores valores de $\mathrm{V}$ terem ocorrido nos tratamentos E2 e E3. Apesar das diferenças não terem uma importância prática relevante entre todos os tratamentos, acredita-se que a tendência mencionada foi devido ao aumento dos teores de $\mathrm{Al}$ nos mesmos tratamentos (Tabela 15). Nos efeitos de tratamento, nota-se que nenhuma diferença significativa foi observada entre os tratamentos A e E4, onde os volumes de irrigação e a fertilização nitrogenada foram equivalentes, ou seja, a irrigação com água e efluente proporcionaram efeitos iguais sobre a saturação por bases do solo.

\subsubsection{Percentual de sódio trocável (PST)}

Aumento dos valores de PST com o tempo, independentemente dos tratamentos, foram observados até a profundidade de $80 \mathrm{~cm}$, no entanto, para a camada 0-10 cm, esse aumento foi evidenciado para cada tratamento (Tabela 17).

O aumento dos valores de PST com o tempo indica a tendência de sodificação do solo em toda a área experimental. Aumentos de PST têm sido observados na literatura tanto para irrigação com água ou efluente (Falkiner \& Smith, 1997; Balks et al., 1998). O aumento do PST foi devido à sodicidade e principalmente aos altos valores de RAS que as fontes de irrigação apresentaram (Tabela 4), valores esses que conferiram tanto à água como ao efluente, graus de restrição "severo" (Tabela 5) para uso na irrigação conforme Ayers \& Westcot (1985). 
Tabela 17. Percentual de sódio trocável (PST, \%) ${ }^{(1)}$ no solo após irrigação com água ou efluente de esgoto nos meses de abril e julho de 2003

\begin{tabular}{|c|c|c|c|c|c|c|c|}
\hline \multirow{2}{*}{ Época } & \multicolumn{7}{|c|}{ Tratamento $^{(2)}$} \\
\hline & A & E1 & E2 & E3 & E4 & Média & $C V(\%)^{(3)}$ \\
\hline & \multicolumn{7}{|c|}{ camada $0-10 \mathrm{~cm}$} \\
\hline Abril & $3,72 \mathrm{bA}^{(4)}$ & $2,30 \mathrm{bB}$ & $2,27 \mathrm{bB}$ & $2,37 \mathrm{bAB}$ & $2,27 \mathrm{bB}$ & 2,58 & 13,4 \\
\hline Julho & $7,20 \mathrm{aA}$ & $5,56 \mathrm{aB}$ & $7,42 \mathrm{aA}$ & $6,82 \mathrm{aAB}$ & $6,66 \mathrm{aAB}$ & 6,73 & \\
\hline Média & 5,46 & 3,92 & 4,84 & 4,60 & 4,46 & & \\
\hline \multirow[t]{2}{*}{$C V(\%)^{(4)}$} & 13,3 & & & & & & \\
\hline & \multicolumn{7}{|c|}{ camada $10-20 \mathrm{~cm}$} \\
\hline Abril & 2,19 & 1,43 & 1,76 & 1,67 & 1,31 & $1,67 b^{(4)}$ & 25,1 \\
\hline Julho & 4,51 & 3,34 & 4,30 & 4,14 & 3,80 & $4,01 \mathrm{a}$ & \\
\hline Média & $3,35 \mathrm{~A}$ & $2,40 \mathrm{~A}$ & $3,03 \mathrm{~A}$ & $2,91 \mathrm{~A}$ & $2,55 \mathrm{~A}$ & & \\
\hline \multirow[t]{2}{*}{$C V(\%)^{(4)}$} & 9,5 & & & & & & \\
\hline & \multicolumn{7}{|c|}{ camada $20-40 \mathrm{~cm}$} \\
\hline Abril & 1,21 & 0,74 & 1,48 & 0,81 & 0,71 & $1,00 \mathrm{~b}$ & 28,2 \\
\hline Julho & 1,28 & 1,48 & 1,49 & 1,31 & 1,14 & $1,34 \mathrm{a}$ & \\
\hline Média & $1,25 \mathrm{AB}$ & $1,11 \mathrm{AB}$ & $1,48 \mathrm{~A}$ & $1,06 \mathrm{AB}$ & $0,93 \mathrm{~B}$ & & \\
\hline \multirow[t]{2}{*}{$C V(\%)^{(4)}$} & 27,6 & & & & & & \\
\hline & \multicolumn{7}{|c|}{ camada $40-60 \mathrm{~cm}$} \\
\hline Abril & 0,68 & 0,47 & 0,46 & 0,45 & 0,44 & $0,50 \mathrm{~b}$ & 44,0 \\
\hline Julho & 0,76 & 1,03 & 0,84 & 0,66 & 0,72 & $0,80 \mathrm{a}$ & \\
\hline Média & $0,72 \mathrm{~A}$ & $0,75 \mathrm{~A}$ & $0,65 \mathrm{~A}$ & $0,55 \mathrm{~A}$ & $0,58 \mathrm{~A}$ & & \\
\hline \multirow[t]{2}{*}{$C V(\%)^{(4)}$} & 20,0 & & & & & & \\
\hline & \multicolumn{7}{|c|}{ camada $60-80 \mathrm{~cm}$} \\
\hline Abril & 0,58 & 0,43 & 0,83 & 0,45 & 0,43 & $0,54 \mathrm{~b}$ & 35,6 \\
\hline Julho & 0,70 & 0,96 & 0,81 & 0,60 & 0,60 & $0,73 \mathrm{a}$ & \\
\hline Média & $0,64 \mathrm{~A}$ & $0,70 \mathrm{~A}$ & $0,82 \mathrm{~A}$ & $0,53 \mathrm{~A}$ & $0,51 \mathrm{~A}$ & & \\
\hline \multirow[t]{2}{*}{$C V(\%)^{(4)}$} & 23,5 & & & & & & \\
\hline & \multicolumn{7}{|c|}{ camada $80-100 \mathrm{~cm}$} \\
\hline Abril & 0,60 & 0,45 & 0,97 & 0,56 & 0,48 & $0,61 \mathrm{a}$ & 36,5 \\
\hline Julho & 0,55 & 0,80 & 0,74 & 0,55 & 0,64 & $0,66 \mathrm{a}$ & \\
\hline Média & $0,57 \mathrm{~A}$ & $0,63 \mathrm{~A}$ & $0,86 \mathrm{~A}$ & $0,56 \mathrm{~A}$ & $0,56 \mathrm{~A}$ & & \\
\hline$C V(\%)^{(4)}$ & 18,8 & & & & & & \\
\hline \multicolumn{8}{|c|}{ 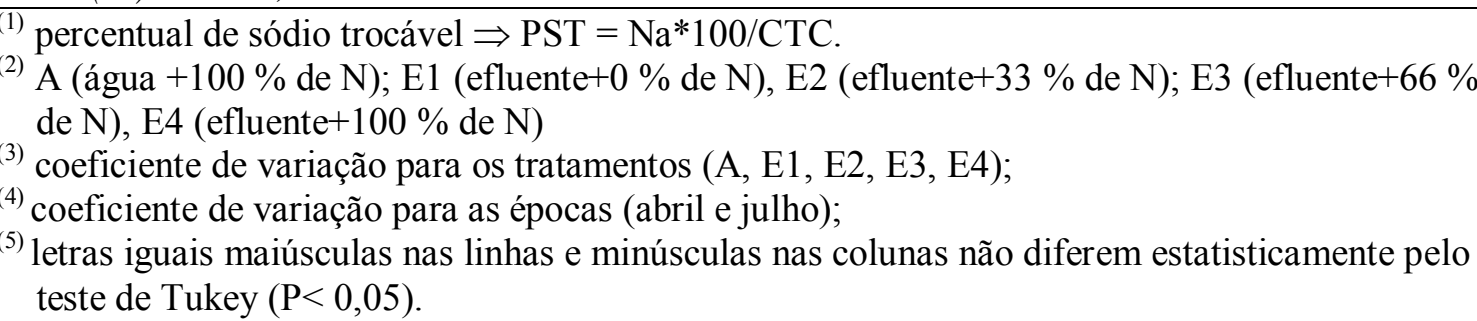 } \\
\hline
\end{tabular}

Efeitos de tratamentos foram observados nas camadas 0-10 e 20-40 cm. No mês de abril os tratamentos E1, E2 e E4 diferiram de A, enquanto que para julho E1 diferiu de A enquanto E2 diferiu de E1 (camada 0-10 cm). Para a camada 20-40 cm, os 
efeitos de tratamento foram observados para médias de PST entre épocas, porém, não foram observadas diferenças significativas entre o tratamento A e os tratamentos com efluente e entre E1 e os demais tratamentos de efluente.

Observa-se que, no mês de abril, a maior média foi verificada para o tratamento A em relação aos tratamentos E1, E2 e E4 (camada 0-10 cm). Este fato indica que maior risco de sodificação foi observado no solo irrigado com água. Balks et al. (1998) também observaram maiores valores de PST em solo irrigado com água, porém, em outros trabalhos, maiores valores de PST têm sido observados em solos irrigados com efluente (Hayes et al., 1990; Falkiner \& Smith, 1997). No presente estudo, apesar de ambas as fontes apresentarem grau de restrição "severo" para uso, maiores valores de RAS foram observados para a água de irrigação, o que certamente refletiu nos maiores valores de PST no mês de abril. Para o mês de julho, observa-se que o valor de PST no tratamento E1 foi numericamente menor que nos demais. Este fato reflete a tendência da menor adição de sódio (menor volume de irrigação) resultar no menor PST do solo com o tempo.

Os maiores valores de PST foram obtidos na superfície do solo (camada 0-10 cm) para o mês de julho $(5,56$ a 7,42 \%) e permaneceram abaixo do limite mínimo de $15 \%$ considerado como indicador de sodicidade do solo (Richards, 1954). No entanto, os valores obtidos podem indicar sodicidade, considerando que, para outros estudos, limites inferiores a $15 \%$ indicam que o solo pode estar sujeito a degradações estruturais (Rengasamy \& Olsson, 1991; Sumner, 1993; Halliwell, 2001).

\subsubsection{Dispersão de argilas}

A dispersão das argilas aumentou com o tempo, independentemente dos tratamentos e em toda a área experimental, exceto para a camada 80-100 cm (Tabela 18). Este fato foi coerente com o aumento dos valores de PST também observados para toda a área (Tabela 17) e indica que tanto a água quanto o efluente contribuíram para a dispersão das argilas do solo. Tendência entre o aumento de PST e a maior dispersão de argilas, em solos irrigados com água ou efluente, também foi observada por Balks et al. (1998). 
Tabela 18. Grau de dispersão $(\mathrm{GD}, \%)^{(1)}$ das argilas nas camadas do solo após irrigação com água ou efluente de esgoto nos meses de abril e julho de 2003

\begin{tabular}{|c|c|c|c|c|c|c|c|}
\hline \multirow{2}{*}{ Época } & \multicolumn{7}{|c|}{ Tratamento $^{(2)}$} \\
\hline & A & E1 & E2 & E3 & E4 & Média & $C V(\%)^{(3)}$ \\
\hline & \multicolumn{7}{|c|}{ camada $0-10 \mathrm{~cm}$} \\
\hline Abril & 11,63 & 23,30 & 14,30 & 11,22 & 13,97 & $14,88 b^{(5)}$ & 22,8 \\
\hline Julho & 27,57 & 29,20 & 28,89 & 27,68 & 23,60 & $27,40 \mathrm{a}$ & \\
\hline Média & $19,60 \mathrm{AB}^{(5)}$ & $26,25 \mathrm{~A}$ & $21,59 \mathrm{AB}$ & $19,45 \mathrm{AB}$ & $18,79 \mathrm{~B}$ & & \\
\hline \multirow[t]{2}{*}{$C V(\%)^{(4)}$} & 28,0 & & & & & & \\
\hline & & \multicolumn{5}{|c|}{ camada $10-20 \mathrm{~cm}$} & - \\
\hline Abril & 13,86 & 21,65 & 11,54 & 10,22 & 9,31 & $13,31 \mathrm{~b}$ & 49,0 \\
\hline Julho & 19,53 & 21,74 & 19,72 & 19,27 & 19,80 & $20,01 \mathrm{a}$ & \\
\hline Média & $16,70 \mathrm{~A}$ & $21,70 \mathrm{~A}$ & $15,63 \mathrm{~A}$ & $14,74 \mathrm{~A}$ & $14,56 \mathrm{~A}$ & & \\
\hline \multirow{2}{*}{$C V(\%)^{(4)}$} & 35,2 & & & & & & \\
\hline & \multicolumn{7}{|c|}{ camada $20-40 \mathrm{~cm}$} \\
\hline Abril & 19,57 & 14,38 & 7,20 & 12,63 & 11,72 & $13,10 \mathrm{~b}$ & 38,8 \\
\hline Julho & 29,98 & 20,55 & 22,18 & 13,15 & 18,78 & $20,93 \mathrm{a}$ & \\
\hline Média & $24,77 \mathrm{~A}$ & $17,46 \mathrm{AB}$ & $14,69 \mathrm{AB}$ & $12,89 \mathrm{~B}$ & $15,25 \mathrm{AB}$ & & \\
\hline \multirow[t]{2}{*}{$C V(\%)^{(4)}$} & 26,1 & & & & & & \\
\hline & \multicolumn{7}{|c|}{ camada $40-60 \mathrm{~cm}$} \\
\hline Abril & 15,02 & 17,60 & 12,31 & 11,74 & 6,53 & $12,64 b$ & 40,0 \\
\hline Julho & 26,92 & 22,63 & 14,68 & 18,85 & 13,43 & $19,30 \mathrm{a}$ & \\
\hline Média & $20,98 \mathrm{~A}$ & $20,11 \mathrm{~A}$ & $13,50 \mathrm{AB}$ & $15,30 \mathrm{AB}$ & $9,98 \mathrm{~B}$ & & \\
\hline \multirow[t]{2}{*}{$C V(\%)^{(4)}$} & 29,0 & & & & & & \\
\hline & \multicolumn{7}{|c|}{ camada $60-80 \mathrm{~cm}$} \\
\hline Abril & 20,45 & 15,13 & 7,94 & 10,69 & 8,62 & $12,56 \mathrm{~b}$ & 23,1 \\
\hline Julho & 21,12 & 17,22 & 19,03 & 13,80 & 15,06 & $17,24 \mathrm{a}$ & \\
\hline Média & $20,78 \mathrm{~A}$ & $16,17 \mathrm{AB}$ & $13,48 \mathrm{~B}$ & $12,24 \mathrm{~B}$ & $11,83 \mathrm{~B}$ & & \\
\hline \multirow[t]{2}{*}{$C V(\%)^{(4)}$} & 52,3 & & & & & & \\
\hline & \multicolumn{7}{|c|}{ camada $80-100 \mathrm{~cm}$} \\
\hline Abril & 7,50 & 3,97 & 2,76 & 3,82 & 3,13 & $4,23 \mathrm{a}$ & 103,9 \\
\hline Julho & 12,94 & 5,43 & 2,16 & 4,92 & 2,50 & $5,60 \mathrm{a}$ & \\
\hline Média & $10,21 \mathrm{~A}$ & $4,70 \mathrm{~A}$ & $2,46 \mathrm{~A}$ & $4,37 \mathrm{~A}$ & $2,81 \mathrm{~A}$ & & \\
\hline$C V(\%)^{(4)}$ & 115,0 & & & & & & \\
\hline \multicolumn{8}{|c|}{$\begin{array}{l}\text { A (água }+100 \% \text { de } \mathrm{N}) \text {; E1 (efluente }+0 \% \text { de } \mathrm{N}) \text {, E2 (efluente }+33 \% \text { de } \mathrm{N}) \text {; E3 (efluente }+66 \% \\
\text { de } \mathrm{N}) \text {, E4 (efluente }+100 \% \text { de } \mathrm{N}) \\
\text { (2) } \\
\text { grau de dispersão de argilas } \Rightarrow \mathrm{GD}=\mathrm{ADA} * 100 / \text { argila total); } \\
\text { (3) coeficiente de variação para os tratamentos }(\mathrm{A}, \mathrm{E} 1, \mathrm{E} 2, \mathrm{E} 3, \mathrm{E} 4) ; \\
\text { (4) } \text { coeficiente de variação para as épocas (abril e julho); } \\
\text { (5) } \text { letras iguais maiúsculas nas linhas e minúsculas nas colunas não diferem estatisticamente pelo } \\
\text { teste de Tukey }(\mathrm{P}<0,05) \text {. }\end{array}$} \\
\hline
\end{tabular}

Nota-se ainda que o aumento da dispersão foi mais pronunciado com o tempo na camada $0-10 \mathrm{~cm}$, o que foi coerente ao maior aumento de PST nesta mesma camada (Tabela 17). Verificou-se ainda que mesmo em baixos valores de PST, entre 20 
e $80 \mathrm{~cm}$ do solo, ocorreu dispersão das argilas. Estudos têm considerado que a sodicidade em solos não é evidenciada abaixo de certos níveis de PST, mas em fato, a dispersão de argilas é comum em valores de PST próximos de zero, quando a concentração eletrolítica da solução é suficientemente baixa (Sumner, 1993).

Foram observados efeitos de tratamento nas camadas 0-10, 20-40, 40-60 e 60-80 cm. Na camada 0-10 cm, os tratamentos com efluente não diferiram do tratamento A, porém, dentre os tratamentos com efluente, E4 diferiu de E1. Para a camada de 20-40 cm o tratamento E3 diferiu de A sendo que os tratamentos com efluente não diferiram entre si. Na camada 40-60 cm, E4 diferiu de A e de E1, enquanto que, na camada 60-80 cm, os tratamentos E2, E3 e E4 diferiram de A e nenhuma diferença foi observada entre os tratamentos com efluente.

Nas camadas entre 40 e $80 \mathrm{~cm}$ o tratamento A resultou em maior dispersão de argilas do que o tratamento E4, o que está de acordo com os maiores valores de RAS apresentados para a água durante o período estudado (Tabela 4).

Nas camadas abaixo de $40 \mathrm{~cm}$, parece ter havido tendência em ocorrer maior dispersão na presença de menores teores de $\mathrm{Al}$ (Tabelas 15 e 18). O alumínio tem efeito na floculação de argilas sendo expressivo em solos sódicos ácidos (Rengasamy \& Olsson, 1993).

Acredita-se que os efeitos de tratamento poderiam ser mais bem entendidos para todas as camadas num maior período de irrigação. Considera-se ainda que muitos fatores têm relação com a dispersão das argilas no solo. A dispersão de argilas tem sido negativamente correlacionada com o conteúdo de matéria orgânica no solo, no entanto, Nelson et al. (1999) observaram que a matéria orgânica pode prevenir ou aumentar a dispersão. Sumner (1993) descreveu a preferência de íons bivalentes em se ligarem à matéria orgânica com consequente enriquecimento das partículas de argila com sódio aumentando a dispersão das argilas. 


\subsection{Efeito da irrigação com efluente de esgoto e com água sobre a solução do solo}

\subsection{1 pH, condutividade elétrica (CE) e alcalinidade como bicarbonatos $\left(\mathrm{HCO}_{3}^{-}\right)$ pH}

O processo de acidificação da solução do solo foi verificado na área experimental, independentemente dos tratamentos, exceto para as camadas 0-10 e 20-40 cm (Tabela 19). Os efeitos de tratamento foram obtidos apenas na camada $0-10 \mathrm{~cm}$, onde E3 diferiu de A e, dentre os tratamentos com efluente, E2, E3 e E4 diferiram de E1. Nesta camada observou-se a tendência dos tratamentos A e E1 apresentarem maiores valores de $\mathrm{pH}$ em relação aos demais tratamentos com efluente o que também foi observado para os valores de $\mathrm{pH}$ do solo na camada $0-10 \mathrm{~cm}$.

Nos efeitos de tratamento, nota-se que nenhuma diferença significativa foi observada entre os tratamentos A e E4, onde os volumes de irrigação e a fertilização nitrogenada foram equivalentes, ou seja, a irrigação com água e efluente proporcionaram efeitos iguais sobre os valores de $\mathrm{pH}$ da solução do solo.

Os valores de pH da solução do solo em todas as camadas e em todos os tratamentos foram maiores que os obtidos para o solo ( $\mathrm{pH}$ em solução $\mathrm{CaCl}_{2}$ ). A solução de $\mathrm{CaCl}_{2}$ utilizada para a determinação dos valores de $\mathrm{pH}$ do solo teve efeito nos menores valores de $\mathrm{pH}$ devido à acidificação promovida pelo Ca. Takachi \& Pavan (1995), em estudo do efeito da natureza do cátion na acidez da solução do solo, verificaram que o $\mathrm{Ca}$ apresentou maior efeito na acidez em relação a $\mathrm{Mg}, \mathrm{K}$ e $\mathrm{Na}$.

Os valores de $\mathrm{pH}$ da solução do solo foram maiores em superfície, porém não superaram o limite mínimo de 8,5 , para condutividade elétrica menor que $4 \mathrm{dS} \mathrm{m}^{-1}$, estabelecido como indicador de sodicidade do solo, segundo classificação descrita em Richards (1954). De acordo com esta classificação, valores de pH menores que 8,5 indicariam sodicidade somente se os valores de condutividade elétrica permanecessem abaixo de $4 \mathrm{dS} \mathrm{m}^{-1}$, o que não ocorreu no presente estudo (Tabela 19). Entretanto, com 
base na classificação descrita em Rengasamy \& Olsson (1991), os valores de pH da solução do solo permaneceram na faixa de 6,0 a 8,0 considerada para "solos sódicos neutros", porém permaneceram muito próximos do limite de 6 , abaixo do qual o solo seria considerado como "solo sódico ácido".

Tabela 19. Valores de pH da solução do solo após irrigação com água ou efluente de esgoto nos meses de abril e julho de 2003

\begin{tabular}{|c|c|c|c|c|c|c|c|}
\hline \multirow{2}{*}{ Época } & \multicolumn{7}{|c|}{ Tratamento $^{(1)}$} \\
\hline & A & E1 & E2 & E3 & E4 & Média & $C V(\%)^{(2)}$ \\
\hline & \multicolumn{7}{|c|}{ camada $0-10 \mathrm{~cm}$} \\
\hline Abril & 6,53 & 6,65 & 6,15 & 5,81 & 6,14 & $6,26 \mathrm{a}^{(4)}$ & 5,7 \\
\hline Julho & 6,55 & 6,84 & 6,04 & 6,02 & 6,14 & $6,32 \mathrm{a}$ & \\
\hline Média & $6,54 \mathrm{AB}^{(4)}$ & $6,75 \mathrm{~A}$ & $6,10 \mathrm{BC}$ & $5,91 \mathrm{C}$ & $6,14 \mathrm{BC}$ & & \\
\hline \multirow{2}{*}{$C V(\%)^{(3)}$} & 7,3 & & & & & & \\
\hline & \multicolumn{7}{|c|}{ camada $10-20 \mathrm{~cm}$} \\
\hline Abril & 6,37 & 6,45 & 6,10 & 6,15 & 6,12 & $6,23 \mathrm{a}$ & 7,5 \\
\hline Julho & 6,31 & 6,18 & 5,33 & 5,34 & 5,67 & $5,76 \mathrm{~b}$ & \\
\hline Média & $6,34 \mathrm{~A}$ & $6,31 \mathrm{~A}$ & $5,71 \mathrm{~A}$ & $5,74 \mathrm{~A}$ & $5,90 \mathrm{~A}$ & & \\
\hline \multirow[t]{2}{*}{$C V(\%)^{(3)}$} & 9,5 & & & & & & \\
\hline & \multicolumn{7}{|c|}{ camada $20-40 \mathrm{~cm}$} \\
\hline Abril & 5,54 & 5,82 & 5,39 & 5,31 & 5,35 & $5,48 \mathrm{a}$ & 9,7 \\
\hline Julho & 5,74 & 5,552 & 4,77 & 4,68 & 5,03 & $5,15 \mathrm{a}$ & \\
\hline Média & $5,64 \mathrm{~A}$ & $5,67 \mathrm{~A}$ & $5,08 \mathrm{~A}$ & $5,00 \mathrm{~A}$ & $5,19 \mathrm{~A}$ & & \\
\hline \multirow[t]{2}{*}{$C V(\%)^{(3)}$} & 9,6 & & & & & & \\
\hline & \multicolumn{7}{|c|}{ camada $40-60 \mathrm{~cm}$} \\
\hline Abril & 5,60 & 5,53 & 5,33 & 5,50 & 5,63 & $5,52 \mathrm{a}$ & 8,2 \\
\hline Julho & 5,59 & 5,44 & 4,81 & 4,94 & 4,77 & $5,11 \mathrm{~b}$ & \\
\hline Média & $5,59 \mathrm{~A}$ & $5,49 \mathrm{~A}$ & $5,07 \mathrm{~A}$ & $5,22 \mathrm{~A}$ & $5,20 \mathrm{~A}$ & & \\
\hline \multirow[t]{2}{*}{$C V(\%)^{(3)}$} & 9,1 & & & & & & \\
\hline & \multicolumn{7}{|c|}{ camada $60-80 \mathrm{~cm}$} \\
\hline Abril & 5,96 & 6,03 & 5,80 & 5,48 & 5,63 & $5,78 \mathrm{a}$ & 7,1 \\
\hline Julho & 5,20 & 5,43 & 5,14 & 5,32 & 4,91 & $5,20 \mathrm{~b}$ & \\
\hline Média & $5,58 \mathrm{~A}$ & $5,73 \mathrm{~A}$ & $5,47 \mathrm{~A}$ & $5,40 \mathrm{~A}$ & $5,27 \mathrm{~A}$ & & \\
\hline \multirow[t]{2}{*}{$C V(\%)^{(3)}$} & 8,1 & & & & & & \\
\hline & \multicolumn{7}{|c|}{ camada $80-100 \mathrm{~cm}$} \\
\hline Abril & 5,86 & 5,83 & 5,42 & 5,51 & 5,87 & $5,70 \mathrm{a}$ & 8,0 \\
\hline Julho & 5,54 & 5,54 & 5,18 & 5,17 & 5,07 & $5,30 \mathrm{~b}$ & \\
\hline Média & $5,70 \mathrm{~A}$ & $5,68 \mathrm{~A}$ & $5,30 \mathrm{~A}$ & $5,34 \mathrm{~A}$ & $5,47 \mathrm{~A}$ & & \\
\hline$C V(\%)^{(3)}$ & 6,2 & & & & & & \\
\hline \multicolumn{8}{|c|}{$\begin{array}{l}\text { (1) A (água }+100 \% \text { de } \mathrm{N}) \text {; E1 (efluente }+0 \% \text { de } \mathrm{N}) \text {, E2 (efluente }+33 \% \text { de } \mathrm{N}) \text {; E3 (efluente+66 \% } \\
\text { de } \mathrm{N}) \text {, E4 (efluente }+100 \% \text { de } \mathrm{N}) \\
\text { (2) } \\
\text { coeficiente de variação para os tratamentos }(\mathrm{A}, \mathrm{E} 1, \mathrm{E} 2, \mathrm{E} 3, \mathrm{E} 4) ; \\
\text { (3) coeficiente de variação para as épocas (abril e julho); } \\
\text { (4) } \text { letras iguais maiúsculas nas linhas e minúsculas nas colunas não diferem estatisticamente pelo } \\
\text { teste de Tukey }(\mathrm{P}<0,05) \text {. }\end{array}$} \\
\hline
\end{tabular}


Com base nas características do solo estudado (Tabela 8), a descrição de solos sódicos ácidos, por Rengasamy \& Olsson (1991), é a que mais se aproxima. Segundo os autores, solos sódicos ácidos são característicos de regiões de alta precipitação, onde cátions como $\mathrm{Ca}^{+2}$ e $\mathrm{Mg}^{+2}$ são lixiviados e suas concentrações na solução do solo são baixas. São solos altamente intemperizados apresentando baixa capacidade de troca de cátions.

\section{Condutividade elétrica (CE)}

Aumento dos valores de CE da solução do solo foram observados com o tempo até os $20 \mathrm{~cm}$ de profundidade do solo, sendo que o aumento de $\mathrm{CE}$ foi evidenciado em cada um dos tratamentos empregados (Tabela 20). Estudos têm evidenciado aumentos de CE tanto em solos irrigados com água como em solos irrigados com efluente (Falkiner \& Smith, 1997; Johns \& McConchie, 1994).

$\mathrm{O}$ aumento de $\mathrm{CE}$ observado na camada $0-10 \mathrm{~cm}$ pode ser atribuído, não somente à adição de sais via água de irrigação e efluente, mas também devido à fertilização mineral realizada em todas as parcelas (Tabela 3). Apesar desse aumento, o nível de salinidade não resultou em risco para o rendimento do capim-Tifton 85 . Segundo Marschner (1995) reduções de rendimento em capins Bermuda (Cynodon dactylon) somente seriam observadas se a condutividade da solução do solo (extrato de saturação) permanecesse acima do valor $6,9 \mathrm{dS} \mathrm{m}^{-1}$.

Efeitos de tratamento sobre a CE foram observados apenas no mês de julho na camada 0-10 cm, onde o tratamento E2 diferiu dos demais conferindo a maior média. A maior CE da solução sob o tratamento E2 reflete a tendência da menor lixiviação de sais ocorrer no solo que recebeu menores volumes de irrigação.

De modo geral, não foram observadas diferenças de efeito sobre a salinidade do solo irrigado com água ou efluente. No entanto, maiores aumentos de salinidade em solos irrigados com efluente têm sido observados em experimentos de longa duração ou em climas áridos e semi-áridos (Hayes et al., 1990; Nakshabandi et al., 1996; Smith et al., 1996). 


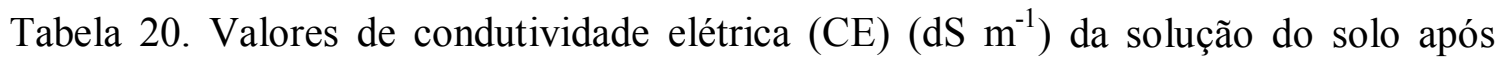
irrigação com água ou efluente de esgoto nos meses de abril e julho de 2003

\begin{tabular}{|c|c|c|c|c|c|c|c|}
\hline \multirow{2}{*}{ Época } & \multicolumn{7}{|c|}{ Tratamento $^{(1)}$} \\
\hline & A & E1 & E2 & E3 & E4 & Média & $C V(\%)^{(2)}$ \\
\hline & \multicolumn{7}{|c|}{ camada $0-10 \mathrm{~cm}$} \\
\hline Abril & $0,34 \mathrm{bA}$ & $0,34 \mathrm{bA}$ & $0,34 \mathrm{bA}$ & $0,29 \mathrm{bA}$ & $0,32 \mathrm{bA}$ & 0,32 & 10,0 \\
\hline Julho & $0,70 \mathrm{aB}^{(3)}$ & $0,74 \mathrm{aB}$ & $0,88 \mathrm{aA}$ & $0,65 \mathrm{aB}$ & $0,70 \mathrm{aB}$ & 0,73 & \\
\hline Média & 0,51 & 0,54 & 0,61 & 0,47 & 0,51 & & \\
\hline \multirow{2}{*}{$C V(\%)^{(3)}$} & 10,7 & & & & & & \\
\hline & \multicolumn{7}{|c|}{ camada $10-20 \mathrm{~cm}$} \\
\hline Abril & 0,28 & 0,29 & 0,30 & 0,27 & 0,33 & $0,29 b^{(3)}$ & 24,8 \\
\hline Julho & 0,55 & 0,74 & 0,64 & 0,55 & 0,68 & $0,63 \mathrm{a}$ & \\
\hline Média & $0,42 \mathrm{~A}$ & $0,51 \mathrm{~A}$ & $0,47 \mathrm{~A}$ & $0,41 \mathrm{~A}$ & $0,50 \mathrm{~A}$ & & \\
\hline \multirow[t]{2}{*}{$C V(\%)^{(3)}$} & 15,6 & & & & & & \\
\hline & \multicolumn{7}{|c|}{ camada $20-40 \mathrm{~cm}$} \\
\hline Abril & 0,25 & 0,23 & 0,27 & 0,20 & 0,24 & $0,24 \mathrm{a}$ & 31,1 \\
\hline Julho & 0,25 & 0,25 & 0,23 & 0,21 & 0,19 & $0,22 \mathrm{a}$ & \\
\hline Média & $0,25 \mathrm{~A}$ & $0,24 \mathrm{~A}$ & $0,25 \mathrm{~A}$ & $0,20 \mathrm{~A}$ & $0,21 \mathrm{~A}$ & & \\
\hline \multirow[t]{2}{*}{$C V(\%)^{(3)}$} & 30,3 & & & & & & \\
\hline & \multicolumn{7}{|c|}{ camada $40-60 \mathrm{~cm}$} \\
\hline Abril & 0,17 & 0,10 & 0,10 & 0,10 & 0,09 & $0,11 \mathrm{a}$ & 85,0 \\
\hline Julho & 0,16 & 0,13 & 0,26 & 0,10 & 0,12 & $0,15 \mathrm{a}$ & \\
\hline Média & $0,16 \mathrm{~A}$ & $0,11 \mathrm{~A}$ & $0,18 \mathrm{~A}$ & $0,10 \mathrm{~A}$ & $1,10 \mathrm{~A}$ & & \\
\hline \multirow[t]{2}{*}{$C V(\%)^{(3)}$} & 65,8 & & & & & & \\
\hline & \multicolumn{7}{|c|}{ camada $60-80 \mathrm{~cm}$} \\
\hline Abril & 0,15 & 0,06 & 0,07 & 0,05 & 0,05 & $0,07 \mathrm{a}$ & 89,2 \\
\hline Julho & 0,07 & 0,06 & 0,06 & 0,05 & 0,11 & $0,07 \mathrm{a}$ & \\
\hline Média & $0,11 \mathrm{~A}$ & $0,06 \mathrm{~A}$ & $0,07 \mathrm{~A}$ & $0,05 \mathrm{~A}$ & $0,08 \mathrm{~A}$ & & \\
\hline \multirow[t]{2}{*}{$C V(\%)^{(3)}$} & 54,7 & & & & & & \\
\hline & \multicolumn{7}{|c|}{ camada $80-100 \mathrm{~cm}$} \\
\hline Abril & 0,09 & 0,05 & 0,07 & 0,05 & 0,05 & $0,06 \mathrm{a}$ & 36,6 \\
\hline Julho & 0,07 & 0,05 & 0,06 & 0,05 & 0,07 & $0,06 \mathrm{a}$ & \\
\hline Média & $0,08 \mathrm{~A}$ & $0,05 \mathrm{~A}$ & $0,06 \mathrm{~A}$ & $0,05 \mathrm{~A}$ & $0,06 \mathrm{~A}$ & & \\
\hline$C V(\%)^{(3)}$ & 43,4 & & & & & & \\
\hline $\begin{array}{l}\text { (1) A (água + } \\
\text { de N), E4 } \\
\text { (2) coeficiente } \\
\text { (3) coeficiente } \\
\text { (4) letras iguai }\end{array}$ & $\begin{array}{l}0 \% \text { de } \mathrm{N}) \\
\text { fluente+ } 100 \\
\text { le variação } \\
\text { le variação } \\
\text { maiúsculas }\end{array}$ & $\begin{array}{l}1 \text { (efluent } \\
\% \text { de N) } \\
\text { ra os trat } \\
\text { ra as épo } \\
\text { as linhas }\end{array}$ & $\begin{array}{l}0 \% \text { de } \mathrm{N} \\
\text { entos }(\mathrm{A} \text {, } \\
\text { (abril e j } \\
\text { ninúscula }\end{array}$ & $\begin{array}{l}\text { E2 (eflues } \\
\text { 1, E2, E3, } \\
\text { ho); } \\
\text { las coluna }\end{array}$ & $\begin{array}{l}\mathrm{e}+33 \% \mathrm{de} \\
4) ;\end{array}$ & N); E3 (efl & $\begin{array}{l}\text { ente }+66 \% \\
\text { nente pelo }\end{array}$ \\
\hline
\end{tabular}

Considerando os baixos valores de $\mathrm{CE}$ da solução do solo $\left(<1 \mathrm{dS} \mathrm{m}^{-1}\right) \mathrm{em}$ todas as camadas e tratamentos, o solo poderia ser classificado como "sódico" de acordo com classificação de solos sódicos descrita em Richards (1954). Entretanto, os valores 
de PST (Tabela 17) e de $\mathrm{pH}$ (Tabela 19) permaneceram abaixo do limite para tal classificação.

\section{Alcalinidade como $\mathrm{HCO}_{3}{ }^{-}$}

A alcalinidade da solução do solo como $\mathrm{HCO}_{3}{ }^{-}$reduziu nas camadas 10-20, 60-80 e 80-100 cm e em toda a área experimental (Tabela 21).

Tabela 21. Alcalinidade da solução do solo como bicarbonato $\left(\mathrm{HCO}_{3}{ }^{-}\right)\left(\mathrm{mmol}_{\mathrm{c}} \mathrm{L}^{-1}\right)$ após irrigação com água ou efluente de esgoto nos meses de abril e julho de 2003

\begin{tabular}{|c|c|c|c|c|c|c|c|}
\hline \multirow{2}{*}{ Época } & \multicolumn{7}{|c|}{ Tratamento $^{(1)}$} \\
\hline & A & E1 & E2 & E3 & E4 & Média & $C V(\%)^{(2)}$ \\
\hline & \multicolumn{7}{|c|}{ camada $0-10 \mathrm{~cm}$} \\
\hline Abril & 0,50 & 0,69 & 0,63 & 0,50 & 0,44 & $0,55 \mathrm{a}^{(3)}$ & \multirow[t]{4}{*}{102,1} \\
\hline Julho & 0,41 & 0,69 & 0,38 & 0,50 & 0,44 & $0,48 \mathrm{a}$ & \\
\hline Média & $0,46 \mathrm{~A}^{(3)}$ & $0,69 \mathrm{~A}$ & $0,50 \mathrm{~A}$ & $0,50 \mathrm{~A}$ & $0,44 \mathrm{~A}$ & & \\
\hline \multirow[t]{2}{*}{$C V(\%)^{(3)}$} & 57,4 & & & & & & \\
\hline & \multicolumn{7}{|c|}{ camada $10-20 \mathrm{~cm}$} \\
\hline Abril & 0,50 & 0,63 & 0,69 & 0,44 & 0,31 & $0,51 \mathrm{a}$ & \multirow[t]{3}{*}{84,6} \\
\hline Julho & 0,38 & 0,25 & 0,00 & 0,31 & 0,19 & $0,23 \mathrm{~b}$ & \\
\hline Média & $0,44 \mathrm{~A}$ & $0,44 \mathrm{~A}$ & $0,34 \mathrm{~A}$ & $0,38 \mathrm{~A}$ & $0,25 \mathrm{~A}$ & & \\
\hline \multirow{2}{*}{$C V(\%)^{(3)}$} & 48,1 & & & & & & \\
\hline & \multicolumn{7}{|c|}{ camada $20-40 \mathrm{~cm}$} \\
\hline Abril & 0,56 & 0,50 & 0,50 & 0,46 & 0,50 & $0,51 \mathrm{a}$ & \multirow[t]{2}{*}{67,1} \\
\hline Julho & 0,75 & 0,38 & 0,00 & 0,31 & 0,19 & $0,33 \mathrm{a}$ & \\
\hline Média & $0,66 \mathrm{~A}$ & $0,44 \mathrm{~A}$ & $0,25 \mathrm{~A}$ & $0,39 \mathrm{~A}$ & $0,34 \mathrm{~A}$ & & \\
\hline \multirow[t]{2}{*}{$C V(\%)^{(3)}$} & 66,0 & & & & & & \\
\hline & \multicolumn{7}{|c|}{ camada $40-60 \mathrm{~cm}$} \\
\hline Abril & 0,44 & 0,37 & 0,50 & 0,34 & 0,50 & $0,43 \mathrm{a}$ & 80,7 \\
\hline Julho & 0,75 & 0,13 & 0,13 & 0,00 & 0,50 & $0,30 \mathrm{a}$ & \\
\hline Média & $0,60 \mathrm{~A}$ & $0,25 \mathrm{~A}$ & $0,31 \mathrm{~A}$ & $0,17 \mathrm{~A}$ & $0,50 \mathrm{~A}$ & & \\
\hline \multirow[t]{2}{*}{$C V(\%)^{(3)}$} & 63,1 & & & & & & \\
\hline & \multicolumn{7}{|c|}{ camada $60-80 \mathrm{~cm}$} \\
\hline Abril & 0,88 & 0,44 & 0,50 & 0,40 & 0,38 & $0,52 \mathrm{a}$ & \multirow[t]{2}{*}{65,4} \\
\hline Julho & 0,56 & 0,19 & 0,13 & 0,33 & 0,25 & $0,29 \mathrm{~b}$ & \\
\hline Média & $0,72 \mathrm{~A}$ & $0,31 \mathrm{~A}$ & $0,31 \mathrm{~A}$ & $0,36 \mathrm{~A}$ & $0,31 \mathrm{~A}$ & & \\
\hline \multirow[t]{2}{*}{$C V(\%)^{(3)}$} & 69,3 & & & & & & \\
\hline & \multicolumn{7}{|c|}{ camada $80-100 \mathrm{~cm}$} \\
\hline Abril & 0,38 & 0,56 & 0,63 & 0,41 & 0,38 & $0,47 \mathrm{a}$ & 72,4 \\
\hline Julho & 0,19 & 0,00 & 0,00 & 0,25 & 0,38 & $0,16 \mathrm{~b}$ & \\
\hline Média & $0,28 \mathrm{~A}$ & $0,28 \mathrm{~A}$ & $0,31 \mathrm{~A}$ & $0,33 \mathrm{~A}$ & $0,38 \mathrm{~A}$ & & \\
\hline$C V(\%)^{(3)}$ & \multicolumn{7}{|c|}{68,9} \\
\hline \multicolumn{8}{|c|}{$\begin{array}{l}\text { (1) A (água }+100 \% \text { de N); E1 (efluente }+0 \% \text { de } \mathrm{N}) \text {, E2 (efluente }+33 \% \text { de N); E3 (efluente }+66 \% \text { de N), } \\
\text { E4 (efluente }+100 \% \text { de } \mathrm{N}) \\
\text { coeficiente de variação para os tratamentos (A, E1, E2, E3, E4); } \\
\text { (3) coeficiente de variação para as épocas (abril e julho); } \\
\text { (4) letras iguais maiúsculas nas linhas e minúsculas nas colunas não diferem estatisticamente pelo teste de } \\
\text { Tukey }(\mathrm{P}<0,05) \text {. }\end{array}$} \\
\hline
\end{tabular}


A redução da alcalinidade na área experimental acompanhou a redução do pH tanto do solo (Tabela 10) quanto da solução do solo (Tabela 20). Considerando os efeitos sobre uma possível sodicidade, a redução da alcalinidade é favorável, pois reduz o efeito do sódio no solo (Richards, 1954; Feigin et al., 1991).

\subsubsection{Concentrações de sódio, potássio, cálcio+magnésio e alumínio}

\section{Sódio}

Os teores de $\mathrm{Na}$ na solução do solo aumentaram com o tempo em toda a área experimental, nas camadas 0-10 e 10-20 cm, independentemente dos tratamentos (Tabela 22).

O aumento com o tempo acompanhou os aumentos de PST (Tabela 17) e dos teores de Na no solo (Tabela 12). Abaixo dos $20 \mathrm{~cm}$ de profundidade, aumentos de concentração de $\mathrm{Na}$ não foram constatadas, ao contrário do que foi observado para valores de PST e Na trocável. No entanto, o aumento das concentrações de Na no solo e na solução do solo provavelmente ocorreram devido adição desse elemento via água e efluente.

Efeitos de tratamentos sobre as concentrações de $\mathrm{Na}$ foram evidenciados para médias de concentração de $\mathrm{Na}$ entre épocas para todos os tratamentos, nas camadas 0-10 e 20-40 cm. Para ambas as camadas, os tratamentos com efluentes não diferiram de A do mesmo modo que E1 não diferiu dos demais tratamentos com efluente. Portanto, efeitos iguais sobre a concentração de $\mathrm{Na}$ na solução do solo foram verificadas após irrigação com água e com efluente. 
Tabela 22. Concentração de Na na solução do solo $\left(\mathrm{mmol}_{\mathrm{c}} \mathrm{L}^{-1}\right)$ após irrigação com água ou efluente de esgoto nos meses de abril e julho de 2003

\begin{tabular}{|c|c|c|c|c|c|c|c|}
\hline \multirow{2}{*}{ Época } & \multicolumn{7}{|c|}{ Tratamento $^{(1)}$} \\
\hline & A & E1 & E2 & E3 & E4 & Média & $C V(\%)^{(2)}$ \\
\hline & \multicolumn{7}{|c|}{ camada $0-10 \mathrm{~cm}$} \\
\hline Abril & 2,70 & 2,32 & 2,41 & 2,18 & 1,81 & $2,28 b^{(3)}$ & 13,2 \\
\hline Julho & 4,28 & 4,22 & 5,07 & 3,97 & 4,20 & $4,35 \mathrm{a}$ & \\
\hline Média & $3,49 \mathrm{AB}^{(3)}$ & $3,27 \mathrm{AB}$ & $3,74 \mathrm{~A}$ & $3,07 \mathrm{AB}$ & $3,01 \mathrm{~B}$ & & \\
\hline \multirow[t]{2}{*}{$C V(\%)^{(3)}$} & 9,1 & & & & & & \\
\hline & \multicolumn{7}{|c|}{ camada $10-20 \mathrm{~cm}$} \\
\hline Abril & 2,07 & 1,52 & 2,21 & 1,87 & 1,44 & $1,82 \mathrm{~b}$ & 26,2 \\
\hline Julho & 2,32 & 2,43 & 2,93 & 2,45 & 2,47 & $2,52 \mathrm{a}$ & \\
\hline Média & $2,20 \mathrm{~A}$ & $1,97 \mathrm{~A}$ & $2,57 \mathrm{~A}$ & $2,16 \mathrm{~A}$ & $1,95 \mathrm{~A}$ & & \\
\hline \multirow[t]{2}{*}{$C V(\%)^{(3)}$} & 16,3 & & & & & & \\
\hline & \multicolumn{7}{|c|}{ camada $20-40 \mathrm{~cm}$} \\
\hline Abril & 1,03 & 0,31 & 1,26 & 0,66 & 0,33 & $0,72 \mathrm{a}$ & 54,5 \\
\hline Julho & 0,53 & 0,63 & 0,72 & 0,62 & 0,41 & $0,58 \mathrm{a}$ & \\
\hline Média & $0,78 \mathrm{AB}$ & $0,47 \mathrm{AB}$ & $0,99 \mathrm{~A}$ & $0,64 \mathrm{AB}$ & $0,37 \mathrm{~B}$ & & \\
\hline \multirow[t]{2}{*}{$C V(\%)^{(3)}$} & 55,6 & & & & & & \\
\hline & \multicolumn{7}{|c|}{ camada $40-60 \mathrm{~cm}$} \\
\hline Abril & 0,31 & 0,16 & 0,65 & 0,21 & 0,17 & $0,30 \mathrm{a}$ & 64,5 \\
\hline Julho & 0,26 & 0,35 & 0,31 & 0,26 & 0,26 & $0,29 \mathrm{a}$ & \\
\hline Média & $0,28 \mathrm{~A}$ & $0,25 \mathrm{~A}$ & $0,48 \mathrm{~A}$ & $0,24 \mathrm{~A}$ & $0,22 \mathrm{~A}$ & & \\
\hline \multirow[t]{2}{*}{$C V(\%)^{(3)}$} & 62,0 & & & & & & \\
\hline & \multicolumn{7}{|c|}{ camada $60-80 \mathrm{~cm}$} \\
\hline Abril & 0,20 & 0,16 & 0,22 & 0,13 & 0,15 & $0,17 \mathrm{a}$ & 99,2 \\
\hline Julho & 0,15 & 0,25 & 0,26 & 0,16 & 0,41 & $0,25 \mathrm{a}$ & \\
\hline Média & $0,17 \mathrm{~A}$ & $0,20 \mathrm{~A}$ & $0,24 \mathrm{~A}$ & $0,15 \mathrm{~A}$ & $0,28 \mathrm{~A}$ & & \\
\hline \multirow[t]{2}{*}{$C V(\%)^{(3)}$} & 55,5 & & & & & & \\
\hline & \multicolumn{7}{|c|}{ camada $80-100 \mathrm{~cm}$} \\
\hline Abril & 0,31 & 0,13 & 0,23 & 0,17 & 0,14 & $0,19 \mathrm{a}$ & 62,0 \\
\hline Julho & 0,13 & 0,15 & 0,23 & 0,13 & 0,10 & $0,15 \mathrm{a}$ & \\
\hline Média & $0,22 \mathrm{~A}$ & $0,14 \mathrm{~A}$ & $0,23 \mathrm{~A}$ & $0,15 \mathrm{~A}$ & $0,12 \mathrm{~A}$ & & \\
\hline$C V(\%)^{(3)}$ & 37,0 & & & & & & \\
\hline $\begin{array}{l}\text { (1) A (água +1 } \\
\text { de N), E4 } \\
\text { (2) coeficiente } \\
\text { (3) coeficiente } \\
\text { (4) letras iguai }\end{array}$ & $\begin{array}{l}00 \% \text { de } \mathrm{N}) ; \mathrm{H} \\
\text { efluente+100 } \\
\text { de variação } \mathrm{p} \\
\text { de variação } \mathrm{p} \\
\text { maiúsculas } 1\end{array}$ & $\begin{array}{l}\text { 1 (efluente } \\
\% \text { de } \mathrm{N} \text { ) } \\
\text { ara os trata } \\
\text { ara as époc } \\
\text { tas linhas e }\end{array}$ & $\begin{array}{l}0 \% \text { de } \mathrm{N} \\
\text { entos }(\mathrm{A} \text {, } \\
\text { (abril e j } \\
\text { ninúscula }\end{array}$ & $\begin{array}{l}\text { E2 (eflue } \\
\text { 1, E2, E3 } \\
\text { lho); } \\
\text { nas coluna }\end{array}$ & $\begin{array}{l}+33 \% \mathrm{de} \\
4)\end{array}$ & N); E3 (eflu & ente+66\% \\
\hline
\end{tabular}

\section{Potássio}

A concentração de $\mathrm{K}$ na solução do solo aumentou com o tempo na camada 0-10 cm de toda a área experimental (Tabela 23). Esse aumento acompanhou o 
aumento do teor de $\mathrm{K}$ trocável na mesma camada do solo (Tabela 13). O aumento da concentração na solução foi atribuído à fertilização mineral potássica realizada em área total durante o período experimental (Tabela 3).

Tabela 23. Concentração de $\mathrm{K}$ na solução do solo $\left(\mathrm{mmol}_{\mathrm{c}} \mathrm{L}^{-1}\right)$ após irrigação com água ou efluente de esgoto nos meses de abril e julho de 2003

\begin{tabular}{|c|c|c|c|c|c|c|c|}
\hline \multirow{2}{*}{ Época } & \multicolumn{7}{|c|}{ Tratamento $^{(1)}$} \\
\hline & A & E1 & E2 & E3 & E4 & Média & $C V(\%)^{(2)}$ \\
\hline & \multicolumn{7}{|c|}{ camada $0-10 \mathrm{~cm}$} \\
\hline Abril & 0,38 & 0,41 & 0,49 & 0,37 & 0,41 & $0,41 \mathrm{~b}^{(4)}$ & 20,9 \\
\hline Julho & 0,57 & 0,77 & 0,83 & 0,58 & 0,52 & $0,65 \mathrm{a}$ & \\
\hline Média & $0,48 \mathrm{~B}^{(4)}$ & $0,59 \mathrm{AB}$ & $0,66 \mathrm{~A}$ & $0,47 \mathrm{~B}$ & $0,46 \mathrm{~B}$ & & \\
\hline \multirow[t]{2}{*}{$C V(\%)^{(3)}$} & 23,8 & & & & & & \\
\hline & \multicolumn{7}{|c|}{ camada $10-20 \mathrm{~cm}$} \\
\hline Abril & 0,20 & 0,20 & 0,25 & 0,19 & 0,28 & $0,22 \mathrm{a}$ & 30,6 \\
\hline Julho & 0,16 & 0,24 & 0,20 & 0,15 & 0,23 & $0,19 \mathrm{a}$ & \\
\hline Média & $0,18 \mathrm{~A}$ & $0,22 \mathrm{~A}$ & $0,22 \mathrm{~A}$ & $0,17 \mathrm{~A}$ & $0,25 \mathrm{~A}$ & & \\
\hline \multirow[t]{2}{*}{$C V(\%)^{(3)}$} & 24,0 & & & & & & \\
\hline & \multicolumn{7}{|c|}{ camada $20-40 \mathrm{~cm}$} \\
\hline Abril & 0,09 & 0,09 & 0,11 & 0,09 & 0,11 & $0,10 \mathrm{a}$ & 28,6 \\
\hline Julho & 0,08 & 0,08 & 0,09 & 0,07 & 0,06 & $0,08 \mathrm{~b}$ & \\
\hline Média & $0,08 \mathrm{~A}$ & $0,08 \mathrm{~A}$ & $0,10 \mathrm{~A}$ & $0,08 \mathrm{~A}$ & $0,09 \mathrm{~A}$ & & \\
\hline \multirow[t]{2}{*}{$C V(\%)^{(3)}$} & 34,0 & & & & & & \\
\hline & \multicolumn{7}{|c|}{ camada $40-60 \mathrm{~cm}$} \\
\hline Abril & 0,05 & 0,04 & 0,05 & 0,04 & 0,04 & $0,05 \mathrm{a}$ & 27,3 \\
\hline Julho & 0,07 & 0,04 & 0,04 & 0,03 & 0,05 & $0,05 \mathrm{a}$ & \\
\hline Média & $0,06 \mathrm{~A}$ & $0,04 \mathrm{AB}$ & $0,05 \mathrm{AB}$ & $0,04 \mathrm{~B}$ & $0,05 \mathrm{AB}$ & & \\
\hline \multirow[t]{2}{*}{$C V(\%)^{(3)}$} & 31,0 & & & & & & \\
\hline & \multicolumn{7}{|c|}{ camada $60-80 \mathrm{~cm}$} \\
\hline Abril & 0,05 & 0,02 & 0,03 & 0,02 & 0,03 & $0,03 \mathrm{a}$ & 64,8 \\
\hline Julho & 0,03 & 0,02 & 0,03 & 0,02 & 0,04 & $0,03 \mathrm{a}$ & \\
\hline Média & $0,04 \mathrm{~A}$ & $0,02 \mathrm{~A}$ & $0,03 \mathrm{~A}$ & $0,02 \mathrm{~A}$ & $0,03 \mathrm{~A}$ & & \\
\hline \multirow[t]{2}{*}{$C V(\%)^{(3)}$} & 51,3 & & & & & & \\
\hline & \multicolumn{7}{|c|}{ camada $80-100 \mathrm{~cm}$} \\
\hline Abril & 0,05 & 0,02 & 0,04 & 0,04 & 0,03 & $0,04 \mathrm{a}$ & 29,4 \\
\hline Julho & 0,04 & 0,02 & 0,04 & 0,03 & 0,03 & $0,03 \mathrm{a}$ & \\
\hline Média & $0,05 \mathrm{~A}$ & $0,02 \mathrm{C}$ & $0,04 \mathrm{AB}$ & $0,03 \mathrm{ABC}$ & $0,03 \mathrm{BC}$ & & \\
\hline$C V(\%)^{(3)}$ & 48,5 & & & & & & \\
\hline $\begin{array}{l}\text { (1) A (água +1 } \\
\text { de N), E4 } \\
\text { (2) coeficiente } \\
\text { (3) coeficiente } \\
\text { (4) letras iguai }\end{array}$ & $\begin{array}{l}0 \% \text { de } \mathrm{N}) \\
\text { fluente+100 } \\
\text { le variação } \\
\text { e variação } \\
\text { maiúsculas }\end{array}$ & $\begin{array}{l}\text { 1 (efluente } \\
\% \text { de } \mathrm{N} \text { ) } \\
\text { ara os trata } \\
\text { ara as époc } \\
\text { tas linhas e }\end{array}$ & $\begin{array}{l}0 \% \text { de } \mathrm{N} \text { ) } \\
\text { entos }(\mathrm{A} \text {, } \\
\text { (abril e ju } \\
\text { hinúsculas }\end{array}$ & $\begin{array}{l}\text { E2 (efluent } \\
\text { 1ho); E2, E3, } \\
\text { nas colunas }\end{array}$ & $\begin{array}{l}\mathrm{e}+33 \% \mathrm{de} \\
4) ;\end{array}$ & N); E3 (eflu & ente $+66 \%$ \\
\hline
\end{tabular}


Efeitos de tratamento sobre as concentrações de $\mathrm{K}$ na solução do solo foram observados para as camadas 0-10, 40-60 e 80-100 cm. Observa-se que, na camada 0-10 cm, apenas E2 foi diferente de A, enquanto nenhuma diferença foi observada entre E1 e os demais tratamentos de irrigação com efluente. Na camada de 40-60 cm, o tratamento E3 diferiu de A enquanto não foram observadas diferenças entre os tratamentos com efluente.

Nota-se que há uma tendência das maiores concentrações de $\mathrm{K}$ terem ocorrido nos tratamentos E1 e E2. Esta mesma tendência foi observada para os teores de $\mathrm{K}$ no solo até $20 \mathrm{~cm}$ (Tabela 12). Do mesmo modo que para o solo, as maiores concentrações de $\mathrm{K}$ na solução do solo podem estar relacionados a menor lixiviação promovida nesses tratamentos devido aos menores volumes de efluente adicionados. Provavelmente o efeito de maior concentração também tenha sido influenciado pela menor remoção desse elemento pelo capim, tendo em vista os menores acúmulos de massa seca observados (Tabela 26).

\section{Cálcio+Magnésio}

Foi observada redução da concentração de $\mathrm{Ca}+\mathrm{Mg}$ na solução do solo como tempo e em toda a área experimental, nas camadas 20-40 e 80-100 cm. Aumento da concentração foi observada apenas na camada 10-20 cm (Tabela 24).

A redução das concentrações de $\mathrm{Ca}+\mathrm{Mg}$ com o tempo foi coerente com a redução dos teores trocáveis de $\mathrm{Ca}+\mathrm{Mg}$ que ocorreu nas mesmas camadas (Tabela 14). Efeitos de tratamento foram verificados apenas nas camadas 0-10, 40-60 e 80-100 m. Na camada 0-10 cm apenas o tratamento E1 diferiu de A, enquanto E3 e E4 diferiram de E1. Nas camadas 40-60 e 80-100 cm, as maiores concentrações de $\mathrm{Ca}+\mathrm{Mg}$ na solução foram obtidas para o tratamento A. 
Tabela 24. Concentração de $\mathrm{Ca}+\mathrm{Mg}$ no solo $\left(\mathrm{mmol}_{\mathrm{c}} \mathrm{L}^{-1}\right)$ após irrigação com água ou efluente de esgoto nos meses de abril e julho de 2003

\begin{tabular}{|c|c|c|c|c|c|c|c|}
\hline \multirow{2}{*}{ Época } & \multicolumn{7}{|c|}{ Tratamento $^{(1)}$} \\
\hline & A & E1 & E2 & E3 & E4 & Média & $C V(\%)^{(2)}$ \\
\hline & \multicolumn{7}{|c|}{ camada $0-10 \mathrm{~cm}$} \\
\hline Abril & 0,75 & 1,31 & 0,90 & 0,85 & 1,03 & $1,00 \mathrm{a}^{(4)}$ & 26,1 \\
\hline Julho & 0,80 & 1,46 & 1,22 & 0,60 & 0,88 & $1,00 \mathrm{a}$ & \\
\hline Média & $0,77 \mathrm{~B}^{(4)}$ & $1,38 \mathrm{~A}$ & $1,06 \mathrm{AB}$ & $0,72 \mathrm{~B}$ & $0,96 \mathrm{~B}$ & & \\
\hline \multirow[t]{2}{*}{$C V(\%)^{(3)}$} & 26,7 & & & & & & \\
\hline & \multicolumn{7}{|c|}{ camada $10-20 \mathrm{~cm}$} \\
\hline Abril & 1,10 & 1,52 & 1,30 & 1,20 & 1,30 & $1,28 b$ & 45,3 \\
\hline Julho & 1,99 & 2,97 & 1,96 & 1,62 & 2,78 & $2,26 \mathrm{a}$ & \\
\hline Média & $1,54 \mathrm{~A}$ & $2,24 \mathrm{~A}$ & $1,63 \mathrm{~A}$ & $1,41 \mathrm{~A}$ & $2,04 \mathrm{~A}$ & & \\
\hline \multirow[t]{2}{*}{$C V(\%)^{(3)}$} & 27,6 & & & & & & \\
\hline & \multicolumn{7}{|c|}{ camada $20-40 \mathrm{~cm}$} \\
\hline Abril & 1,46 & 1,56 & 1,21 & 1,11 & 1,43 & $1,35 \mathrm{a}$ & 50,7 \\
\hline Julho & 1,38 & 1,09 & 0,70 & 0,69 & 0,80 & $0,93 b$ & \\
\hline Média & $1,42 \mathrm{~A}$ & $1,33 \mathrm{~A}$ & $0,95 \mathrm{~A}$ & $0,90 \mathrm{~A}$ & $1,11 \mathrm{~A}$ & & \\
\hline \multirow[t]{2}{*}{$C V(\%)^{(3)}$} & 48,5 & & & & & & \\
\hline & \multicolumn{7}{|c|}{ camada $40-60 \mathrm{~cm}$} \\
\hline Abril & 0,94 & 0,51 & 0,29 & 0,35 & 0,37 & $0,49 a$ & 55,7 \\
\hline Julho & 0,88 & 0,46 & 0,24 & 0,27 & 0,32 & $0,45 \mathrm{a}$ & \\
\hline Média & $0,91 \mathrm{~A}$ & $0,48 \mathrm{~B}$ & $0,27 \mathrm{~B}$ & $0,31 \mathrm{~B}$ & $0,40 \mathrm{~B}$ & & \\
\hline \multirow[t]{2}{*}{$C V(\%)^{(3)}$} & 90,0 & & & & & & \\
\hline & \multicolumn{7}{|c|}{ camada $60-80 \mathrm{~cm}$} \\
\hline Abril & 1,10 & 0,17 & 0,14 & 0,11 & 0,14 & $0,33 a$ & 228,0 \\
\hline Julho & 0,19 & 0,12 & 0,07 & 0,09 & 0,29 & $0,15 \mathrm{a}$ & \\
\hline Média & $0,65 \mathrm{~A}$ & $0,15 \mathrm{~A}$ & $0,11 \mathrm{~A}$ & $0,10 \mathrm{~A}$ & $0,21 \mathrm{~A}$ & & \\
\hline \multirow[t]{2}{*}{$C V(\%)^{(3)}$} & 170,5 & & & & & & \\
\hline & \multicolumn{7}{|c|}{ camada $80-100 \mathrm{~cm}$} \\
\hline Abril & 0,33 & 0,12 & 0,12 & 0,11 & 0,11 & $0,16 a$ & 28,3 \\
\hline Julho & 0,22 & 0,06 & 0,06 & 0,06 & 0,06 & $0,09 b$ & \\
\hline Média & $0,27 \mathrm{~A}$ & $0,09 \mathrm{~B}$ & $0,09 \mathrm{~B}$ & $0,08 \mathrm{~B}$ & $0,09 \mathrm{~B}$ & & \\
\hline$C V(\%)^{(3)}$ & 146,6 & & & & & & \\
\hline \multicolumn{8}{|c|}{$\begin{array}{l}\text { (1) A (água }+100 \% \text { de } \mathrm{N}) \text {; E1 (efluente }+0 \% \text { de } \mathrm{N}), \mathrm{E} 2 \text { (efluente }+33 \% \text { de } \mathrm{N}) \text {; E3 (efluente+ } 66 \% \\
\text { de } \mathrm{N}) \text {, E4 (efluente }+100 \% \text { de } \mathrm{N}) \\
\text { (2) } \\
\text { coeficiente de variação para os tratamentos }(\mathrm{A}, \mathrm{E} 1, \mathrm{E} 2, \mathrm{E} 3, \mathrm{E} 4) ; \\
{ }^{(3)} \text { coeficiente de variação para as épocas (abril e julho); } \\
{ }^{(4)} \text { letras iguais maiúsculas nas linhas e minúsculas nas colunas não diferem estatisticamente pelo } \\
\text { teste de Tukey }(\mathrm{P}<0,05) \text {. }\end{array}$} \\
\hline
\end{tabular}

\section{Alumínio}

O alumínio não foi detectado em solução pelo método instrumental empregado. Conforme Pavan (1983), há relação entre o Al trocável e a concentração na 
solução do solo, fato que tem sido discutido em muitos trabalhos. No presente trabalho não se observou esta relação, considerando que o Al não foi detectado em solução, ao contrário do que ocorreu para o solo (Tabela 15). Entretanto, os resultados de Al para a solução do solo são coerentes com os valores de $\mathrm{pH}$ mais elevados obtidos para a solução do solo em todas as camadas e tratamentos (Tabela 19). Em valores de pH acima de 5, íons $\mathrm{Al}^{+3}$ se hidrolisam e têm sua solubilidade diminuída (Lindsay, 1979).

\subsubsection{Razão de adsorção de sódio (RAS)}

Os valores de RAS aumentaram em toda a área experimental nas camadas 0-10 e 60-80 cm (Tabela 25). O aumento na camada superficial correspondeu ao aumento de Na na solução do solo (Tabela 22). Para ambas as camadas, também foram observados aumento de $\mathrm{Na}$ trocável (Tabela 12) e de dispersão de argilas com o tempo (Tabela 18).

Efeitos de tratamento foram observados nas camadas 20-40 e 40-60 cm. Na camada de 20-40 cm o tratamento A não diferiu dos tratamentos com efluente e, porém A diferiu de E2 na camada 40-60 cm. Dentre os tratamentos com efluente, em ambas as camadas, E1 não diferiu dos demais tratamentos.

Nota-se que os valores de RAS da solução do solo foram maiores em superfície, em geral superiores a 3 (Tabela 26), principalmente para o mês de julho. De acordo com classificação de solos descrita em Rengasamy \& Olsson (1991), os solos apresentam efeitos de sodicidade em valores de RAS acima de 3. 


\subsection{Efeito da irrigação com efluente de esgoto e com água sobre a produção de massa seca do capim-Tifton 85}

A produção de massa seca do capim-Tifton 85 reduziu nos meses estudados, independentemente dos tratamentos empregados (Tabela 28). Essa redução foi coerente com a estacionalidade de produção de massa seca entre os meses do ano observada para forrageiras. A maior produção de massa seca foi observada para o corte realizado no mês de março, o que refletiu a maior produção do capim durante os meses de verão. A produção foi reduzindo até o mês de julho que refletiu a produção do período mais frio. O gênero Cynodon tem origem na África Tropical (Pedreira et al., 1998), em regiões de baixas latitudes $\left(10^{\circ} \mathrm{N}\right.$ a $18^{\circ} \mathrm{S}$; Quênia, Uganda, Tanzânia e Angola) e apresenta ciclo fotossintético $\mathrm{C}_{4}$, ambas características são típicas de plantas que vegetam bem durante o verão, mas que têm o crescimento sensivelmente reduzido durante o inverno (Corsi \& Martha Júnior, 1998).

Tabela 26. Produção de massa seca $\left(\mathrm{kg} \mathrm{ha}^{-1}\right)$ da parte aérea do capim-Tifton 85 após irrigação com água ou efluente de esgoto nos meses de abril e julho de 2003

\begin{tabular}{|c|c|c|c|c|c|c|c|}
\hline \multirow{2}{*}{ Época } & \multicolumn{7}{|c|}{ Tratamento $^{(1)}$} \\
\hline & A & E1 & E2 & E3 & E4 & Média & $C V(\%)^{(2)}$ \\
\hline Março & 7736 & 5237 & 5721 & 6297 & 7468 & $6492 a^{(4)}$ & 14,3 \\
\hline Maio & 4188 & 3447 & 3441 & 3813 & 4987 & 3975 b & \\
\hline Julho & 3512 & 2446 & 2558 & 3251 & 3381 & $3030 \mathrm{c}$ & \\
\hline Média & $5145 \mathrm{AB}^{(4)}$ & $3710 \mathrm{C}$ & $3907 \mathrm{C}$ & $4454 \mathrm{BC}$ & $5279 \mathrm{~A}$ & & \\
\hline$C V(\%)^{(3)}$ & 11,6 & & & & & & \\
\hline $\begin{array}{l}\text { (1) A (água - } \\
\text { de N), E } \\
\text { (2) coeficien } \\
\text { (3) coeficien } \\
\text { (4) letras igu } \\
\text { teste de }\end{array}$ & $\begin{array}{l}00 \% \text { de } \mathrm{N}) ; \\
\text { efluente }+100 \\
\text { de variação } \mathrm{p} \\
\text { de variação } \mathrm{p} \\
\text { maiúsculas } \\
\text { key }(\mathrm{P}<0,05)\end{array}$ & $\begin{array}{l}\text { (efluent } \\
0 \text { de N) } \\
\text { a os trate } \\
\text { a as époc } \\
\text { s linhase }\end{array}$ & $\begin{array}{l}\text { ientos (A } \\
\text { (março, } \\
\text { ninúscula }\end{array}$ & $\begin{array}{l}\text { 1, E2, E3, } \\
\text { laio e julho } \\
\text { nas coluna }\end{array}$ & 4); & ); E3 (eflu & ente $+66 \%$ \\
\hline
\end{tabular}

Os efeitos de tratamento sobre a produção de massa seca foram observados somente para médias entre as épocas. Essas diferenças são atribuídas à fertilização nitrogenada diferenciada realizada entre os tratamentos, o que resultou na maior necessidade de irrigação. Os tratamentos E1 e E2 diferiram de A enquanto apenas E4 diferiu de E1 e de E3. Os tratamentos E1 e E2 receberam as menores taxas de 
fertilização, refletindo as menores médias em relação ao tratamento A. Dentre os tratamentos com efluente, o tratamento E4, que recebeu a maior taxa de fertilização nitrogenada, apresentou a maior produção de massa seca em relação a E1.

É importante considerar que a produção de massa seca nos tratamentos A e E4 são muito próximas e numericamente maiores do que a dos demais tratamentos em todos os meses, o que, notadamente, refletiu na existência de efeito de tratamentos para médias entre épocas. Considerando a aplicação de volumes praticamente iguais de água e efluente entre A e E4 (Tabela 6) e que a fertilização mineral foi equivalente para esses tratamentos, verifica-se que a irrigação com efluente foi equivalente à irrigação com água em termos de produção de massa seca. No entanto, conclusões sobre a eficiência da irrigação com efluente dependem não somente de estudos relacionados à produção de massa seca, mas também de estudos sobre a nutrição mineral do capim.

\subsection{Síntese}

1. Tanto o efluente quanto a água utilizados para irrigação, apresentaram graus de restrição "severo" quanto aos valores de RAS, porém os maiores valores foram observados para a água de Lins (Tabela 5). Os valores de $\mathrm{pH}$ da água foram mais elevados do que do efluente. A salinidade do efluente foi superior à da água durante o período de irrigação (Tabela 4), mas não resultou em redução do rendimento do capim-Tifton 85 (Tabelas 26 e 7).

2. A acidificação do solo e da solução do solo ocorreu com o tempo na maioria das camadas estudadas, independentemente dos tratamentos de irrigação (Tabelas 10 e 19). Dentre os tratamentos com efluente, a acidificação do solo e da solução foi influenciada pela fertilização nitrogenada (Tabela 3). Os maiores valores de $\mathrm{pH}$ em superfície (camada 0-10 cm) para o tratamento A (água $+100 \%$ de N) podem estar relacionado ao maior valor do $\mathrm{pH}$ da água. $\mathrm{O}$ menor valor do $\mathrm{pH}$ do solo sob o tratamento E4 (efluente $+100 \%$ de $\mathrm{N}$ ), quando comparado ao tratamento A, poderia ser explicado pelo menor valor do $\mathrm{pH}$ do efluente e pela adição de $\mathrm{N}$ via irrigação o que contribui para a acidificação. 
3. O sódio trocável aumentou com o tempo, independentemente dos tratamentos, em praticamente todas as camadas, em decorrência da adição desse elemento via água e efluente. $\mathrm{O}$ aumento em solução foi observado apenas em superfície $(0-20 \mathrm{~cm})$. Apesar de haver uma tendência do tratamento A resultar em maiores teores de sódio trocável no solo, não foram observadas diferenças significativas entre a irrigação com água e com efluente (tratamentos A e E4, respectivamente).

4. O teor de potássio no solo e na solução aumentou com o tempo em superfície (0-10 cm), independentemente dos tratamentos, devido à fertilização mineral potássica realizada em toda a área durante o período de irrigação e à provável adição desse elemento via efluente. Em alguns casos, tanto no solo quanto em solução, observou-se a tendência dos tratamentos E1 (efluente $+0 \%$ de N) e E2 (efluente + $33 \%$ de $\mathrm{N}$ ) apresentarem os maiores teores de $\mathrm{K}$, provavelmente devido aos menores volumes de irrigação adicionados sob esses tratamentos (Tabela 7), o que ocasionou menor lixiviação, e aos menores acúmulos de massa seca pelo capim que pode ter resultado na menor absorção desse elemento (Tabela 26).

5. Não foi possível explicar adequadamente o comportamento dos teores de cálcio+magnésio no solo e na solução do solo. Foram observadas diminuições de teores com o tempo, independentemente dos tratamentos, nas camadas 20-40 cm e 80-100 cm. Em parte, esse fato pode estar relacionado ao aumento do teor de sódio em praticamente todas as camadas (Tabela 12). Não foram observadas variações nos teores de cálcio+magnésio devido aos efeitos de tratamento, conforme ressaltado na comparação entre os tratamentos A e E4.

6. O alumínio trocável aumentou na camada $40-100 \mathrm{~cm}$ durante o período experimental, fato atribuído à redução de $\mathrm{pH}$ do solo ocorrida nessa profundidade (Tabela 10). Os maiores teores de alumínio nos tratamentos E2, E3 (efluente $+66 \%$ de N) e E4 podem ser igualmente explicados pelos menores valores de $\mathrm{pH}$ obtidos nos mesmos tratamentos. Em geral, não foram observados efeitos nos teores de alumínio no solo 
quando comparados os tratamentos com água e com efluente (tratamentos A e E4, respectivamente).

7. A saturação por bases diminuiu com o tempo na camada $20-100 \mathrm{~cm}$ do solo em toda a área, independentemente dos tratamentos (Tabela 16). Esta redução acompanhou a diminuição de $\mathrm{pH}$ do solo e o aumento dos teores de sódio e alumínio trocáveis (Tabelas 10, 12 e 15). Tanto o sódio como o alumínio podem ter substituído cátions no complexo de troca, uma vez que o teor de alumínio e o PST aumentaram em profundidade (Tabelas 15 e 17). Não foram observadas diferenças da irrigação com água e com efluente (tratamentos A e E4) no que diz respeito quanto aos efeitos sobre a saturação por bases do solo.

8. Os valores de PST aumentaram com o tempo em praticamente todas as camadas, independentemente dos tratamentos (Tabela 17), devido as altas concentrações de $\mathrm{Na}$ e aos altos valores de RAS da água e do efluente (Tabela 4). No mês de abril, na camada 0-10 cm, foi verificada maior tendência de sodificação no solo sob irrigação com água, enquanto que no mês de julho, a menor tendência de sodificação foi observada no solo que recebeu menor volume de irrigação e menor adição de sódio (tratamento E1). De um modo geral, os valores de PST obtidos em toda a área, principalmente em superfície, indicam que o solo pode estar sujeito a degradações estruturais.

9. A salinidade do solo aumentou com o tempo em superfície, independentemente dos tratamentos, devido à fertilização mineral e à adição de sais via água e efluente (Tabela 20). Apesar de não ter havido diferença de acúmulo de sais para água (tratamento A) ou efluente (tratamento E4), verificou-se que, em julho, o tratamento E2 conferiu maior salinidade ao solo em superfície, refletindo uma menor lixiviação de sais em decorrência dos menores volumes de irrigação.

10. A dispersão das argilas aumentou com o tempo na área experimental, em praticamente todas as camadas e independentemente dos tratamentos (Tabela 18), o que indica que todos os tratamentos contribuíram para a dispersão das argilas. A 
dispersão foi coerente com o aumento do PST (Tabela 17) e foi observada mesmo em valores de PST abaixo dos considerados na literatura como indicadores de deterioração da estrutura do solo.

11. Os valores de RAS da solução do solo aumentaram em toda a área experimental com o tempo, nas camadas 0-10 e 60-80 cm, independentemente dos tratamentos (Tabela 26). Esse aumento foi coerente ao aumento de $\mathrm{Na}$ em solução na camada 0-10 cm e aos aumentos de Na trocável e dispersão de argilas em ambas as camadas. Não foram observadas diferenças de efeitos da irrigação com água e com efluente sobre os valores de RAS da solução.

12. A produção de massa seca do capim-Tifton 85 diminuiu com o tempo nos meses estudados em toda a área, independentemente dos tratamentos (Tabela 26) devido a estacionalidade de produção observada para forrageiras. A maior produção ocorreu no mês de março (verão) e foi sendo reduzida até o mês de julho (inverno). A irrigação com efluente (tratamento E4) foi equivalente à irrigação com água (tratamento A) na produção de massa seca. As menores produções foram observadas nos tratamentos que receberam menores volumes de irrigação com efluente e menores quantidades de fertilização nitrogenada.

Em geral, os efeitos da irrigação com água e efluente sobre os teores de cátions no solo e na solução do solo foram mais pronunciados e melhor entendidos nas camadas superficiais. 


\section{CONCLUSÕES}

Tanto a água quanto o efluente de esgoto tratado de Lins apresentaram graus de restrição para uso em irrigação, devido aos teores de $\mathrm{Na}$, alcalinidade, e valores de RAS observados. No entanto os valores de RAS da água (28 a 50, média $=40$ ) foram bem superiores aos do efluente $(11$ a 18 , média $=15)$ em todo o período, indicam que, no caso estudado, a irrigação com água representa maior risco de alterações estruturais do solo

A acidificação do solo e da solução ocorreu durante o período estudado após irrigação com água ou com efluente sendo, no entanto, maior sob irrigação com efluente. Aumentos dos teores de alumínio trocável foram verificados devido à acidificação.

De um modo geral, os teores dos elementos estudados não apresentaram diferenças significativas no solo e na solução do solo após irrigação com água ou com efluente. O sódio teve sua concentração aumentada, tanto no solo como na solução do solo e em toda a área experimental, pelo fato de existir em teores elevados tanto na água como no efluente.

A dispersão de argilas ocorreu em toda a área e em praticamente todas as camadas devido ao aumento do PST. O aumento da dispersão com o tempo foi mais pronunciado em superfície o que está de acordo com o maior aumento do PST e da RAS da solução do solo. O efeito sobre a dispersão foi equivalente no solo irrigado com água e com efluente, no entanto, maior dispersão de argilas é esperada no solo irrigado com água por maiores períodos, considerando os maiores valores de RAS apresentados pela água neste estudo. 
O efluente foi eficiente em suprir o capim-Tifton com água, não resultando em prejuízo de acúmulo de massa seca quando comparado ao tratamento de irrigação com água.

A sustentabilidade do uso do efluente de esgoto tratado em agrossistemas depende do manejo adequado da irrigação, monitoramento das características do solo, da solução do solo e da cultura. Como foi observado, o acúmulo de Na no solo é um dos principais entraves para o uso do efluente na irrigação, mesmo em regiões de clima tropical onde há remoção deste elemento devido às altas precipitações, como é o caso de Lins. No entanto, o acúmulo pode ser controlado por meio de práticas agrícolas preconizadas em diversos estudos como, por exemplo, a aplicação de sais de cálcio solúveis como o gesso, e ainda a manutenção dos teores de $\mathrm{Ca}$ e $\mathrm{Mg}$ em níveis adequados no solo. 


\section{REFERÊNCIAS BIBLIOGRÁFICAS}

AGENDA 21: Capítulo 18 - Proteção da qualidade e do abastecimento dos recursos hídricos: aplicação de critérios integrados no desenvolvimento, manejo e uso dos recursos hídricos. http://www.mma.gov.br.

Al-NAKSHABANDI, G.A.; SAQQAR, M.M; SHATANAWI, M.R.; FAYYAD, M. AL-HORANI, H. Some environmental problems associated with the use of treated wastewater for irrigation in Jordan. Agricultural Water Management. v.34, p.81-94, 1997.

AMERICAN PUBLIC HEALTH ASSOCIATION. Standard methods for the examination for water and wastewater. 18.ed. Washington, 1994. 70p.

AYERS, R.S; WESTCOT, D.S. Water quality for agriculture. Rome: FAO, 1985. 174p. (Irrigation and Drainage Paper, 29).

BALKS, M.R.; BOND, W.J.; SMITH, C.J. Effects of sodium accumulation on soil physical properties under an effuent-irrigated plantation. Australian Journal of Soil Research, v.36, p.821-830, 1998.

BOND, W.J. Effluent irrigation - an environmental challenge for soil science. Australian Journal of Soil Research, v.36, p.543-555, 1998.

BOUWER, H.; CHANEY, R.L. Land treatment of wastewater. Advances in Agronomy, v.26, p.133-176, 1974.

BRADY, N.C, WEIL, R.R.; The nature and properties of soils, 12 ed. New Jersey: Prentice Hall, 1999. 881p.

CAMARGO, O.A.; MONIZ, A.C.; JORGE, J.A.; VALADARES, J.M.A.S. Métodos de análise química, mineralógica e física de solos do Instituto Agronômico de Campinas. Campinas: Instituto Agronômico, 1986. 94p. (Boletim Técnico, 106). 
CORSI, M.; MARTHA JÚNIOR, G.B. Manejo de pastagens para produção de carne e leite. In: PEIXOTO, M.A.; MOURA, J.C.; FARIA V.P. (Ed.). Manejo de pastagens de tifton, coastcross e estrela. Piracicaba: FEALQ, 1998. p.55-83.

EMPRESA BRASILEIRA DE PESQUISA AGROPECUÁRIA. Manual de métodos de análises de solo. 2. ed. Rio de Janeiro: Embrapa-CNPS, 1997. 212 p.

EMPRESA BRASILEIRA DE PESQUISA AGROPECUÁRIA. Manual de análises químicas de solos, plantas e fertilizantes. Brasília: Embrapa Solos/Embrapa Informática, Agropecuária/Embrapa, Comunicação para Transferência de Tecnologia, 1999. 370p.

ESCOLA SUPERIOR DE AGRICULTURA “LUIZ DE QUIROZ”. Comissão de Pós-Graduação. Normas para elaboração de dissertações e teses. Piracicaba: ESALQ, 1987.64p.

FALKINER, R.A.; SMITH, C.J. Changes in soils chemistry in effluent-irrigated Pinus radiata and Eucalyptus grandis. Australian Journal of Soil Research, v.35, p.131-147, 1997.

FEIGIN, A.; RAVINA, I.; SHALHEVET, J. Irrigation with treated sewage effluent: management for environmental protection. Berlin: Springer-Verlag, 1991. 224p.

FURLANI, A.M.C. (Eds.). Recomendações de adubação e calagem para o Estado de São Paulo. 2.ed. Campinas: Instituto Agronômico, 1996. p.263-273. (Boletim Técnico, 100).

GRABER, R.D.; GERSTL, Z.; FISCHER, E.; MINGELGRIN, U. Enhanced transport of atrazine under irrigation with effluent. Soil Science Society of America journal. v.59, p.1513-1519, 1995.

HALLIWELL, D.J.; BARLOW, K.M.; NASH, D.M. A review of the effects of wastewater sodium on soil physical properties and their implications for irrigation systems. Australian Journal of Soil Research, v.39, p.1259-1267, 2001.

HAYES, A.R.; MANCINO, C.F.; PEPPER, I.L. Irrigation of turfgrass with secondary sewage effluent: I. Soil and leachate water quality. Agronomy Journal. v.82, p.939-946, 1990. 
HESPANHOL, I. potencial de reuso de água no Brasil-agricultura, indústria, municípios, recarga de aqüíferos. Revista Brasileira de Recursos Hídricos. Porto Alegre, v.7, p.75-95, 2002.

IBRAHIM, L. Caracterização física, química, mineralógica e morfológica de uma seqüência de solos em Lins/SP. Piracicaba, 2002. 86 p. Dissertação (Mestrado)Escola Superior de Agricultura "Luiz de Queiroz”, Universidade de São Paulo.

IRVINE, S.A.; REID, D.J. Field prediction of sodicity in dryland agriculture in Central Queensland, Australia. Australian Journal of Soil Research, v.39, p.1349-1357, 2001.

JOHNS G.G.; McCONCHIE, D.M. Irrigation of bananas with secondary treated sewage effluent. ii. effect on plant nutrients, additional elements and pesticide residues in plants, soil and leachate using drainage lysimeters. Australian Journal of Agriculture Research, v.45, p.1619-1638, 1994.

KOURAA A.; FETHI, F.; FAHDE, A.; LAHLOU, A. QUAZZANI, N. Reuse of urban wastewater treated by a combined stabilisation pond system in Benslimane (Morocco). Urban water. v.4, p.373-378, 2002.

LINDSAY, W.L. Chemical Equilibria in Soils. New York: Wiley, 1979. 449p.

MAAS, E.V. Crop tolerance to saline sprinkling water. Plant and Soil. v.89, p.273-284, 1985.

MAGESAN, G.N.; WILLIAMSON, J.C.; YEATES, G.W.; LLOYD-JONES, A.Rh. Wastewater $\mathrm{C}: \mathrm{N}$ ratio effects on soil hydraulic conductivity and potential mechanisms for recovery. Bioresource Technology. v.71, p.21-27, 2000.

MARSCHNER, H. Mineral nutrition of higher plants Berlin: Academic Press, 1995. 674p.

MAVROGIANOPOULOS, G.; VOGLI, V.; KYRITSIS, S. Use of wastewater as a nutrient solution in a closed gravel hydroponic culture of giant reed (Arundo donax). Bioresource Technology, v. 82, p.103-107, 2002.

MELI, S.; PORTO, M.; BELliGNO, A.; BUFO, S.A.; MAZZATURA, A.; SCOPA, A. Influence of irrigation with lagooned urban wastewater on chemical and 
microbiological soil parameters in a citrus orchard under Mediterranean condition. The Science of the Total Environment. v.285, p.69-77, 2002.

MEURER, E.J. Fundamentos de química do solo. Porto Alegre: Genesis, 2000. p.109-122.

NELSON, P.N. Dispersed clay and organic matter in soil: their nature an associations. Australian Journal of Agriculture Research, v.37, p.289-315, 1999.

ORON, G. Soil as complementary treatment component for simultaneous wastewater disposal and reuse. Water Science \& Technology, v. 34, p.243-252, 1996.

ORTEGA-LARROCEA, M.P.; SIEBE, C.; BÉCARD, G.;MÉNDEZ, I.; WEBSTER, R. Impact of a century of wastewater irrigation on the abundance of arbuscular mycorrhizal spores in the soil of the Mezquital Valley of Mexico. Applied Soil Ecology. v.16, p.149-157, 2001.

PAVAN, M.A. Alumínio em solos ácidos do Paraná: relação entre o alumínio nãotrocável, trocável e solúvel, com o pH, CTC, percentagem de saturação de $\mathrm{Al}$ e matéria orgânica. Revista Brasileira de Ciência do Solo. v.17, p.39-46, 1983.

PEDREIRA, C.G.S.; NUSSIO, L.G.; SILVA, S.C. Condições edafo-climáticas para produção de Cynodon spp. In: PEIXOTO, M.A.; MOURA, J.C.; FARIA V.P. (Ed.). Manejo de pastagens de tifton, coastcross e estrela. Piracicaba: FEALQ, 1998. p.85-113.

PESCOD, M. B. Wastewater treatment and reuse in agriculture. Rome: FAO, 1992. 125. (Irrigação and Drainage Paper, 47).

PIMENTEL-GOMES, F.; GARCIA, H.C. Estatística aplicada a experimentos agronômicos e florestais: exposição com exemplos e orientações para uso de aplicativos. Piracicaba :FEALQ, 2002. p.48-57.

PIVELI, R.P., DORIA, M.C. Condições Operacionais de Sistema de Tratamento de Esgotos por Lagoas de Estabilização em Lins/SP, (compact disc) In: CONGRESSO BRASILEIRO DE ENGENHARIA SANITÁRIA E AMBIENTAL, 22, Joinville, 2003. Anais Joinville: ABES, 2003.

RAIJ, B.van. Fertilidade do solo e adubação. Piracicaba: Potafos, 1991. 343p. 
RAIJ, B.van, GHEYI, H.R.; BATAGLIA, O.C. Determinação da condutividade elétrica e de cátions solúveis em extratos aquosos. In: RAIJ, B.van; ANDRADE, J.C.; CANTARELLA, H.; QUAGGIO, J.A. (Ed.). Análise química para avaliação da fertilidade de solos tropicais. Campinas: Instituto Agronômico, 2001. p.277-285.

RAIJ, B.van; ANDRADE, J.C.; CANTARELlA, H.; QUAGGIO, J.A. (Ed.) Análise química para avaliação da fertilidade de solos tropicais. Campinas: Instituto Agronômico, 2001. 285p.

RENGASAMY, P.; OLSSON, K.A. Irrigation and sodicity. Australian Journal of Agriculture Research, v.31, p.821-837, 1993.

RENGASAMY, P.; OLSSON, K.A. Sodicity and soil structure. Australian Journal of Agriculture Research, v.29, p.935-952, 1991.

RICHARDS, L.A. (Ed). Diagnosis and improvement of saline and alkali soils. Washington, DC: United States Salinity Laboratory Staff, USDA, 1954. 160p. (Agriculture Handbook, 60).

RODRIGUES, L.R.A.; REIS, R.A.; FILHO, C.V.S. Estabelecimento de pastagens de Cynodon. In: PEIXOTO, M.A.; MOURA, J.C.; FARIA V.P. (Eds.). Manejo de pastagens de tifton, coastcross e estrela. Piracicaba: FEALQ, 1998. p.115-128.

SALEM, S.S. Environmental considerations for wastewater reuse in agriculture. Water Science \& Technology, v. 33, p.345-353, 1996.

SCHOFIELD, R.K.; SAMSON, H.R. Flocculation of kaolinite due to the attraction of oppositely charged crystal faces. Discussions of the faraday society. v.18, p.135-145, 1954.

SMITH, C.J.; HOPMANS, P.; COOK, F.J. Accumulation of Cr, $\mathrm{Pb}, \mathrm{Cu}, \mathrm{Ni}, \mathrm{Zn}$ and $\mathrm{Cd}$ in soil following irrigation with treated urban effluent in Australia. Environmental Pollution, v.94, p. 317-323, 1996.

SUMNER, M.E. Sodic soils: new perspectives. Australian Journal of Soil Research, v.31, p.683-750, 1993.

TAKACHI, C.Y.; PAVAN, M.A.; Efeito da natureza e da força iônica do cátiom na acidez da solução do solo. Revista Brasileira de Ciência do Solo. v.19, p.15-18, 1995. 
VAZQUEZ-MONTIEL, O.; HORAN, N. J.; MARA, D. D. Management of domestic wastewater for reuse in irrigation. Water Science \& Technology, v. 33, p.355-362, 1996.

VILELA, D.; ALVIM M.J. Manejo de pastagens do gênero Cynodon: introdução, caracterização e evolução do uso no Brasil. In: PEIXOTO, M.A.; MOURA, J.C.; FARIA V.P. (Ed.). Manejo de pastagens de tifton, coastcross e estrela. Piracicaba: FEALQ, 1998. p.23-54.

WERNER, J.C.; PAULINO, V.T.; CANTARELLA, H.; ANDRADE, N.O.; QUAGGIO, J.A. Forrageiras. In: RAIJ, B.van; CANTARELLA, H.; QUAGGIO, J.A.; FURLANI, A.M.C. (Ed.). Recomendações de adubação e calagem para o Estado de São Paulo. 2.ed. Campinas: Instituto Agronômico, 1996. p.263-273. (Boletim Técnico, 100).

YADAV, R.K.; GOYAL, B.; SHARMA, R.K.; DUBEY, S.K.; MINHAS P.S. Post-irrigation impact of domestic sewage effluent on composition of soils, crops and ground water - a case study. Environment International, v.28, p.481-486, 2002 . 